Carl Beck Papers in Russian \&

East European Studies

Number 1405
Olga E. Glagoleva

Dream and Reality of

Russian Provincial

Young Ladies,

1700-1850

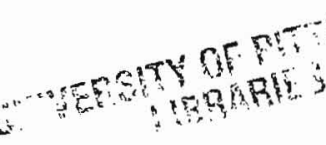

SSURGH MAR I $\triangle 2000$
GIFT \& EXCHANGE MAR I $\triangle 2000$
GIFT \& EXCHANGE 
Olga E. Glagoleva is a Resident Fellow at the Centre for Russian and East European Studies, University of Toronto. She obtained her Ph.D. from the Institute of Russian History, Russian Academy of Science, St. Petersburg in 1987. Her publications include monographs: Working with Russian Archival Documents: A Guide to Modern Handwriting, Document Forms, Language Patterns, and Other Related Topics (1998); Russkaia Provintsial'naia Starina: Ocherki kul'tury i byta Tul'skoi gubernii XVIII pervoi poloviny XIX vv. (1993); Tul'skaia Knizhnaia Starina: Ocherki kul'turnoi zhizni $X V I I I$ - pervoi poloviny XIX vv. (1992); and a number of articles. The history of Russian culture, Russian women's history, and archival studies are among her research interests.

No. 1405, January 2000

(C) 2000 by The Center for Russian and East European Studies, a program of the University Center for International Studies, University of Pittsburgh

ISSN 0889-275X

The Carl Beck Papers

Editors: William Chase, Bob Donnorummo, Ronald H. Linden

Managing Editor: Eileen O'Malley

Cover Design: Mike Savitski

Submissions to The Carl Beck Papers are welcome. Manuscripts must be in English, double-spaced throughout, and less than 100 pages in length. Acceptance is based on anonymous review. Mail submissions to: Editor, The Carl Beck Papers, Center for Russian and East European Studies, 4G-17 Forbes Quadrangle, University of Pittsburgh, Pittsburgh, PA 15260. 


\section{Acknowledgments}

This work is a continuation of my many years' research on Russian provincial history and a part of my ongoing study of women's everyday life in the Russian Provinces in the eighteenth and nineteenth centuries. The first version of this paper originated from my presentation at the conference Private Life in Russia: Medieval Times to Present, University of Michigan, Ann Arbor, MI in 1996. I am grateful to its organizers for their financial support and for the opportunity to discuss my topic in the friendly atmosphere of this conference. I felt especially encouraged by the comments and suggestions made by Jane Burbank, Elise K. Wirtschafter, Natalia Pushkareva, Jeffrey Brooks, Nancy S. Kollmann, Barbara Walker, and Thomas Newlin, and I thank them all.

I would like to cordially thank all members of the Centre for Russian and East European Studies (CREES), University of Toronto, my current scholarly home whose highly intellectual environment and warm, stimulating atmosphere benefit my work and broaden my knowledge. I am particularly indebted to Robert E. Johnson, director, Lynne Viola, Susan Gross Solomon, Peter H. Solomon, Jr., Ronald W. Pruessen, and Wayne E. Dowler for their constant generous support and comments on my ideas and research. Special thanks to Lynne Viola for her careful reading of my manuscript, her continuous advice, and her invaluable friendly encouragement of all my scholarly endeavors. I tested the ideas of this paper at a meeting of the student discussion group at the CREES, and I am grateful to all who participated in it for their helpful comments.

My study has also benefited from a grant for attending the Summer Research Laboratory at the University of Illinois at Urbana-Champaign (in June, 1997) where I presented my paper at a joint meeting of two groups - Eighteenth-Century Russian Studies and Women in Slavic Cultures and Literature. Valuable suggestions and comments by David M. Goldfrank, Robin Bisha, Lisa Crone, and many others significantly contributed to the enhancement of this work.

My debt of gratitude goes to Evgenii V. Anisimov (The Institute of Russian History, Russian Academy of Sciences, St. Petersburg) and Donald J. Raleigh (The University of North Carolina at Chapel Hill) for their personal support of my academic career, first in Russia and then in North America. Our long conversations full of invigorating insights have always challenged me to expand and deepen my research. I wish to thank Robert Barclay, Galina Rylkova, and Jennifer Clibbon for their tireless reading of my manuscripts, their constructive criticisms of my ideas, and their friendship I so much appreciate. My heartfelt thanks to Wilson Robert Augustine (Glendon College, Toronto) whose knowledge of the subject and patient reading of this essay have been extremely instrumental in making it better. The impartial analyses by the three anonymous readers for The Carl Beck Papers have been highly beneficial for the 
quality of this paper and I am grateful to them.

My husband Vladimir Oslon has always been the first reader and the most critical editor of all my books and articles. His continued intellectual and domestic support have made my academic career smooth and my personal life happy. To him and to our son Michael I dedicate this study. 


\section{Introduction}

Liza advanced into the depth of the wood. The deep murmur of the waving branches seemed to welcome the young girl. Her gaiety vanished. . . She thought-but who can say exactly what a young lady of seventeen thinks of, alone in a wood, at six o'clock of a spring morning?

-A. S. Pushkin, "An Amateur Peasant Girl”."

The poet did not undertake to find out what the young girl's thoughts and dreams were, so I will try to reconstruct them. Fantastic as they sometimes are, dreams nevertheless reflect the ideals predominant in society and express people's attitudes toward personal happiness and social well-being. The realities of life inevitably underlie them. Individual circumstances, as well as many social, economic, and cultural factors, have a bearing upon the relationship between a person's dreams and reality. Closely interwoven, they make up a sort of microcosm that may be balanced or conflicted. Focusing primarily on the intellectual side of this microcosm, I will consider the aspirations of Russian provintsial'nye baryshni (provincial young ladies) and their everyday life over the 150-year period after Peter the Great's reforms.

In Pushkin's day as well as in preceding times, a girl's early years remained a series of stages preparing her for marriage, deemed the main event in her life. Until the age of twelve or thirteen in the eighteenth century, and the age of fifteen or sixteen about a hundred years later, she lived in the relative privacy of her family, nurturing a pattern of her forthcoming adulthood. The idea of marriage permeated the very essence of her daily life, entirely encompassing her aspirations, education, pastimes, and participation in social life. When the time came for her hopes to materialize, reality rarely fit the dream. They were like the poetry and prose Karolina Pavlova used in her tale Dvoinaia zhizn' (A Double Life, 1848) to depict, respectively, the heroine's lofty reveries and the boring banality of her real life. ${ }^{2}$

This essay examines the far-reaching effects of cultural progress on the soul and personality of a young noble girl in the provinces. I show how changing social ideals and norms of conduct affected both the expectations of provintsial'nye baryshni and the realizations of those expectations in their married lives. Among my main themes are the image of an ideal husband in the dreams of young girls; the corresponding image of an ideal wife in the eyes of society (men's eyes in particular); the importance of education and intellectual activities in girls' and young ladies' lives; and the new, westernized values and trends that gradually came to prevail over the traditional lifestyles prescribed by the Domostroi (household order) code.

I consider the evolution of reading habits and tastes to be an essential factor in 
intellectual growth in the provinces and among young ladies in particular, and I therefore touch upon this issue throughout the whole study. I also pay some attention to sexual relations as an important aspect of marriage and as a clue to determining the limits of "the right" and "the wrong" in the context of the time; however, in accordance with the principle formulated by Michel Foucault and followed by the editors of Sexuality and the Body in Russian Culture, I bring in sexual matters only insofar as I consider them to be "symptomatic of and constructed by a culture." I adhere to a similar principle when occasionally touching upon issues such as the organization of byt (everyday routine), household economy, women's legal status, and so forth. All these aspects allow me to trace the sociocultural transition from tradition to modernity in the provinces and to illustrate the liberalization of overall views about women's roles in family and society.

During the century and a half following Peter the Great's reforms, Russia changed from a patriarchal society with a medieval economy and culture into a powerful empire with a relatively developed economy and an enlightened culture. Admiring the West, Peter the Great had, among his other intentions, that of pulling the Russian noblewoman out of the terem (women's quarters) and turning her into the jewel of society. In many European countries, France in particular, women participated extensively in public life, creating their own places of authority through the Enlightenment salons. ${ }^{4}$ However, a contemporary's assessment of France in the 1770s and 1780s_-"women reigned then"- - was by no means applicable to Russia of the same period. ${ }^{5}$ Despite the fact that women actually sat on the throne in Russia throughout the last threequarters of the eighteenth century, the country remained a man's realm.

Yet the crucial changes brought about by the reforms would eventually extend to all facets of life, including women's standing in society. One characteristic of Russian reality in the eighteenth century was, indeed, the increasing disparity in the ways of life between noblewomen and women from other social groups, especially the peasantry. This disparity most conspicuously manifested itself in women's everyday involvement in the social and cultural spheres. While these spheres continued to play no more than an episodic part in the existence of non-noble women, their priority in the nobility's system of values was constantly increasing. ${ }^{6}$ The type of a self-conscious, well-educated, and socially active noblewoman emerged by the beginning of the nineteenth century. Depicting this process, Iurii Lotman has, however, emphasized the relative exclusiveness of this type:

One should not, of course, assume that such women were very numerous. "Dikie poineshchitsy [uncivilized female landowners]" existed as well, and even in greater numbers. There also existed those sweet, meek women, not at all bad, whose only ambition was expressed in pickling cucumbers and laying in food for winter-starosvetskie pomeshchitsy [old-fashioned female 
landowners], so agreeable, so good. But the fact that there were now people of ideas in society - women to no small extent — created a totally different daily life. $^{7}$

Setting aside the extremes - the lionesses of the beau monde and the dikie pomeshchitsy - I focus on those "sweet, meek" ladies who lived in the Russian provinces. By presenting the lives of several real and fictional characters I demonstrate how provincial young ladies worked their way up from the submissiveness inculcated by the Domostroi code to a quest for personal happiness and more conscious choices.

It is probably fair to say that the conflict between girls' dreams and reality was not too sharp in Petrine times, when girls hardly even dared to think of a life different from that of obedience and humility which their mothers and grandmothers had lived according to age-old patriarchal traditions. Even after Peter's reforms, they long remained silent and passive, seldom assuming roles of any real independence or importance. They acted mostly in the private sphere of the family, for public life scarcely existed in the provinces before the 1762 edict "On the Emancipation of the Nobility."

After the 1760 s, the public eye slowly started to turn toward personality and individual values. Although "pickling cucumbers" continued to take up much of young ladies' time and effort, ideas and intellectual interests gradually pervaded the starosvetskii byt (old-fashioned daily routine), altering the expectations of provintsial'nye baryshni but leaving reality largely intact. This discordance sharpened the conflict between dream and reality. However, education for baryshni was gradually gaining general recognition; their contribution to the atmosphere of public gatherings was increasing; and they even started, early in the nineteenth century, to enter the field long considered to be a man's prerogative-literature and art. I will show how these and other developments both resulted from the growth of public life in the provinces, and facilitated its further progress.

By the mid-nineteenth century many women, both in the capitals and in the provinces, had acquired unprecedented independence in organizing their lives according to their own tastes and needs, so the discord between their dreams and reality grew less acute. By that time one can discern a new feminine type, which I would characterize with the word lichnost' (personality), implying certain personal qualities such as education, intelligence, self-confidence, and awareness of one's own needs. Close in its social meaning to the male type of a developed personality, the feminine lichnost' differed from it, however, by preserving stronger ties with the private sphere, as the emancipated women of the time remained family-centered rather than socially oriented. In turn, the private sphere began to play a new part in the lives of such women: once an institution of oppression, it was becoming the sphere of intimate freedom and self-expression.

Having, for obvious reasons, emerged in the capitals, the new type of woman 
assumed a slightly different incarnation among young provincial ladies. Resulting from both the deeper preservation of traditional values and the more limited access to material sources of culture in the provinces, this difference was manifest in the stereotype of provintsial'nye baryshni, which connoted a certain degree of inferiority or backwardness. This stereotype, while not groundless, failed to convey the real meaning of the underlying phenomenon.

Russian fictional literature of the last century described quite extensively the character of the provintsial'naia baryshnia, but historians have done little serious research on the subject. The overall evolution of social ideals and the shaping of stable norms of behavior in the eighteenth and first half of the nineteenth century have been thoroughly researched, as have the changes in the family and in women's lives. ${ }^{8}$ However, the majority of works on women's history refer to the period from 1800 onward. The first generalized survey of Russian women's history, by Natalia Pushkareva, offers a chapter on the women of the Enlightenment, but it centers primarily upon the royal family and the aristocracy. Iurii Lotman's monograph, dedicated to the period from Peter the Great's reforms to the beginning of the nineteenth century, treats "the world of woman" in several chapters but pays little attention to provincial life. ${ }^{9}$

Researchers studying life on the country estate have emphasized its particular and unique significance to Russian culture. ${ }^{10}$ They too, however, have mostly devoted their attention to the rich and powerful whose country life was primarily a complement to, or a distraction from, their life in the capitals. Taking as a starting point the fact that the majority of the noble population could not afford to live in the capitals, I focus on women from modest noble families who lived in the provinces and never, or only for short periods of time, came to Moscow and St. Petersburg. " I show that their lifestyles differed from those in the capitals by preserving intact certain pre-Petrine social practices and moral norms as late as the nineteenth century, while still generally following the main trends of cultural progress in the capitals.

In order to discover what formed young ladies' dreams and determined their reality, I present chronologically, through their own voices where possible, provintsial'nye baryshni of several succeeding generations. The choice of heroines for this essay is rather arbitrary: I make no attempt to examine the Russian nobility in its entirety, or to present tipichnye predstaviteli (typical representatives) of a social stratum, as used to be common in historical studies of the past, especially in the Soviet Union. On the contrary, I am fascinated by some individual lives - ordinary to the extent a human life can be ordinary — or rather extraordinary in the context of their time. In any case, I try to analyze how the realities and aspirations of particular women, real or fictional, were related to those of the majority of their contemporaries. The evidence comes from published and unpublished letters, diaries, memoirs, family chronicles, and fiction. 
There exist only limited sources on Russian women's own opinions about their lives and aspirations in the eighteenth century. Almost inaudible at that time, women's voices sound much more strongly in the first half of the next century, but nevertheless account for only a small part of the choir. Women's epistolary materials dating back to the eighteenth century are very sparse, as men at that time were little prone to preserve letters from their wives and daughters. In the beginning of the nineteenth century the number of women's letters, both to have been written and to have survived, increased dramatically, so we can place more confidence in this source. Diaries and albums, which first came into fashion in the 1770s and 1780s and were kept by several generations of young noblewomen, also shed light on their thoughts and interests. ${ }^{12}$ Another type of source revealing women's aspirations is folk divinatory practices, inherited from ancient times and popular among provintsial'nye baryshni during this entire period.

Russian women took their first steps in literary enterprise during the reign of Catherine the Great (1762-1796), following the example of the empress herself. ${ }^{13} \mathrm{In}$ 1857 Nikolai Kniazhnin published the first list of Russian women writers, as a tribute to the centenary of their writing. The publisher prefaced the publication with the following remark: "Unfortunately, our women writers are almost unknown to the reading public, even by their names, except for several of the most famous." ${ }^{4}$ The list contained an impressive number of about four hundred names, but even at that time Kniazhnin complained that the majority of their works had disappeared. Much more true is it today.

Memoirs and family chronicles written by women and bearing on this period are not numerous and have one characteristic in common: they are usually connected to the life of a prominent man. The works concentrate on the author's husband, father, or brother and provide relatively little information about the author herself. ${ }^{15}$ Materials written by men exceed those produced by women both in numbers and diversity, so one cannot bypass them even in a study dedicated to women. But my main reason for bringing such sources into the discussion is my intent to observe the issues from both woman's and man's viewpoints. Women lived in a male-dominated society, played roles conceived primarily by men, and largely depended on men's attitudes in the public as well as the private sphere. The outlook on women and women's issues, expressed in men's memoirs, documents, and fiction, thus provides additional dimensions to our perception of woman's standing in society and family at the time. Whenever possible, I juxtapose female characters' versions of particular situations with similar versions by men.

For the first half of the eighteenth century, I consider women's letters and folk divinatory practices, which allows me to argue that women's inferiority to men was assumed to be the norm both socially and culturally. To further corroborate this argu- 
ment, I track the life of a real woman of the time using the memoirs by Ivan Nepliuev (1693-1773), a statesman who started his career under Peter the Great and lived well into Catherine the Great's reign. Nepliuev rarely and only in passing mentions his wife in his rather detailed narration, so I draw on what little information on his family life he incidentally provides. This material demonstrates that, in the case of a poor provincial noblewoman, even the rise of her husband to the highest bureaucracy in Petrine and post-Petrine times might have little effect on her traditional way of life.

To depict the status of provincial women in the second half of the eighteenth century, I employ the well-known memoirs of Andrei Bolotov (1738-1833) and Anna Labzina (1758-1828). Ranking among the most valuable sources for life in the provinces in this period, these works express two divergent views on the subject of my study, their disparity ensuing not only from gender but also from the authors' different overall attitudes toward the cultural changes taking place. Aiming to present his own life as an edifying example for his offspring, Bolotov-a scientist, a writer, and one of the most educated men of his time - positions himself in the foreground of progress and puts forward conceptions as advanced as he can possibly conceive. In contrast, Labzina--a provincial noblewoman of traditional upbringing - describes her life as a nightmare originating with her enlightened husband, who had abused her innocence and her adherence to age-old beliefs.

The history of four generations of the Bunin-Kireevskii-Yelagin family is filled with young girls' voices. They wrote numerous letters to each other; their albums contain their own thoughts and quotations from their favorite authors; they translated novels and poetry; and even left some memoirs. Because the famous poet Vassily Zhukovsky (1783-1852) belonged to the Bunin family, a wealth of documents written by his sisters, cousins, and nieces has been preserved and was published in part after his death. Rich in details of the provintsial'nye baryshni's lives, this material spans a period from the 1790s through the 1840s. Its significance for my study is twofold: on the one hand, this typical provincial noble family personifies the phenomena I intend to discuss; on the other hand, the peculiar atmosphere in this family, which produced an amazing number of prominent figures, both men and women, allows me to trace the increasing part that intellectual activities played in women's everyday life in the first half of the nineteenth century. This material also provides grounds for certain generalizations about society's turning, by the end of the period of my study, to more respect for woman's personality and needs.

I chose the novels by Dmitrii Begichev (1786-1855) as a counterbalance to the Bunin-Kireevskii-Yelagin material. I consider it useful to compare those girls' own views with the judgment articulated by a conservative male moralist, who claimed to represent more than just himself. Begichev described a less refined stratum of provincial society in the $1810 \mathrm{~s}-1830$ s than that inhabited by the Bunin girls. Yet his fictional 
baryshni's expectations, interests, and values are close to those of their real counterparts, and their milieu is similar to those described in nonfictional sources. Begichev's novels depict a peculiar mixture of patriarchal tradition, still alive and affecting young women's lives, and westernized norms, increasingly accepted and observed by provincial society.

I also consider valuable the data to be found in Begichev's texts about his fictional heroines' reading habits, which very much resemble those revealed by the letters and diaries of real women. Virtually all the authors who ever wrote about provintsial'nye baryshni placed particular emphasis on the significance of reading in their lives. I will demonstrate that at the end of the eighteenth century books became a source of constant and profound influence on young ladies' souls, minds, and behavioral ideals. Looking back to this period, the poet Apollon Grigor'ev remarked in 1859: "Books for us are not simply books, the matter for study and entertainment: books used to turn and still turn directly into our life, our flesh and blood, they often changed and still change the very essence of our moral universe..." ${ }^{16}$ More than any other group, provintsial'nye baryshni embodied this observation. In my analysis I show that literature largely determined their dreams and often contributed to their reality.

\section{"... how charming these provincial young ladies are!"}

Being somewhat archaic, the Russian concept of baryshnia has lost in modern usage its unambiguous social meaning, even when applied to the pre-Revolutionary period. The Dictionary of Modern Russian (Moscow, 1991) provides four definitions: (1) a gentleman's unmarried daughter; (2) fig., colloq.: person who shirks rough or dirty work; (3) becoming archaic: girl, maiden; (4) archaic: female telephonist. In the eighteenth and nineteenth centuries the term definitely implied a noble origin. Dal' defines baryshnia as "a girl of noble status."'77 The meaning altered in the beginning of the twentieth century owing to the democratization of daily life and the rapid emancipation of women. With unconcealed irony, the philosopher Georgii Fedotov described this process:

In the evenings, crowds of young people in jackets and Russian shirts stroll along city boulevards with baryshni, who are dressed according to current fashion but have apparently never been to gymnasia. They eat sunflower seeds, exchange compliments. . . . They strive to mind their manners but are awfully out of tune. Maids wearing bonnets and talking cheekily scandalize officials' wives, their mistresses. Undoubtedly, the maid-half-serf yesterdayis turning into a baryshnia. She already demands that she should be thus addressed. ${ }^{18}$ 
In this essay, I use the word baryshnia in its historical meaning, that is, a young, unmarried girl from a noble family.

In literature and everyday life, a rather persistent stereotype reflects society's attitude toward provintsial'nye baryshni, the word provintsial'nye (provincial ones) being of particular significance. Provinces were not only the administrative units of the Russian state, but localities situated far from the center of the country. The word has a condescending aspect, because public consciousness, formed in the capitals, associated provincial customs, lifestyles, and tastes with backwardness, ignorance, and boredom. ${ }^{19}$ Thus, the stereotype acquired a sociopsychological rather than geographical meaning. Here is another classic excerpt from Pushkin's "Baryshnia-krest'ianka"("An Amateur Peasant Girl"):

Those of my readers who have never lived in the country, cannot imagine how charming these provincial young ladies are! Brought up in the pure air, under the shadow of the apple trees of their gardens, they derive their knowledge of the world and of life chiefly from books. Solitude, freedom, and reading develop very early within them sentiments and passions unknown to our town-bred beauties. For the young ladies of the country the sound of the post-bell is an event; a journey to the nearest town marks an epoch in their lives, and the visit of a guest leaves behind a long, and sometimes an eternal recollection. Of course everybody is at liberty to laugh at some of their peculiarities, but the jokes of a superficial observer cannot nullify their essential merits, the chief of which is that personality of character, that individualité, without which. ... there can be no human greatness. In the capitals, women receive perhaps a better instruction, but intercourse with the world soon levels the character and makes their souls as uniform as their headdresses. ${ }^{20}$

Other examples show that qualities such as naïveté, peevishness, bashfulness, lack of refinement, were commonly attributed to young women from the provinces. ${ }^{21}$ A more careful analysis of some of their portraits, however, reveals such fascinating integrity and charming beauty that the images of most of the brilliant ladies of fashion pale by comparison. So, where did this stereotype come from and to what extent is it true?

The relationship between the capital and the provinces in a country's history, in the shaping of the character and identity of its population, is a broad issue requiring thorough and serious discussion. Historical events that occurred in the capitals and determined the trends of economic, political, and cultural growth, have rightly attracted most of the attention. However, as Michael Kugler argued with respect to European history, "the nature of provincialism has not been outlined in detail"; this certainly applies to the history of Russia. ${ }^{22}$

The strict hierarchy of societal structures in Russia assumed that both material 
and spiritual values emanated from the center. Accordingly, everything deemed "good" and "right" ought to be found in the capitals, even if it originated elsewhere. The idea of krasnyi ugol (red corner), intrinsic to the Russian consciousness, dominated all spheres of life. ${ }^{23}$ In a Russian house the red (the beautiful, the best) comer was a sacred place where the icons hung and where the most venerable guests were seated. In a peasant's $i z b a$ (hut) and a nobleman's mansion equally, this place was subject to extensive care and served as a measure of the master's social standing. Every town proudly maintained its own krasnyi ugol, often the only paved place or street and typically identified by the church and the local government building. ${ }^{24}$ And all the best in Russia converged on the country's krasnyi ugol-its capital-where ideas, fashions, norms, and rules originated along with the government's decrees.

Jean-Jacques Rousseau was one of the first to note the importance of observing life in the provinces. In Emile he wrote: "To study the genius and the character of a nation you should go to the more remote provinces, where there is less stir, less commerce, where strangers seldom travel, where the inhabitants stay in one place, where there are fewer changes of wealth and position.... The French are not in Paris, but in Touraine; the English are more English in Mercia than in London, and the Spaniards more Spanish in Galicia than in Madrid." ${ }^{25}$ We might venture to say that Russians are more Russian in Tula and Riazan' than in St. Petersburg and Moscow. In such a vast country, the lifestyle of the capitals was an exception rather than a rule. More patriarchal and less susceptible to swift change, public and private life in the provinces presented some contrast to the capitals. Traditions and restrictive norms, deeply entrenched and strictly maintained in provincial society, formed the basis for a pronounced tendency to accept selectively, and at a considerably lower speed, only the most viable innovations. This sociocultural conservatism helped, in a certain way, to cushion the sometimes harsh consequences of the reforms. ${ }^{26}$

Peter the Great's military and administrative innovations made heavier and more regular the burden of obligatory state service imposed on the Russian nobility. The longer, if not permanent, absence of the male noble population from their homes; little inflow of novel ideas to stir up the patriarchal traditions; poor funding of education outside the capitals - all these factors contributed to the obvious cultural lag of the provinces. Education for young noblemen, much in demand after the Petrine reforms, was available at the newly established professional and elementary schools in Moscow and St. Petersburg. Peter's attempt to organize a broader educational system of elementary "cypher" schools in provincial towns had little success and failed right after his death in 1725. The small number of church-run, state-owned, and private schools in the provinces by no means met the demand. A national network of schools was established in Russia only in 1786, when about four hundred schools of various levels opened in the provinces following Catherine the Great's Statute of National Schools. ${ }^{27}$ 
Even then, the majority of noble families still preferred to send children to better and more prestigious schools in the capital cities.

With the emergence of the first Russian newspaper Vedomosti (1702), as well as several publishing houses in St. Petersburg, periodicals and books began to reach the provinces, but the numbers were far from significant during most of the eighteenth century. Only much later would the situation in the provinces become comparable to that in the capitals through a series of developments such as the establishment of the networks of local publishing houses (in accordance with the 1783 edict but in reality by the 1820 s and 1830 s), public libraries (in accordance with the 1830 edict), local periodicals such as Gubernskie vedomosti (in accordance with the $1838 \mathrm{edict}$ ), and bookstores. ${ }^{28}$

In the second half of the eighteenth century a new trend becomes discernible in the public life of the Russian nobility: literary salons patterned after the contemporary French model. ${ }^{29}$ The salon created a unique culture that combined the public character of noble gatherings with the privacy of a home. When socializing in such an atmosphere, one was less subjected to normative restrictions and official etiquette. This circumstance gave a new and public meaning to the role of the lady of the house. As hostess, a woman would often become the life and soul of these gatherings, where powerful and well-educated men would seek her attention and pay heed to her opinions. Here, the Fénelon rule, which prescribed that a woman keep silence unless addressed, was completely abandoned. For the first time in Russian history (if we exclude the empresses and their female favorites), women had opportunities, if only potential, to gain some public recognition as individuals. Personal qualities such as education, talent, character, manners, and, certainly, good looks, began to play a part of importance in shaping a woman's independent social status.

While cultural life in St. Petersburg and Moscow revolved around some two hundred literary salons by the mid-nineteenth century, only about thirty are known to have existed in the provinces. ${ }^{30}$ For provincial noblemen, especially those who lived on country estates, economic and agricultural issues had a higher priority than intellectual pursuits. Discussions at provincial noble assemblies focused primarily on prices and harvest, hunting and fishing. ${ }^{31}$ Women would rarely become the centers of those discussions. Nevertheless, the phenomenon of salons, here and there growing out of regular public gatherings, indicated the increasing intellectual level and cultural progress of provincial society. Several women from the Bunin family were among the wellknown hostesses of literary salons.

Thus, the obvious gap between the capitals and the provinces notwithstanding, the stereotyped opinion about the total ignorance of the eighteenth-century provincial nobility is no closer to the truth than the myth that in the second half of the century "with respect ... to both intellectual and moral development, no significant differences 
could be found between the provincial milieu and that of the capitals." ${ }^{32}$ Indeed, the gap existed and never completely closed, but the provinces were constantly on the move to catch up with the capitals. Most importantly for our study, noblewomen were the first both to suffer from the cultural lag and to benefit from cultural progress, as they constituted the majority of the permanent noble population little exposed to life beyond country estates.

\section{The End of the Seclusion of the Terem}

One of the effects of Peter the Great's reforms, the ending of Russian women's seclusion in the terem, could be considered as their emerging from an exclusively private, domestic sphere into public life. In reality, however, the boundary of those two spheres was rather fuzzy; as Lawrence Klein puts it, "the distinction between the private and the public did not correspond to the distinction between home and nothome" and "the private sphere referred to all that was not related to or sponsored by the State." ${ }^{33}$ Both public life and the economic sphere preserved some private facets and, vice versa, the private sphere included many not-so-private aspects. Philippe Ariès, the editor of A History of Private Life, has suggested that the degree of privacy in eighteenth-century Europe could be judged by people's taste for solitude, leading to new ways of organizing daily life. ${ }^{34}$ This indivisibility of the public and the private, as well as the emergence of a new conception of daily life, also characterized eighteenth-century Russia. ${ }^{35}$

Traditional roles in a noble family were generally polarized along gender lines: men, as state servants, primarily functioned socially and publicly, while women were supposed to act in the private sphere of their homes. There exists, however, historical evidence that even in pre-Petrine times some women not only ran households but also participated in legal proceedings, conducted business, and sold goods and property, especially in the absence of their husbands. ${ }^{36}$ Although such occurrences were not common, and a woman's out-of-home activities rarely extended beyond the passive execution of her husband's orders, they certainly prove that transcending the terem's confines was not unheard-of.

The daily life of a noblewoman, whether married or unmarried, was not altogether private either, even if nothing disturbed the ordinary routine of her domestic universe. Constantly surrounded by serfs and relatives, she could spend hardly any time alone. The houses inhabited by noble families of average means usually had no separate, private rooms for women, so several women would share one. Sometimes, there were no separate women's quarters at all. ${ }^{37}$ Conjugal relations and family matters were largely exposed to public observation: relatives and neighbors, when asked for testimony in case of a family conflict, invariably proved to be well informed. ${ }^{38}$ Thus, 
although their existence revolved primarily around private matters, women neither enjoyed nor craved privacy in the modern meaning of the word. The taste for solitude, as a yardstick for the then emerging concept of privacy, did not really develop in the minds of Russian provincial noblewomen until the very end of the eighteenth century, when intellectual activities, such as reading, drawing, thinking, and dreaming became common to many provintsial'nye baryshni. Notably enough, these trends contributed to many innovations in household arrangements, including the architecture of country homes. ${ }^{39}$

In the eighteenth-century Russian provinces, long after Peter the Great's reforms, religious traditions and old customs had often more effect on everyday life than the new laws. The pre-Petrine Domostroi-inspired legal norms and regulations continued to shape society's attitudes toward young girls. Although Peter had repealed the 1649 law that a parent guilty of infanticide should be punished by no more than one year in jail, parents generally considered their children still subject to their total and unquestioned authority. ${ }^{40}$ In 1735 , for example, the Governing Senate brought murder charges against the nobleman Nikita Demidov, a rich and powerful factory owner in Tula, who had been under investigation since 1733 for allegedly concealing profits and evading payments to the treasury. When his daughter Tat' iana suddenly died in 1734 of unknown causes, rumors spread around town that the father had killed the girl because her excessive curiosity had led her to discover one of his secret caches. Due, presumably, to some bribes offered and accepted, the murder case was hushed up, but the charges of fraud were strenuously pursued and brought to light numerous violations of the law committed by Demidov. ${ }^{41}$ The authorities must have deemed economic crime more serious than the murder of a daughter.

The influence of the Domostro $i$ was especially manifest in matters related to a daughter's marriage. A decree of Peter the Great declared the consent of both the bride and the groom mandatory in order for them to marry, but in reality the new law was only formally observed. Children's obedience in these matters was considered not only a virtue, but also a duty toward their parents. Society, for its part, subjected a young lady to judgment by the age-old template: the ideal bride brought with her a good dowry and the ability to be an obedient wife, an assiduous housekeeper, and a good mother. ${ }^{42}$

In the first half of the eighteenth century a girl was unlikely to look forward to her marriage with hopes for love, independence, and fulfillment, as would become common a century later. ${ }^{43}$ Love as spiritual and sexual intimacy was rarely relevant, the main factor was marriage per se. Folk divinatory practices, equally popular among both krest'ianki (peasant women) and provintsial'nye baryshni, reveal this attitude in girls' dreams. ${ }^{44}$ Fortune-telling about a future husband almost never referred to a would-be bridegroom's specific qualities. The dividing line was usually drawn in a 
very general way: young or old, mólodets (bachelor) or vdovets (widower), rich or poor. The refrain primarily contained a request to be awarded a husband, bo ia zamuzh $k h o c h u$ (for I want to get married), and only rarely was the fortune-telling performed in order to learn about a girl's chances of happiness, largely understood as prosperity. Some of the personal features desired in a husband can be found in fortune-telling practices of noble girls only in the beginning of the nineteenth century, when divinatory texts came to express the almost universal demand for brave army officers. ${ }^{45}$

The ritual of parting with girlhood on the eve of the wedding included valedictions to krásota (freedom), which was going to be handed over to the bridegroom, and an allegorical dismemberment of the bride herself in order to get rid of gady (vile creatures) that represented girlish attraction toward shalost' (frolicking). Healed, the bride was supposed to surrender entirely to her husband's will. ${ }^{46}$ It is noteworthy that the incertitudes of a marriage to an almost unknown man aroused less fear than the bleak prospect of remaining unmarried. After the conventional age for marrying, about twenty at that time, an unmarried noble girl would almost certainly forfeit the selfconfidence and comfort she used to enjoy, and end up in the social and emotional liminality of spinsterhood. ${ }^{47}$

The realities of married life would often turn out to be sad and bitter. In the early eighteenth century, the husband remained the sole arbiter of a married woman's destiny, as in previous centuries..$^{48}$ Numerous legal cases of the time reveal the unquestioned authority that husbands wielded over their wives. A dissatisfied husband would put his unwanted spouse in a cloister for the rest of her life or, without taking the trouble to observe any legal proprieties, simply separate from her and embark on a new matrimonial union. In the first half of the eighteenth century informal separations became a widespread practice in the provinces, where neither ecclesiastical nor civil authorities were efficient enough to regulate marriage.$^{49}$ Even in a happy marriage, women often felt insecure and deprived of support while their husbands were performing military or civil service far from home. Uncertain about the future and vulnerable to adverse circumstances, many provincial noblewomen would fall victim to violent attacks and oppression. Such tragedies, common in pre-Petrine times, occurred in the eighteenth century as well.

An episode of this kind echoed in the Bolotov family long after it happened in 1659. Eremei Bolotov and his sons were fighting against the Poles, while his wife and an unmarried daughter stayed at home. One cold winter night, brigands attacked the estate, plundered the house, and tortured the mother to death; the daughter, bare-foot and almost naked, fled to a neighboring village where she later died of cold and grief. ${ }^{50}$ In 1769 two distant relatives of Andrei Bolotov's, a widowed mother and her young daughter, were tortured and killed by their peasants. ${ }^{51}$ As late as the 1780 s, another family related to Bolotov was in trouble: the future historian Nikolai Artsybashev's 
mother was turned out of house and home by the relatives of her father-in-law's second wife. As Artsybashev was only eight years old when his father died in 1781 and his mother had no legal right to the estate, the property was placed in the custody of the relatives who assumed and successfully performed the roles of brigands. He later described what the trustees had done to his estate as "not worse than what the French did to Prussia: everything was pillaged." Deprived of everything, Artsybashev's mother had the only recourse a woman could think of at that time-remarriage. ${ }^{52}$

These events, which took place within one family, were by no means exceptional. In more than a century the situation in the provinces had changed little: a woman without a husband remained totally unprotected against those willing to profit at her expense. The following letter, written by a wife to her husband at the turn of the eighteenth century, presents quite realistically the circumstances of a noblewoman left alone on the country estate:

To my sovereign Aleksei Iakovlevich thy unworthy wife Fekla bows low; with thy children Petr and Mikhail, hardly alive in my sorrows, I subsist in my small house in the village of Korenkovo; our serf Mishka ran away from the village of Korenkovo; as to the money thou hast, my sovereign Aleksei Iakovlevich, deigned to mention that thou my sovereign wilt need money, so if it pleases thee I want to sell or pawn my fur coat, or as it pleases thee my sovereign; ... . and the animals [livestock], those that are still out there are starving; .... and neither the men [male serfs] nor the maids [female serfs] obey me, the only man who remains is Vaska; so I sent the man Vaska to thee my sovereign, and having said all this thy unworthy wife Fekla bows low to thee. This letter to be handed to Aleksei Iakovlevich Spev at the post in the town of Tver'. ${ }^{53}$

This missive illustrates not only the loneliness but also the poverty that often fell to the lot of the wives of serving noblemen. The majority of them were poor to such a degree as to be short even of serf labor. Russian literature contains numerous examples of young noble ladies performing hard manual work: kniazhna (prince's daughter) Feklusha, in a novel by V. Narezhnyi, is used to weeding cabbage and carrying water with a yoke, while N. Leskov's Princess Protazanova “tended turkeys" before marriage. ${ }^{54}$

Another characteristic of the above letter is its language and style. The text is full of humble and submissive figures of speech which, no matter how private the subject, reveal the positions in the hierarchy occupied by both the writer and the recipient. Other women's letters of pre-Petrine and Petrine times prove that these figures of speech were very commonly used: thy unworthy wife (zhenishko tvoe) Avdotitsa; thy unworthy sister (sestrishka tvoia) Grunka; your unworthy daughter (docherishka vasha) Fedorka, and so on. ${ }^{55}$ One could argue that, having turned into clichés, some derogatory expressions tend to dilute the negative meaning they connote. True as this 
may be, one cannot help noticing that the ubiquitous use of self-humiliating diminutives was the first to be dropped in women's letters after the beginning of the reforms. While still teeming with expressions of humility and polite respect, women's letters are now signed, simply and with dignity, as "your wife" or "your daughter." Mar'ia Kireevskaia, the Bunin-Kireevskii-Yelagin girls' great-grandmother, wrote to her husband in 1716:

To my sovereign Ivan Ivanovich, be healthy my sovereign Ivan Ivanovich for many years, please my sovereign have a letter written to me about your perennial health, so I thank Christ and be grateful to God, and I hope thou dost kindly remember me, and thank God I am alive in my sorrows and Mariushka too.... Please deign to write to me soon and I remain thy wife Mar' ia from the village of Dolbino this February 13 of the year $1716 . .^{56}$

Mar' ia's daughter Nastas'ia wrote the same year using similar expressions:

To my sovereign and father Ivan Ivanovich, the right hand of the Most High preserve your health for many years, please deign my sovereign father to write to me about your perennial health and about the health of my sovereign mother Mar'ia Dmitrevna. ... Your daughter Nastas'ia has written this and I ask for your blessing and bow to you this July $11 .^{57}$

Self-humiliation gradually gave way to self-respect; in a century, both the form of address and self-identification would completely change. Thus, conventional deference has a touch of intimacy in a 1796 letter by Bolotov's daughter, Ekaterina, when she addresses her elder brother and sister with a combination of respectful diminutives and concludes with a rather playful "ruchki tseluiu" ("I kiss your hands"). ${ }^{58}$ In the 1800 s, the word "friend" formed the basis for a new set of largely accepted epistolary clichés in women's letters. For example, the Bunin-Kireevskii-Yelagin girls frequently use it in letters not only to each other but also to their elders (see below); in an 1812 letter, a wife addresses her husband as "my dear invaluable friend" and signs, "Fare thee well, Jesus be with thee, thy friend forever Annushka." 59

Peter the Great's reforms impacted not only socially but also emotionally on women's lives. The innovations went far beyond Peter's intention to, using his own expression, slightly "polish" people. ${ }^{60}$ In about a quarter of a century, a series of stateimposed measures subjected women's personal lives to meticulous attention by society and the state. Russians' understanding of what constituted decency and sin for women would change, leading to many collisions between age-old tradition and the new-fangled westernized ideas. For some women, these collisions resulted in mental disorder, the veil taken, or an extremely dissolute life. The 1717 book Iunosti chestnoe zertsalo (Honest Mirror of Youth) included a special section advising girls against immodest behavior. With deprecation, it referred to those excessively emancipated 
girls who "sing dissolute songs, make merry and get drunk, hop on the tables and benches, let themselves be pulled and dragged into all corners like harlots." ${ }^{\prime 61}$ Such conduct, encountered primarily in the new capital, was a result of the dramatic changes in the moral code.

Little as Peter paid attention to what is now called "public relations," his decrees' eventual success, at least in the private sphere, largely depended on whether people would accept them. It is well known that Peter's reforms met fierce resistance from those committed to ancient customs, and one should not underestimate the psychological stress, even when changes appealed to people. For instance, it took some time for Russian beauties to develop a taste for the assemblies and public balls, after the initial embarrassment at being required to participate; and the coercive introduction of alcohol and tobacco stirred up resentment among many. One of Peter's earliest measures to arouse controversy was the introduction of European-style clothes by a 1700 decree, which did not simply change the dress code but strongly impacted on several aspects of Russian life. ${ }^{62}$

Although the particular garments varied, a woman's traditional costume was designed to be buttoned or hooked up to the throat, for decency required that the bosom be completely covered. Ornaments and necklaces adorning the upper parts of the clothes were believed to ward off evil spirits. A married woman ought not to uncover her hair even in her family's presence, as it was a sin to let anybody see it (in the Novgorod region the custom went so far as to shave the hair off so the husband could not see it).$^{63}$ The language has up to today preserved the verb oprostovolosit'sia (literally, to uncover one's hair) meaning to behave shamefully, to make a fool of oneself. To many people, the women's clothes demanded by the 1700 decree appeared totally disreputable; European-style dress exposed women's breasts and shoulders, and the headdress did not cover the hair. ${ }^{64}$ In addition, many would feel concern about loss of protection against evil. Respectable matrons objected to exposing themselves and their daughters like fallen women. In 1705, after the decree was read aloud in the church in the town of Solikamsk in the Urals, old men, scandalized and horrified, began talking about the "End of the World."

In Moscow, as far back as the first half of the seventeenth century, there were Russian courtiers who wore French and German clothes, and by the end of the century a considerable number of foreigners were living in the city. Muscovites were thus used to seeing Western costume, but in the provinces foreign dress was completely unknown at that time. ${ }^{66}$ In 1696 , for instance, the dowry provided by one provincial nobleman for his daughter included clothes in traditional Russian style only. ${ }^{67} \mathrm{By}$ the mid-eighteenth century, however, the German cut of formal garments predominated in noble brides' dowries, while traditional Russian clothes were worn primarily at home. Thus, Praskov'ia Bolotova, a colonel's daughter betrothed to a nobleman from Pskov 
region, was given 300 rubles' worth of clothes on her wedding day in 1745 , the formal garments being of European style. Made out of the old-fashioned Russian fabrics, they presented a somewhat peculiar combination of colors: "the green shlafor [gown] over the crimson skirt; another shlafor, crimson, the skirt is blue; the yellow halfshlafor, the skirt being green." Five corsets supplemented these fashionable dresses. For household needs, however, kanifasnye (traditional sort of fabric) balakhony (loose overalls) were in stock..$^{68}$

Interestingly enough, Russian lubok (woodcuts in folk-art style) during all of the first half of the century depicted "a bad wife" in German clothes and "a good wife" in traditional Russian ones.$^{69}$ Even a late eighteenth-century lubok ridicules the mixture of Russian and European clothes in a noble girl's dowry. Its customary doggerel unflatteringly describing the bride as "comely and ruddy like an ape; ... walking in a German fashion while speaking Swedish."70 This example proves that aversion toward foreign clothing could still be found among the common people, the lubok's traditional audience, as late as nearly a century after Peter the Great's reforms. Among noblewomen, Russian clothes were sometimes considered more appropriate for the elderly and the widowed as late as the mid-nineteenth century. ${ }^{71}$

\section{Fedos'ia Nepliueva, née Tatishcheva}

The rest of this section presents the story of a woman who lived in the first decades of the eighteenth century. She left no testimony of her own, but a careful reading of her husband Ivan Nepliuev's memoirs sheds light on a life that embodies many features common to other women of her class and time. ${ }^{72}$

In spite of her high connections, Fedos'ia Fedorovna Tatishcheva (b. before 1698, d. 1740), niece to the Novgorod governor Tatishchev, was not rich. Her dowry consisted of no more than twenty serfs. She could hardly expect to considerably improve her means by marrying the eighteen-year-old Ivan Nepliuev, who had only eighty serfs and a small village in the Novgorod uezd (district). His mother, recently widowed and in a hurry to settle her son's affairs, had precipitated this marriage, which took place in 1711. Within two years, Fedos'ia gave birth to two children and had to part with her husband who was called up to the tsar's service.

Nepliuev had a rapid and distinguished career. He became one of Peter's first naval cadets, sailed around Europe on board one of the first Russian battleships, and ended up among the tsar's retinue. On his return, Fedos'ia joined him in St. Petersburg, where he was assigned a well-paying position. However, in less than half a year the tsar appointed Nepliuev ambassador to Turkey. The salary of 3,000 rubles annually was immense by contemporary standards, but the payments would begin only 
upon the new diplomat's arrival in Constantinople.

The husband's promotion to the upper levels of the ruling hierarchy produced no beneficial effect on his wife's circumstances. He intended to send his family back to the country, for they did not possess sufficient means to subsist in the capital. AdmiralGeneral F. M. Apraksin, the young appointee's patron, called him "a fool" and reproached him in the following words: "What art thou leaving thy wife and children with? There's nothing they can now do but beg around; why hast thou not asked the Sire to give them a salary from us according to thy rank while thou art absent?"Nepliuev admitted that he had "never dared and never even thought" about it, which reply met the reasonable remark, "That is precisely why thou art a fool!"(112-13). In this scene we observe Nepliuev's ostensible unselfishness, combined with the traditional assumption that a nobleman, servant of the tsar and homeland, must be ready to set out on service at the first call, whereas his wife must remain in the country and feed on whatever the property yielded. ${ }^{73}$

Nepliuev's patron insisted that Fedos'ia should address her concerns directly to him; he even promised to provide her with some money should she find herself in any predicament. The young woman, once again pregnant, was nevertheless compelled to move to the country. Her new-born daughter died, and she subsequently lost her seven-year-old son. Her other son was in Turkey with his father, so her only companion was her elder daughter. She only saw her husband again after six years, when the authorities allowed her to go to Constantinople for that particular purpose. This time the spouses did not part for five years-the longest period in their life together-and she bore him two more children. Their next and last period together was even shorter. In 1740, soon after Nepliuev's return to Russia, Fedos'ia died while accompanying him on a business trip to Kiev. During twenty nine years of married life, she only spent about half that time together with him. In this respect, however, she could almost consider herself lucky.

The emotional side of the marriage is never given much attention in Nepliuev's text. Without expressing any feelings, the narrator simply records his wife's demise among other facts and events. Much as this reticence fits with the laconic style and rather withdrawn tone of the whole memoir, one cannot help noticing that the author omitted no detail in his description of the abundance of bitter tears he had shed when parting with the tsar. As to his wife's feelings, he only once touches on the topic, in passing, in connection with the following episode: having contracted a contagious disease in Constantinople in 1732, he locked himself up in a room and allowed nobody to enter. His wife, as Nepliuev impassively puts it, "from behind the door, continually beseeched me with tears to let her come in to see me"(111).

It is interesting to compare Nepliuev's attitudes toward his first and second wives. $\mathrm{He}$ is a little more emotional about his second wife, whose life turned out to be even 
sadder than Fedosi'ia's. He married her less than a year after becoming a widower. Now a highly influential official, recently promoted to privy councilor, awarded several large villages in the Ukraine and not yet old (he was forty eight), he married this time out of love rather than convenience. His new wife Anna, General-Lieutenant I. I. Panin's daughter, had every reason to expect much from her marriage. But two months after the nuptials, he suddenly fell out of favor and lost all his property. This circumstance dealt Anna a blow from which she never recovered. In his narration of these events, Nepliuev for the first time reveals his feelings: "Relying on God's will, I immediately left Glukhov and hastily continued my trip, in order to learn as soon as possible about my lot and console my suffering wife, who, having so little lived with me, found herself embroiled through me, though not by my fault as God knows, in such a calamitous and unknown state" $(131) .^{74}$

He managed to prove his innocence but rescued no property. His new assignment led him to the Orenburg steppes and Anna accompanied him on his journey. Used to the comfort of a rich Moscow house, she was unable to cope with the hardships of life in military camps, far from civilization. Soon, according to Nepliuev, "sadness overcame my wife who passed away in the same year [1743], in the fortress of Orsk"(140-41). The way he refers to the "sadness" that killed the young woman suggests a deep sentiment that he had never shown his first wife.

These two women lived and struggled long after Peter the Great's far-reaching reforms had been carried out, but before the real consequences of the innovations could penetrate very deeply into women's daily lives. In their capacity as wives to a man constantly poised to implement the monarch's will, Fedosi'ia and Anna remained totally dependent upon their husband's attitudes as well as his overall circumstances. On the other hand, there were in their lives manifestations of the new order: both were allowed, if temporarily and even to their own detriment, to join their husband while he was performing his duties. Although this development-the lifting of the seclusion of the terem - was in effect by the 1740 s, it did not drastically change the situation of women in the provinces. Patriarchal customs remained largely in place until late in the century, only reluctantly yielding to the new style of life.

\section{The Character "I would like my future life companion to have"}

\section{Aleksandra Bolotova, née Kaverina, and her daughters}

The 1762 edict "On the Emancipation of the Nobility" and the subsequent administrative reforms of Catherine the Great were designed to shape public life in the 
provinces. The establishment of corporate bodies for local self-government by the nobility boosted public activities and fostered the growth of society. The male population of the provinces was increasing due to the inflow of noblemen who chose to seize the opportunity to resign from state service and settle down to family life in their hereditary nests. Many of them came back from abroad after the Seven Years' War, so their luggage not uncommonly contained articles never before seen in the provinces; but more important, they had been exposed to European concepts of household practices and, some of them, to Enlightenment ideas. As these were significantly different from traditional Russian norms, the process of fusion of patriarchal customs and westernized values gained new momentum.

These trends are clearly shown in the memoirs of Andrei Bolotov. ${ }^{75}$ A nobleman of modest means, he retired from military service in 1762, returned to his estate in Tula Province and started looking for a wife. From people he met and from books he read while serving in Prussia, he had acquired some new ideas about matrimony. His concept of an ideal wife included not only material qualifications, but also aesthetic, ethi$\mathrm{cal}$, and even educational qualities. Without waiving the traditional requirement that the girl be of good character, Bolotov craved one who could share his intellectual interests. Following the fashion, his quest had first started in Moscow, where he became acquainted with a young lady he described in the following words: "She is such a beauty! so intelligent! so well behaved! And best of all, so sweet and pleasant to me!' $(2: 418)$. The ardent suitor was about to propose when, all of a sudden, he noticed in the girl an "inclination to the Moscow high life and a complete lack of such propensities as I would like to see in my future life companion." In addition to this, he learned that the dowry was not large.

Bolotov's set of requirements had been somewhat unusual in the capitals. It was much more so in the provinces. He was, however, considered a good match, even though both his means and social standing were modest. The local matchmaker, expressing common opinion, commended his respectability, good character, and education. She accepted Bolotov's terms, if slightly eccentric, and tried to meet them. Here is how his friend and neighbor Pisarev assessed his prospects in this field:

In your person, we have now got ... a famous, eligible bachelor such that, as soon as everybody comes to know you better and rumors about your qualities spread every where, many girls will be out there not objecting to marry you, and their mothers and fathers will gladly marry them off to you. But not every girl is suitable for you, so there is no need to hurry. I do not talk about wealth, ... weal th is the last thing to consider, and one could find many girls with some; what you need, though, is a human being, not an animal, for you to live your life together with, and that the other side should have some of the inclinations and gifts you have. She ought to be, for example, a lover of sciences or, at least, 
enjoy reading books so that you find in her a person with whom you could exchange a few words $(2: 358){ }^{76}$

The passage reveals some unusual considerations taken into account while discussing this delicate subject. It should be said in all fairness that Pisarev intended his own sister to marry Bolotov and was doing his best to make up to him, but it is also important that the sister fitted the ideal, if only in her brother's eyes. As Bolotov noted in his memoirs (2: 445), she was, indeed, educated and read books-a case much less extraordinary than it had been several decades before. In the mid-eighteenth century it became regular practice in the provinces to teach daughters to read: ${ }^{77}$ many women of Bolotov's acquaintance in the country were literate, and some of them enjoyed reading. As for young ladies' behavior, it was still somewhat different from that in the capitals: while the Moscow beauties displayed a readiness to socialize, their provincial counterparts remained traditionally shy and silent.

Having found it difficult to fulfill all his requirements (Pisarev's sister had been rejected because of her insufficient dowry), Bolotov decided to realize the last hope he had nurtured under the influence of the Enlightenment: he would marry a very young girl in order to bring her up according to his own tastes. He chose a girl of twelve, consented to defer the wedding for a year so that she could grow up a little, and began making preparations for marriage in his own way (2:434). He started writing his Detskaia Filosofiia (Children's Philosophy) — a didactic work, imitative of Mme. de Beaumont's Magasin des enfants, ou Dialogues, for the purpose of educating his future wife.

Researchers agree that a girl's education in the second half of the eighteenth century was intended primarily to introduce her to the basics of housekeeping and childcare. ${ }^{78}$ Bolotov's pedagogical ambition went much further, his dream being to impart to his wife "the essentials of metaphysics or natural theology" and, only additionally, the virtues of a wife and mother. He added that he had included in his book "the first conversations depicting such a character of a young woman as I would like my future life companion to have" (2: 443). His idea of a good wife combined a set of traditional values with a propensity to sciences. Although not essential, knowledge of atomic theory and familiarity with the law of preservation of matter counted among definite assets. Remarkably, the tutorial, a series of a mother's conversations with her children, did not differentiate between information for the son and the daughter. ${ }^{79}$

Bolotov's future wife Aleksandra, née Kaverina (1751-1834), had seen her suitor not more than three times before the wedding. She was not even old enough to be able to express her own opinion about her future groom. According to Bolotov, the matchmaker told him that "ever since she [Aleksandra] learned of the proposal, she does not even want to look at me or talk to me. No matter what you say to her, she 
either keeps silence or weeps or, all blushing, goes away. None of her relatives could get her to tell what she thinks of you" (2: 489). But this mattered little to her mother, who liked the suitor, nor did it to Bolotov. "Youth is no obstacle at all," he reasoned. "It is much less dangerous for me to marry a young and simple country girl than some fashionable and spoiled coquette from Moscow"(2:444).

The baryshnia displayed, however, the natural reactions of her youth: she was shy, confused, and scared. Once, during an unscheduled visit to her mother's place, Bolotov was given by his betrothed a reception that cooled him down a great deal. Almost half a century later he made a bitter confession:

And I do not know whether it was that ... I saw her too simply dressed and by far less elegant than I was used to seeing her, or that my sudden visit disturbed all of them, her in particular; but, whatever it was, this time she appeared to me in every respect unlike the one I had seen before . . . such that I found no slightest pleasantness either in her countenance or in how she behaved or acted... [R] efusing to return any signs of affection I showed her, she apparently sought to keep away from me, and I could find almost no matters for conversation, as she took no part in it, was taciturn, only answered, reluctantly as well, questions directly asked of her, and displayed no slightest affection for me (2: 520).

This passage describes an encounter with a child rather than an object of courtship. Bolotov was on the verge of backing off from his matrimonial plans but, on second thought, refrained from such a crucial action, for he felt his reputation was at stake. He decided to go through with the wedding.

Soon he found that his dream to educate his young bride was unlikely to ever come true. He later admitted that, his good intentions notwithstanding, she had never developed any interest in his pursuits. A companion to share his interests, however, revealed herself in the person of his mother-in-law. Not much older than himself, Mariia Abramovna Kaverina (née Artsybasheva) had, according to Bolotov, many virtues such as a love of reading, interest in science and gardening, and curiosity about everything new. In a passage dedicated to her, Bolotov praises her friendly attitudes, describes at great length her "greatest and most sincere sympathy" with his ideas and undertakings, and concludes:

that much was quite sufficient for me, for that was the only thing I had been lacking as a bachelor, the only thing I had intended to attain. That was what I found in my mother-in-law, who arranged to live inseparably with us and be the complete mistress of my house until my wife came of age. And that helped me to leniently endure all of my wife's conspicuous weaknesses and to feel not so distressed as I would have been feeling, if I had not had a person to replace them (2:557). 
Bolotov married in 1764; in 1805, while revising the previously written chapter about this event, he added with satisfaction that his mother-in-law was still alive and had been his family's guardian angel for many years, which fact had provided him with "the reason to be happy with my marriage and to thank God" (ibid.). It is hard to believe that this reason for considering their marriage happy was fully shared by his wife Aleksandra, whose position in the family was little changed by her marriage. Permanently present in the house, the mother not only ruled the household but probably supervised, as before, the daughter's behavior as well. Aleksandra's new status as the mistress of the house was but nominal, despite her new conjugal duties, including childbirth.

Like Nepliuev's wife, Aleksandra Bolotova left no documents of her own, so one has to accept what little her husband deemed worthy of his progeny's attention. Bolotov uses a bright palette to describe how much fun his entertainment was to her (and her mother) after the wedding. He reports his taking them out to visit relatives and neighbors, reading aloud to them, inventing domestic games, organizing dances, and so on (2: $662 \mathrm{ff}$.). He readily notices any indication that his young bride is overcoming her total confusion and starts to look up to him. This is how he interprets the animation she feels at the theater and at the balls during their trip to Moscow soon after the wedding (2:665). And he continues in this vein for many pages and years, so as to convince the reader that he, Bolotov, did his best to make his wife happy. He frequently complains, however, about her character, generally sad and indifferent, and about her lack of interest in everything that interested him. No matter how strong an admiration he managed to arouse in his mother-in-law, the knowledge of feminine psychology was not among Bolotov's strengths, so neither in the beginning of his married life nor later did he come to understand his wife. But sometimes he goes beyond bitter complaint and sheds, perhaps unintentionally, some reflected light on Aleksandra's real feelings:

Fallen on the very first day in a sincere husbandly love with her, no matter how I tried to cuddle up to her and much as I sought out and deployed every possible means that could amuse her, cheer her up and make her attachment to me closer, I but very little succeeded in that. She appeared to have a most composed character and to be altogether insensitive to all these things. ... But most importantly, neither could I [gain] from her any slightest reciprocal caresses and such affection for myself, as young wives usually show their husbands in public and in private. No, never in my life have I had this pleasure! (2: 554-55) ${ }^{80}$

Aleksandra's married life must not have been very happy. Pregniant for the first time at fourteen, she gave birth to a son who did not live long. Childbirth at such a young age must have been terrible for her: the suffering lasted for three days and 
nobody believed she would survive (2: 621$)$. Soon pregnant again, she delivered her second child a year after the first. Next year, the third. Between deliveries she suffered from several dangerous diseases which completely undermined her health. Children's illnesses and deaths added bitterness to her life. In this respect, Aleksandra's life was hardly happier or easier than that of Fedos'ia Nepliueva or women's lives a century before. It was, however, much more comfortable and well organized, as her enlightened husband, to do him justice, certainly supported her and treated her fairly, rarely left her alone, provided for the family as best he could, and played an important part in raising the children.

Of nine children borne by Aleksandra, five survived, including four daughtersfuture baryshni. The eldest, Elizaveta (b. 1767, d. after 1820), grew up a sweet and smart child loved by everyone. At five she started learning to read and write, and did so well that Bolotov left a note in his diary about his high expectations based not on the girl's character, but on her advancement in learning (3:106). The younger daughters, Anastasiia (b. 1773, d. after 1820), Ol'ga (b. 1775, d. after 1829) and Ekaterina (b. 1778 , d. after 1808), also learned to read and write at home. As distinct from the usual way of rearing children on a gender basis (mothers dealing with daughters, and fathers with sons), all the adult family members took part in educating them, the grandmother teaching them to read and write, the mother training them in all kinds of needlework, and the father instructing them in science (3: 601, 4: 346). Himself an ardent amateur artist, he also taught them how to draw and paint. Later he bought a pianoforte and engaged a music teacher. Anastasia, a nevesta (marriageable girl) at the age of twelve, went to Moscow where she learned to dance "in order to give her gifts a better perfection" $(4: 70,87)$. Although nannies nursed the children when they were small, the family hired neither governesses for the girls nor a tutor for the boy.

At thirteen Elizaveta was considered a polunevesta (half-nevesta). Her mother made preparations for her future marriage, and her father continued, in conformity to his Detskaia Filosofiia, "shaping her young mind and imprinting it with the necessary knowledge and conceptions of whatever was possible." To his discomfiture, the girl could not be taught languages, "for it was not appropriate for her to be at the pension with the boys, whereas our means did not allow us to have some Frenchwoman or a madame for her alone." ${ }^{81}$ Aside from the shortage of funds, there were other reasons behind Bolotov's reluctance to hire a governess: he distrusted "Frenchwomen" and deemed them to be capable of spoiling a young girl's disposition and demeanor (3: 919).

Bolotov renovated his hereditary estate so that the simple but rather commodious house had, along with a drawing room and a study (rarely encountered at the mideighteenth century), a room for the daughters, if only one initially. Later he built another house with two studies (for the father and for the son), an art gallery, and a separate 
wing with several rooms for the daughters. ${ }^{82}$ Like their father, the young ladies could now enjoy some privacy. Their windows looked onto a beautiful view over the Skniga River meandering through a valley. A landscaped park with terraces, ponds, and shady alleys was located on its steep banks; the house had a flowerbed and a garden laid out in front of it, with the vegetable garden and all the outbuildings hidden behind.

In 1774 the family moved to Kiiasovka and two years later to Bogoroditsk, where Bolotov served as manager of Catherine the Great's estates. There as well, the baryshni's life was filled with the simple joys of living close to nature, learning, reading, listening to music, meeting with relatives and guests. Music, "spiritual, orchestral, and vocal, simultaneously and alternately," in Bolotov's words (4:329), rang every day in the house; "symphonies and concertos" were preferred, but Russian folk songs were also included. The girls played the piano, their brother played the violin, and even their father sometimes accompanied them with one hand. In addition to that, music by a traditional orchestra of serf musicians was available at any time ${ }^{83}$ One can feel the quiet and warm atmosphere of the Bolotov home in a letter Bolotov wrote to his son in 1789: "I am currently sitting in the study, Azorka [the dog] on the stove, Bizhutka [another dog] in the chair.... [Your] sisters exercise in playing pianoforte. Mother is in the bedroom and busy with her own things" (4:601).

With the book trade reaching the provinces in the 1780 s, books began to penetrate the daily life of the nobility. In 1795 Bolotov wrote: "As few libraries as we used to have in Russia, so many of them have suddenly emerged in all private houses." $84 \mathrm{~N}$. M. Karamzin pointed out the same phenomenon in 1802:

\begin{abstract}
We are beyond the times, both propitious and worthy of eternal memory, when the reading of books was the exclusive right of the select people; . . the soft heart of dear beauties finds in books the sensibility and the ardent passions it vainly seeks in suitors; mothers read in order to better perform their sacred duties-and a provincial nobleman's family whiles away autumn evenings by reading a new novel ... Our Homeland is not an exception ... In Russia, the love for reading is spreading around and people have discovered this new, earlier unknown, pursuit for the mind. ${ }^{85}$
\end{abstract}

Great "okhotnitsy do knig" (book lovers), the Bolotov girls inherited their love for reading from their father, who referred to books as "the world's first treasure" (2: 67). He had collected an extensive library of scientific, religious, philosophical, and didactic works, German and French novels, Russian books, and Russian and European magazines. No works by Voltaire made their way into this library, however, in accordance with Bolotov's firm conviction that this author was no less than a "seducer of young hearts." ${ }^{16}$ Extremely scrupulous in selecting books, Bolotov saw to it that his daughters would have access only to works of the highest moral standards, as he understood them. 
Even the long and "boring" autumn months passed "happily" for the baryshni, to judge by the description of how the family spent its leisure hours in 1778. A circle of friends had formed around the Bolotovs in Bogoroditsk. They gathered almost every night, everybody's children coming from the pension, dance teachers and musicians always around, and the young ones dancing as much as they liked. When tired, both the children and the adults played fanty (forfeits). The adults also played "non-ruining and amusing" card games. Neither drinks nor too much food were served. The company had a good time together: "boisterous laughs, jeers, and friendly accord, and everybody's simple manners added to all this a superb pleasure and a sense of genuine enjoyment" (3: 806-08). Such pastimes appealed to the tastes of many nobles in the neighborhood, although there existed alternatives. Two princes, P. I. Gorchakov and F. F. Volkonskii, whose entertainment consisted principally of drinking and overeating, insistently invited Bolotov to join in their company, but he declined to see them often, not being interested himself and considering this inappropriate for the female members of his family (2: 603-04).

In 1777 a theater opened in Tula, and the Bolotovs frequently traveled there to see a play. They also attended performances and masquerades when visiting Moscow. The children were so interested that Bolotov decided to organize his own home theater in Bogoroditsk, which is now believed to be the first children's theater in Russia. ${ }^{87}$ Staging his didactic plays and using his own children as both protagonists and actors, he directly expressed his pedagogical ideas, aimed at "ridiculing, on the one hand, the liars and boasters, the ignoramuses and young libertines, and presenting, on the other, examples of the well-behaved and diligent children, as well as their virtuous deeds" (3: 872).

The protagonists of one of those plays, Chestokhval (1779), the landowner Blagonravov's son Kleon and daughter Feona, bear the names of the boy and the girl in Detskaia Filosofiia. Like Elizaveta, who played her, the thirteen-year-old Feona is considered a nevesta and views herself as quite an adult. Her upbringing conforms with the old tradition, which arouses the disapproval of Chestokhval, a young dandy, rogue, braggart, and Gallophile: "You deem everyone to be thus sitting locked in, as you and your father are. No, madam! not everybody cares that little about what is inherent and appropriate to their noble status! Presently, the ancient customs are becoming out-of-date and nobleness is no longer in fashion." ${ }^{88}$ Chestokhval is about sixteen or seventeen years old and engaged to a Mr. Neugomonov's daughter, but his true target is the Blagonravovs' maid Marfutka with whom he tries to arrange a secret tryst; when punished for his lies and arrogance, he plans to seek revenge on his wouldbe bride and father-in-law: 
And it's then that they'll come to know me-and I'll show my artfulness to the bride. But she is a fool, isn't she! She won't even understand. Why not marry her just to take away her villages and bamboozle the blockhead father-in-law out of his money! They say he's wallowing in it-everything will be ours. And then we'll cut a dash and have some fun! As to her, a man couldn't care less about her being so ugly and stupid! Her maid is almost as good as Marfutka, and it doesn't take much, after all, to pick up Marfutka too! ${ }^{89}$

In Neschastnye siroty (Unhappy Orphans) (1780), baryshnia Serafima and her young brother live with their distant relative Zloserdov, who intends his son to marry the girl in order to appropriate the orphans' property. Once again, Serafima stands for the young Elizaveta Bolotova who played her on stage. The virtuous girl, "a true angel" in a servant's words, exemplifies all the good qualities in the spirit of Rousseau, Bolotov's favorite author. Having a "humane heart combined with a sharp... mind," Serafima is modest and humble, makes good as best she can, helps the poor, and finds consolation from her continuous misfortunes in reading useful books and being close to nature. Her two favorites are Khristianin v uedinenii (A Christian in Solitude) and one about nature's sublime beauty, that is, books treating what Bolotov regarded as the most useful and ultimately important sentiments to be inculcated in his daughters. $^{90}$

In the process of bringing up his daughters, Bolotov's conception of a virtuous wife had undergone some modifications. Before his marriage, Feona in his Detskaia Filosofiia expressed his own expectations for a humble wife: "Oh mother, so ... if I ever marry, I shall not grumble at anything to my husband, no matter how he is toward me; but I shall constantly remember that God has thus willed." 91 Twenty years after, Bolotov sympathizes with his fictional Serafima's reluctance to marry a rascal and a villain. A noble count appears in the play, marries her, and saves the humiliated orphans. Thus, a former seeker of humility and obedience in his own wife, Bolotov regards his beloved daughters from a more enlightened point of view. This attitude seems to conform with the then nascent "male ideal" (so attractive even now!): a submissive wife versus a more independent, happier daughter.

When giving his daughters in marriage, Bolotov looked for good, modest men and did his best to satisfy the baryshni's feelings and preferences. This would not include, however, allowing some time for the young couple to get to know each other, for even such an enlightened father as Bolotov considered it unnecessary. The girl would only be asked whether or not the suitor was not protiven (repulsive) to her and, if not, the decision was up to the parents. Obviously, this kind of arrangement had little new to it. Somewhat novel were the criteria used to assess the prospective grooms. By rejecting a kartochnyi bogach (rich man who won his money at cards) who had proposed to Elizaveta, Bolotov proved that wealth was not his first priority. Whenever 
a suitor appeared, both the parents and the girl would try to learn about his "mind, knowledge and, to a degree, his character." Anastasiia's groom revealed an "inclination for literature and art most of all appealing to us" and won unanimous approval (4: $335,1114,1115)$. The Bolotovs also departed from the archaic custom in which parents almost completely severed ties with a married daughter -otrezannyi lomot' (cutaway chunk) - as soon as the husband took over from them as her ultimate master. Reciprocally, the Bolotov girls were closely attached to their parents, and the relationship lasted long after they left the nest.

In Bolotov's plays about "correct" life, both the characters and the audience unmistakably distinguished good from evil, as honest virtue inevitably triumphed over disgraced vice. But reality is never so simple. After several years of his daughters' married life, Bolotov wrote:

\begin{abstract}
As to both my married daughters, the elder one, Elizaveta, continued to live well with her husband and was ostensibly happy, although to no small extent anxious about his not altogether soft, sometimes vehement disposition, and even more so about his frivolity and excessive propensity to splendor, extravagance, and prodigality, possibly conducive to extremely grave consequences given their means. However, she was glad not to be pregnant this year. They had only one son left alive, Nikolai, who had lived with us and been raised by us since his birth. He was at that time our everyday doll, our delight, our toy and our joy. . . . My other married daughter, Nastas'ia [Anastasiia], was already pregnant about that time . . . and lived with her husband more quietly and peacefully, even if not so sumptuously; her only concern was about their disorderly circumstances and their debt, depressing even though not large $(4: 1221-22) .^{92}$
\end{abstract}

The parents' hopes and the daughters' expectations only partially came true.

\title{
The Bitter Consequences of the Enlightenment
}

\section{Anna Labzina, née Iakovleva}

Some researchers deem the life of Anna Evdokimovna Labzina, née Iakovleva (1758-1828), to be that of a martyr, others consider it worthy of a soap opera. ${ }^{93} \mathrm{Her}$ tragic experience demonstrates how bitter a fight the old principles sometimes waged against the new ways of life. Labzina's memoirs are a real treasure for this essay, for they present a woman's voice sounding for the first time in full strength. Composed in the tradition of hagiography, the memoirs tell of a young girl's martyrdom in the 1770s, as seen by herself almost half a century later. Describing her arranged first marriage, which brought her nothing but disappointment and despair, Labzina spares no black 
colors in portraying her dissolute husband, whom she believes to have made all her life miserable.

Labzina's memoirs present, on the face of it, a striking contrast to those by Bolotov, the authors having opposite purposes and emphases. But reading Labzina after Bolotov, one cannot help noticing that her text fits perfectly with many topics, deliberately or unintentionally passed over in silence by Bolotov. The setting is virtually the same and rather typical of the time - a newly started family that consists of an extremely young, ingenuous baryshnia and a man twice her age, far superior to her in life experience, education, maturity of judgment, and so forth. We are already familiar with Bolotov's wife as perceived solely by him; now we find that Labzina's voice can, to a degree, substitute for Aleksandra's and explain some of the reasons behind Aleksandra's frigidity and bewilderment. If cautiously interpreted, this juxtaposition of the two narratives provides clues to some essential aspects of life common to many of their female contemporaries.

Born into a noble, patriarchal family in Ekaterinburg Province, Anna spent her childhood on a family estate in the country. Her mother inculcated in her a deep religiosity, obedience, and respect for her elders. Referring to her childhood, Labzina wrote: "Speaking of myself, I can say that my own will never mattered: even my desires were only those pleasing my dear and respected mother" (9). Her mother, in turn, treated Anna in a traditionally rigorous manner: the daughter's good demeanor was never encouraged beyond a blessing and permission to kiss her mother's hand. ${ }^{94}$

The entire rhythm of the girl's life prepared her for marriage. In summertime the nanny used to wake her up before dawn. She bathed in the river and then prayed on her knees, her face turned to the rising sun. Back home, she was served hot milk and brown bread, tea being considered an inappropriate luxury. In her leisure hours, she walked and played alone in the woods. Many acquaintances reproached her mother for bringing her up in too stringent a manner, the mother's answer being, "I do not know what her circumstances will be; she might find herself poor or marry someone with whom she would be compelled to travel: so she shall never bore her husband and know what a fancy is, but shall be happy with everything and endure everything: frost and squalor, and will never even catch a cold. And if she is rich, she will easily become accustomed to the good" (6).

There is a remarkable similarity between this traditional view about rearing a girl and the then fashionable system derived from Rousseau. This paradox was, however, soon to be overcome so that "ultranatural" education would become old-fashioned and even "base." For example, Mariia Kamenskaia (1817-1898), the painter F. P. Tolstoi's daughter, recalled that as a girl she used to spend most of the day in the fresh air, liked to run, readily worked in the garden, and rarely ate anything but brown bread. This upbringing, named by Kamenskaia both "ultranatural" and "in the Russian 
manner," "scandalized" the local populace who expressed their indignation in the following words: "This is unheard-of! What a mongrel she looks like, and this is a count's daughter! What a shame, real shame!"95

Anna Labzina's education did not go beyond the patriarchal tradition. Under her mother's guidance, she knew how to read and write at the age of seven, at which point the studies stopped. After that her mother would only teach her needlework and "educate her heart," mostly by example. They spent much time visiting the poor and needy, as well as the inmates of the local prison. They fed the hungry, distributed clothes and medicine, dressed wounds, and consoled the dying with prayer and religious conversation.

Suffering from a fatal disease, the mother hurried to arrange Anna's marriage to Aleksandr Karamyshev (1744-1791), a close friend's son. It never even occurred to the mother to ask the thirteen-year-old girl's consent, but she gave her the following instructions quite in the spirit of Bolotov's Detskaia Filosofiia: "Love your husband with a pure and fervent love, be obedient to him in everything: not to him shall you submit but to God,-it is God who will have given him to you and appointed him master over you. Even though he behaves badly toward you, you shall endure everything patiently and make up to him, and never complain to anyone" (21). Anna was ready for obedience and even sought to be guided. Missing her dead mother, she developed a strong attachment to her mother-in-law and relied on her advice. Her dream was to find in marriage the same love and security she had experienced in her own family, but she knew nothing about married life, its intimate side in particular. On finding soon after the wedding that her husband's niece slept in his bed, she was not even able to grasp the real reason behind this circumstance. Soon disappointed in her husband, she complained, without any reference to his sexual misdemeanor, about his lack of parental love for her: "They told me my husband would love me not less than my mother had" (25).

A wife-child brought up among traditional values and beliefs, she was incapable of understanding her adult husband with his new-fashioned views on both life in general and marriage in particular. Never allowed to read a novel or see a play, always isolated from her peers, she knew no feelings but love for her parents. Once in St. Petersburg, she became interested in a young relative of her husband's but never realized the nature of her feelings. Her host, the writer M. M. Kheraskov, who cared for her with almost paternal sympathy, understood from her remarks what was going on and did his best to prevent a romance from developing. Innocent and obedient, Anna easily and even gladly followed her mentor's advice (53-56). In her devoutness, she regarded even her husband's overt unfaithfulness as no more than a transgression of the vows he had made to God. The following is her description of one of their painful scenes: 
Finally, he was compelled, through some commissions from his superiors, to spend more time at home; but he looked constantly bored. However frequently I asked him why I could not sweeten his life and whether he liked it better with strangers, he only answered: "Is it that you really think I can substitute for you those whores you are talking about? You are always my wife and friend, while those are for pastime and pleasure." "... but this turns out to be carnality and sin against God and breach of vows you made to me on the holy script! Beware, my friend, of God's justice lest it punish you!" He laughed and said: "You are so sweet when you resort to philosophizing! I assure you that you apply the name of sin to what is nothing more than natural delight, so I am not subject to any responsibility" $(77-78) .^{96}$

Here we see a striking tangle of attitudes at opposite poles. Anna felt truly humiliated and unhappy. Her husband was rude and unkind to her, spending little time at home, making no secret of his love affairs, and losing at cards the money she had brought to him as her dowry. These are some of the accusations Labzina made later against her husband in her memoirs, unburdening herself of her poignant memories. Narrated with bitter sincerity, her story depicts a lonely and desperate young woman who must have suffered deeply and genuinely. There likely was, however, another side to this very personal picture. The young wife had no notion of her husband's scientific and public activities and pursuits, nor did the mature memoirist reveal any interest in her late husband's personality.

As to Karamyshev, objectionable as his behavior looks, it could be viewed from a slightly different angle. In the second half of the eighteenth century Russian society still did not strictly connect sexual relations to marriage. More than once foreigners expressed surprise at the Russian empresses' overtly amorous adventures, which had the effect of legitimizing extramarital affairs. ${ }^{97}$ According to a contemporary, "at that time it would even appear ludicrous that one lived happily with his wife and remained faithful to her." 98 Before 1762 , the majority of noblemen were separated from their families, often for years, and many of them developed a sort of self-indulgent permissiveness which contributed to society's liberal attitudes toward sexual promiscuity. Women in noble families were much less exposed to such situations and ideas, as they seldom traveled and never read much beyond what was approved by their parents or husbands. The fact that wives would put up with their husbands' sexual escapades illustrates the inferiority of their position in the patriarchal family rather than the emergence of any new trends in public consciousness.

On the one hand, society did not really disapprove of well-to-do men's promiscuous intercourse with serf girls. Both Anna Labzina's mother anu mother-in-law tumed a blind eye to Karamyshev's adventures; he himself must have considered sexual misdemeanors as quite forgivable. On the other hand, marital relations rarely provided 
any delight, either emotional or sexual; moreover, religion regarded sexual enjoyment as sinful. ${ }^{99}$ Marriage without knowing each other beforehand, often based on material considerations, did not presume any mutual affection. Associated with God, love in marriage was not connected with sex. Thus, the fact that Karamyshev drew the line between sensual pleasures and matrimonial duties was by no means new, but his arguments were.

Naslazhdenie natural'noe (natural delight), mentioned by Labzina's husband, connotes Rousseau's idea of natural joys. In his own way, Karamyshev respected his wife's freedom of choice and even suggested, in conformity with the ideals of the Enlightenment, that she find herself a lover in order to learn about the joys of life. Moreover, feeling himself responsible for his innocent wife's education, he offered his assistance in her selection of a worthy candidate for this purpose. Scholars have noted that ethical experiments like this, when carried out in real life, frequently came to mere licentiousness. ${ }^{100}$ And yet, let us compare Karamyshev's ambiguous conduct, viewed by his wife as depravity, with that of the highly righteous Bolotov. ${ }^{101}$

Bolotov, deeply religious and in all ways worthy of Labzina's approval, married and immediately made his child bride his de facto wife. In less than two years she delivered her first child and gave birth almost every year thereafter. At the age of twenty two she was suffering from an acute uterine disorder and remained a martyr to it for the rest of her life. Undoubtedly, early sexual activity and childbirth-the groom himself called her sushchii rebenok (mere child) at the time of the proposal -had contributed to this suffering. Bolotov expressed compassion for his wife but, quite in the spirit of his time, never stopped performing his conjugal duties.

Karamyshev, ostensibly opposite to Bolotov with respect to his morals, also married a thirteen-year-old girl because of her dowry and to fulfill his late guardian's (her father's) will. He did not exhibit model behavior, but at least he showed consideration for her young age. Both our heroes attempt to raise their ingenuous wives to their own level. However, while one starts to zealously instruct the girl in sciences and simultaneously has sex with her; the other spares his wife's innocence by making her only watch him have a good time with the maid (presumably, to teach her a lesson in an area of which she was completely ignorant). The distinction between vice and virtue becomes less clear and definite in the light of this comparison. Moreover, both these types of behavior comply with the moral norms of the epoch, however wide of the standard they might appear.

The villainies Labzina blamed on her husband pale even more if one considers that their twenty-year marriage remained childless. However hostile toward Karamyshev, her narrative makes it clear that he was deeply upset and considered himself responsible. This explains his insistent recommendations that Anna take a lover, so that he could adopt and raise her child whose origin he would keep secret (94). In 
this respect, his views look much more liberal than those Bolotov expressed in 1822: "Many people are born without the rite of matrimony established by God or from fallen women who illegitimately conceive children, and ... on such occasions, God should by no decent means foster the creation of new creatures." 102 This statement would have better befitted the man who stated in the middle of the previous century that "it is better for children born out of marriage to be in the Moskva River."103

Concluding this comparison, we cannot help surmising that, had Karamyshev undertaken to describe his life, his autobiography might have resembled Bolotov's memoirs. The settings of their lives were similar: a modest provincial nobleman, Karamyshev also rejected a military career and devoted himself to science and intellectual activities. A prominent mineralogist and engineer, he also had a sense of civic and professional duty, read the same books, and was exposed to the same ideas as Bolotov. Although not an exemplary husband, he showed some repentance for his misdeeds, as Labzina herself admits. Obviously, there were differences between the two men-in disposition, temperament, and behavior - but it is highly doubtful that Karamyshev ever perceived his own self-indulgence as vice.

In turn, had Aleksandra Bolotova chosen to write her memoirs, she could probably have told us no less bitter stories about the early years of her marriage than Labzina did. Her life with an intelligent and self-righteous husband may have turned out to be neither easier nor more pleasant. With his meticulous attention to every detail, sometimes irrelevant to his own narration, Bolotov portrays a sickly woman, seldom smiling, bored with her husband's activities, and yet indulgent, silent, and obedient. Equally silent when a young wife, Labzina spoke out much later, after she gained in her second marriage an experience dissimilar from her first one. Three years after Karamyshev's death Anna married Aleksandr Labzin (1766-1825), then junior government official, who later became a prominent Freemason and founder of a Masonic lodge and a mystical journal. Sharing his interests, Anna enthusiastically helped him in all his endeavors and was, apparently, happy in this marriage of thirty years. Bolotova's life turned out differently: she spent seven decades by her husband's side, saw little beyond country life (of which she enjoyed all the comforts), outlived most of her children, and died peacefully amidst her family. "Habit is given to us from above, it is a substitute for happiness"- - this Pushkin (after Chateaubriand) maxim perfectly fits her life.

It is important to note that neither woman displayed unwillingness to surrender to the husband's will. On the contrary, in strict conformity with their patriarchal upbringing, both girls - still children when given in marriage - expected nothing from their husbands but some guidance and care. And yet, all the differences between Karamyshev and Bolotov notwithstanding, the beginnings of family life must have appeared rather sad to both of these baryshni. No spiritual, emotional, or cultural bonds between 
them and their husbands; no knowledge or experience to bridge the gap; total ignorance about sex-these factors, to name a few, were sufficient to ruin their prospects of happy marriage. No matter what subsequently befell them, Anna Labzina's bitter moan from the depths of her soul could probably have produced an echo in Aleksandra Bolotova's heart, as well as in the hearts of many of their female contemporaries.

\section{A True Realm of Women}

\section{The Bunin daughters}

The moral ease that characterized the later eighteenth century is amply illustrated by the situation in the prominent Bunin family. ${ }^{104}$ Afanasii Bunin (1727-1791), the voevoda (military administrator) of Belev in Tula Province, a rich and influential nobleman, a friend of the Orlovs, was the most important person in the district. His four legitimate daughters grew up together with his illegitimate son Vassily Zhukovsky, the future poet. The family was a true zhenskoe tsarstvo (women's realm), the daughters largely determining its atmosphere. The young girls took for granted that their father lived in a separate wing of the house with his concubine Sal'kha, a captive Turk woman who was Zhukovsky's mother. Even their own mother, Bunin's wife Mar'ia Grigor'evna (?-1811), a woman without prejudices, according to those who knew her, regarded the situation as tolerable. ${ }^{105}$

The daughters inherited their parents' tolerance: three of them would raise natural children in their families. ${ }^{106}$ Not only did the daughters grow up in an adulterous situation, but their own extramarital relationships, when they were considered likely to provide social benefits or material advantages, met with support from their parents. Natal'ia Bunina (1756-1785) was widely known as the mistress of M. N. Krechetnikov, namestnik (governor) of Tula and Kaluga. Provincial society did not object to it, in contrast to the virtuous moralist Bolotov, who thus described his encounter with Natal'ia Bunina at Krechetnikov's:

I saw quite enough of this lady, who played a significant part at that time, and I could not marvel enough at her husband, who felt no scruples at his being but nominally the husband and sacrificing his wife to the pleasure of this grandee. But it was not so much he who amazed me but this lady's father. He was a Mr. Bunin and served at that time as gorodnichii [town governor] in Belev where the namestnik had met this family. There were rumors that both the father himself and the mother of this lady, then unmarried, had contributed to this kind of relationship between their daughter and the namestnik, with the only purpose to enjoy his favors. And in order for him to have her constantly within close distance, she had promptly been married off to a young man, from the Vel'iaminov family, whom the namestnik promoted according to the occasion 
and who too played, as his counselor, a significant part at the time (3:118586). ${ }^{107}$

This was not an uncommon occurrence in eighteenth-century provincial Russia: the role of mistress conferred high social status upon a lady, since the public tended to credit her with some influence over her lover. The lady's husband - there usually existed one - could also attain some power and glory in her shadow. On another occasion, Bolotov described the colonel of his regiment as openly having an affair with the wife of his assistant, while the latter remained "the mainspring of the entire regiment's administration" and stood high in his fellow officers' esteem (1:274). Such special circumstances could indeed turn a woman into a provisionally powerful figure, but just this very fact clearly reveals the ambiguity of her position and her complete dependence on the man by her side. This kind of social achievement had nothing to do with any improvements in women's social standing in general.

Bunin's other daughter, Varvara (1768-1797), married Col. P. N. Iushkov (1753?-1805), a refined and well-read man, pianist, and owner of a large and meticulously selected library. ${ }^{108}$ They settled in provincial Tula where she became a woman of the world. Well-educated, beautiful, a talented musician and artist, Varvara soon turned her home into what Bolotov called "the best and most pleasant in all of Tula" (4: 1179), an object of pilgrimage for the local elite. Zhukovsky, who lived in this house as a child, later recalled that "[s] he had something poetic in her. ... Many undeveloped talents lurked in her. This amazed me then, uneducated as I was. I remember even now the way she used to tell stories." 109 Provincial intellectuals gathered in the Iushkovs' house for musical soirées and literary readings, Karamzin and Dmitriev being the favorite authors. Bolotov, who knew the family intimately, referred to the hostess as "a young and very intelligent noble lady, curious and sweet" and "this noble lady deserving respect and love" $(4: 1106,1165)$. He also recalled a soirée in 1794:

I called on Mr. Iushkov and found at his place such a concert as I had never before had an opportunity to attend. So I spent the entire evening and had supper there, and I can say that that day was one of the most pleasant in my life (4: 1150).

The Iushkovs had four daughters of their own; in addition, five more girls, their poor relatives, lived in the family. The parents considered it their duty to provide all the girls with a good education. Since 1786, there had been a narodnaia shkola (public school for the people) in Tula; several pensions and home schools for noble children had also recently opened. ${ }^{110}$ Girls were allowed to enroll in the narodnaia shkola, but noble families preferred to send them to private boarding schools or use tutors. The school that the Iushkovs organized in their own house was attended by sixteen female 
and male students, including Zhukovsky. F. G. Pokrovskii, doctor of philosophy, instructor at the narodnaia shkola, historian, and author, taught Russian, arithmetic, history, and geography, while a governess taught French and German. A children's theater staged plays, including Zhukovsky's first ventures, and children's parties were given at the Iushkovs' twice a month. Since Varvara Iushkova took an active part in the management of the theater in Tula, the girls had permanent access to the performances. " The habit of theater-going-" the usual time for theater" in a contemporary's words-was winning its place among provincial pastimes. ${ }^{112}$

Such an environment proved beneficial for the baryshni's progress. The education and upbringing the Iushkov girls received would allow them to join the most select intellectual circles. P. Bartenev, who later knew one of them, Avdot'ia, wrote that she had grown up in a family that "lived in perfect prosperity, even somewhat to excess, which imparted a happy steadiness to their circumstances and gave scope to all kinds of growth." 113 In reality, the family's financial situation left much to be desired: two of their villages in Belev district had to be mortgaged in 1796, and the following year the authorities temporarily seized the property for nonpayment. ${ }^{114}$ The parents did their best to insulate the girls from those mundane concerns.

In 1797 Varvara died of tuberculosis at the age of twenty nine. Iushkov moved with his four daughters to his mother-in-law's estate of Mishenskoe. Three daughters of the deceased Natal' ia Vel' iaminova (former governor's mistress) already lived there. Soon the youngest of Bunin's daughters, Ekaterina Protasova (1770-1848), recently widowed, also came to live there with her daughters Mariia (Zhukovsky's passion for many years to come) and Aleksandra (prototype for the heroine of his ballad "Svetlana"). Nine baryshni gathered in the house under the grandmother's unquestioned authority. Iushkov was managing the property; another male figure in the zhenskoe tsarstvo was the young Zhukovsky, everybody's favorite, whom all the females indulged in everything.

The girls grew up in an atmosphere of freedom and romanticism. Zhukovsky's Turkish origins, along with their numerous French governesses' stories about the horrors of revolution, excited their imagination. The family spent the major part of the year in the country, moving sometimes to Moscow in winter. All of the baryshni passionately loved the Mishenskoe estate which contributed so much to the shaping of Zhukovsky's talent. The balconies of the large mansion gave onto a broad vista of the ancient town of Belev, its majestic monasteries standing on a high hill at the confluence of the rivers Oka and Vyra; a spacious park with ponds and hothouses, as well as a large garden, completed the landscape.

Zhukovsky, the only young man in the family, had to be formally educated, so he soon left the nest for the Moscow University Pension. The girls stayed in the country, moving from one estate to another, together or separately. A collective letter, started 
by Anna Iushkova and continued by her sisters and grandmother, describes to their beloved Vassily some aspects of the life on the estate:

The very day of your departure we moved into a wing where everything is in
good order. You would yourself tell us the same if you could see us in our new
place. Grandmother's chamber, that is, her bedroom, is in a small [room] at the
corner, your mother is in another small [room], and all three of us sleep in the
[room] where you used to work; there is my sofa in our living room between
two windows which look out at the flower bed, the pianoforte [stands] at the
wall without windows, there are seven chairs, two bureaus, two mirrors, and
three pictures. This looks much like a furniture shop, but everything is in place.
We serve ourselves tea, taking turns every week, work and read, go to see our
aunt twice a week-and that is it! Lord help us celebrate your birthday
together. ${ }^{115}$

Probably a shortage of funds made the family move from the large mansion to the less commodious wing. Notably, the arrangement of rooms looks quite traditional: while the elder women have their private bedrooms, the girls share one. Privacy for the girls was not deemed necessary, but none of them expressed any discomfort about it. Pleasant if modest, the interior of the house imparted some warmth to the atmosphere in the family.

One of the girls later portrayed her grandmother as "a woman of rare education, for she used to read everything printed in Russian, but she knew no other language. She was extraordinarily intelligent, and in nobody else did I ever meet such kindness, benevolence and patience." 16 While speaking no foreign languages herself, the grandmother considered this kind of knowledge indispensable for the young ones and spared no expense on governesses. The issue of the French language in a baryshnia's education is worthy of some special attention.

It is generally known that after the penetration of French literature into Russia in the 1760 s and 1770 s, French came into vogue among the Russian nobility, and a good command of French became a feature commonly ascribed to them. Widespread among some semiliterate nobles, gallomania - the superficial knowledge and blind imitation of everything French--became the subject of well-known satires by N. I. Novikov and D. I. Fonvizin. It is important to note, however, that this phenomenon exerted some influence on concepts of daily life and the issues concerning marriage. The following dialogue between two characters in Fonvizin's The Brigadier puts forward the play's basic theme:

The Counselor's Wife: Ah, our daughter's luck is so great. She is going to marry one who has been to Paris... I know quite well enough what it means to live with a husband who never went to Paris. 
The Son: Madame, I thank you for your courtesy. To be honest, I'd like myself to have such a wife as not to speak with her in any language other than French. Our life would flow much more happily! (Act 1, scene 1)

Several decades later, in Gogol's Marriage, two suitors speaking no French themselves agree that the would-be bride ought to speak it, or "otherwise everything must be wrong with her" (act 1, scene 21). These and many other examples demonstrate that the knowledge of French became and long remained, in the public eye, indicative of a girl's refinement and education-factors of increasing significance among other matrimonial considerations.

Describing the Bunin family as one "where the knowledge of exemplary French philology was so strong and where French émigrés taught," Bartenev would thereby explain its members' astonishing language proficiency, even in an almost completely French-speaking milieu. ${ }^{117}$ In addition to French, the Bunin baryshni thoroughly studied several other foreign languages, history, geography, and literature, both Russian and European. The following 1806 letter by the thirteen-year-old Mariia Protasova to her cousin Avdot'ia Kireevskaia presents the usual curriculum of their classes:

On my own I read Les contes moraux de Miss Edgewort [sic], with mother Roman history every other time, with Masha [her aunt] Adèle et Théodore [by Mme de Genlis], with Sasha [her sister Aleksandra] Goldschmidt's Greek History. In Russian with mother-Anakharsis [by J. J. Barthélemy], with Natal'ia Andreevna [Azbukina, her half-sister] the Bible. ... In German my reading of poor [William] Coxe still drags on. And I write: geography, poetry in French, Roman history in Russian, and various anecdotes in Italian (iv).

When Zhukovsky came back from Moscow in 1805, he immersed himself once again in the wonderful world of the baryshni and their innocent pastimes. Endless literary games, musical evenings, and theatrical performances alternated with horseback riding and picnics. With Zhukovsky's assistance, the girls composed and "published" handwritten, humorous magazines filled with poems, jokes, and descriptions of celebrations and performances. Albums and diaries were in great favor as well. Socializing with noble neighbors was also essential to their lifestyle and played an important part in their everyday activities.

In a letter to Zhukovsky around 1813-1814, one of the young women of the family, the already widowed Avdot'ia Kireevskaia, thus described their life: "We live, as before, within four walls: going from Mishenskoe to Dolbino, from Dolbino to Mishenskoe, from Mishenskoe to Ignat'evo, from Ignat'evo to Mishenskoe, from Dolbino to Volod'kovo, from Volod'kovo to Dolbino, from Dolbino to Chern', from Chern' to our place, and all those extravagances; so the legs that yet carry us are the very same that did in your presence." 118 Here Avdot'ia refers to her own country 
estate, Dolbino, and the neighboring estates of their relatives and friends: Ignat'ievo belonged to the Iushkovs; Volod'kovo to the future Decembrist A. I. Cherkasov; Chern' to the writer and composer A. A. Pleshcheev. Also, they often visited the historian K. D. Kavelin's Ivanovo and some other neighbors.

The Bunin ladies and girls especially enjoyed visiting Chern'. Rich, gregarious, and hospitable, the landowner Aleksei Pleshcheev (1772-1862) wrote poetry in Russian and French, comedies, operas, and romances. ${ }^{119} \mathrm{His}$ beautiful, joyful, and talented wife Anna was everyone's favorite. A multitude of musicians, artists, magicians, and stagehands helped to arrange all kinds of amusements. Every night there was lively society, music, performances, dances, or games. One of the frequently played games, secrétaire, consisted of answering questions picked at random and required much knowledge and wit. ${ }^{120}$

It is impossible to trace in this essay the lives of all the baryshni who took part in this whirl of social and family engagements. Their common starting point was the village of Mishenskoe in the 1800 s, but their destinies were as diverse as life itself. I will present just four of the brightest of those destinies: the two sisters Protasov and the two sisters Iushkov. These four lives seem to span a broad spectrum of possibilities open in the beginning of the nineteenth century to young girls who were relatively well off, beautiful, and well educated.

\section{Mariia Moier, née Protasova}

The characters of Mariia Protasova (1793-1823) and her sister Aleksandra (1795-1829) took shape under the strong influence of Zhukovsky, who played an important part in the zhenskoe tsarstvo of the Bunin family. A participant in all the joys and sorrows, he also linked this small world with the great world of professional literature and art. He gave direction to the girls' education and personally supervised that of the two sisters Protasov, whom he distinguished among all his nieces. The relations among these three people constitute a special page in Russian cultural history.

Soon after returning from Moscow in 1805, Zhukovsky offered his services as a teacher for Mariia and Aleksandra and drew up a detailed program of the course. Ekaterina Protasova, their mother and his half-sister, accepted the offer and invited him to stay with them, first at her house in Belev and then, from 1810, at her newly built estate, Muratovo, in Orel Province, not far from Mishenskoe. While the Protasovs and Zhukovsky remained welcome guests in Mishenskoe at all times, other women and girls of the family often came to stay at Muratovo. To ail of its inhabilianis, Míuaiuvo became symbolic of happiness. In a 1811 poem Zhukovsky wrote: 
Quickly, quickly I must go

To the village of Muratovo.

Happiness has established there

A colony of joy;

Days flow faster there

In between business and idleness. ${ }^{121}$

Zhukovsky planned his course for several years of study, during which the students would eventually acquire thorough knowledge of foreign languages, literature, poetry, history, geography, natural sciences, rhetoric, logic, philosophy, theology, ethics and aesthetics, pedagogy, and painting. ${ }^{122}$ The ordinary contemporary ideas about women's education aimed at improving their ability to properly supervise a household and raise children. In contrast, both Zhukovsky's theoretical system and his practice endeavored to develop a girl's mind and soul, so that she could be useful to society. In his lessons and, later, in his letters to the sisters and their cousins, Zhukovsky expanded on the metaphorical idea of a human being serving others by lighting lamps to illumine the darkness of life. The destiny of a person is to be such a light for others (36). Intertwined with religious postulates, the ideals of lofty civic service became integrated into Zhukovsky's model of personal happiness. "We are in this world not for what the simple, rude, sensual people call happiness but for humility only," he wrote. And in another letter, "I have long ago given another name to happiness. I call it duty" $(119,45)$.Later, serving as tutor to the heir of the Russian throne, Zhukovsky would expound his main pedagogical idea in the concise formula: "All predestination and dignity [are contained] in two words: God, duty."123

Although "predestination and dignity" suggest no division along gender lines, men and women achieve them, according to Zhukovsky, in different ways: while a man's main concern should be his service, a woman's role consists in teaching her children and caring for the needy. This social role rejects neither the hagiographic tradition (compare to Labzina's upbringing) nor contemporary didactics, but the duty to serve society being proclaimed as the goal of a woman's life placed her, in the public eye, level with a man. Zhukovsky's ideas expressed society's new attitude that raising up future citizens for the Fatherland was no longer a completely private matter.

The first word in the formula "God, duty" was not just a figure of speech or a tribute to established tradition. Profoundly and sincerely religious, Zhukovsky interspersed his lessons with references to the transience of human life, to the vanity of pleasures and joys, and to God as the eventual redeemer of all earthly efforts. Both sisters' albums, diaries, and letters are full of notes that reflect these ideas. Right in the middle of her studies with Zhukovsky, fifteen-year-old Aleksandra writes in her album: "To die is the only hope that unhappy mankind still has." ${ }^{24}$ Ten years later, a twenty seven-year-old Mariia, married and anxious about her first childbirth, refers to 
death as a relief in an 1820 letter to her cousin: "[H] ow I will love you then and how we will love each other. All night long, I was thinking about you and wishing - to you and to myself-death!" (243). Earlier, in an 1815 letter to the same cousin, not only Mariia's thoughts but the very language are redolent of Zhukovsky's lessons: "Thus, my friend, one can and has to turn one's life into something significant, without happiness, without excitement, but simply filled with duty. This life must be important, it shall lead to the eternal one! Then what to fear? what to complain of, what to worry about? Happy is one who is ready for anything and expects everything from God" (144).

Unlike most of his predecessors, including Bolotov, Zhukovsky not only advanced a didactic theory, but also successfully put it in practice. His ideas received universal and even official recognition; the emperor himself chose him as tutor to his children, first the grand duchesses and then the heir. Zhukovsky's first female students, the two Protasov baryshni, became the embodiment of his ideas. Literally shaped by him as a teacher, the personalities of both sisters ranked among the most sublime creations of his endeavors, an Enlightenment dream come true. Yet the ideal setting turned out to be a predicament for the creator himself. He noted in his diary as early as July, 1805: "What is happening to me? Grief, anxiety in my soul, some unknown feeling, some vague desire! Is it possible to fall in love with a child? But in my soul, there is a change toward her! For three days I feel sad and despondent. Why? Because she left!"125

Zhukovsky's niece Mariia, the object of his "unknown feeling," was to become his Galatea. She was only twelve, when their sad love story began. He soon recognized his passion and, silent about his love, stayed for years beside her, imparting to her the best of his creativity, shaping her according to the most elevated ideas of his time, and cherishing the illusory belief that some day he might reap where he had sown: "I would be happy with her, certainly! She is clever, sensitive, she would learn the value of happy marriage and would not seek the diversions of the beau monde life. But can it be possible?... Can K. A. [Katerina Afanas'evna, Mariia's mother] really sacrifice both my and even her daughter's happiness for the false reasons and controversies of her pride, for she [Mariia] would indeed be happy with me." 126

Zhukovsky's fondest hope never materialized. He closely guarded his secret, but eventually his love became known to Mariia's mother, who put an end to her daughter's studies with him. She was absolutely furious and held firm to her conviction that the blood relationship between the couple was too close to allow them to marry. Zhukovsky would not give up and kept proposing. In 1814, after several attempts, the question of marriage became completely closed. Ekaterina Protasova was adamant. Here is a sample of her reasoning to convince her many relatives of the propriety of her decision: 
As to Masha [Mariia], I assure you that not only is she not, even now, in love but also unhappy to find in love with her a man she is used, since early childhood, to loving; and, were she confident that he was willing to overcome himself, care for his own health and work as usual, she would long have calmed herself and would by no means ever wish for this marriage, having learned that the church forbids it. I very much regret that you did not speak with her in my presence; you would have seen her love for me, and her genuine and reasonable attitude, not altogether clouded by passion (291).

The mother's judgment must have been premature, as she would tell the same person two years later that "Masha has completely changed since her [recent] decision to overcome herself, and she sees her happiness in carrying out the duties that religion prescribes to us" (298-99).

The effects of this long-lasting and unrequited love on Zhukovsky's life and poetry are well known, and we leave them out of the context of this study. ${ }^{127}$ However, Mariia's image as seen by the poet in love, as well as her response to his feelings, have a direct bearing on the norms and social values of the time, and it is this side of the famous love story that we consider here. From among the qualities that Zhukovsky believed, according to his above-cited diary, to have aroused his passion, Mariia's intelligence comes first and her sensibility follows. The ideal of an intelligent and sensitive wife, successfully promoted by sentimental literature of the late eighteenth century, became widely accepted by provincial society at the turn of the century. Notably, after having lived in the capitals and mingled in high society, Zhukovsky expressed a wish that his chosen one "not seek the diversions of the beau monde life"-a requirement enunciated by Bolotov half a century before in strikingly similar terms. To noblemen raised in the provinces, a baryshnia's propensity to avoid the attractions of the beau monde remained among the virtues befitting a future wife.

Raised in the spirit of Rousseau - an upbringing easily reconcilable, as mentioned before, with Russian tradition - both Mariia and Aleksandra deeply loved their mother and retained, throughout their lives, an unshakable faith in her. At fifteen Aleksandra wrote in her album: "Our mother inspired respect by her firmness, her virtues, and the tone of reason that she maintained in all her conduct. Our confidence in her was based on the conviction, which she had instilled in us, that she never did, and never requested that we do, anything for any purpose except our happiness." 28

In the same vein, but a decade later, a twenty seven-year-old Mariia writes to her cousin: "Duniasha, I have many, many things to tell you. The first and the most difficult: my mamen' $k a$ [mother] has left us for Petersburg. Can you imagine how hard and sad it was for me to part with her! I feel so much of an orphan that my heart can never relax" (255).

Both sisters' albums and letters are full of such passages, which suggest the old tradition of obedient reverence for elders and recall the lines devoted by Anna Labzina 
to her mother. Yet the new times brought along new expressions: half a century before, hardly any daughter would have addressed her mother as "Moi bestsennyi drug mamen'ka! Golubushka moia! [My invaluable friend mother! My sweet!]" (274) as Mariia did in 1822. Nevertheless, this sincere love and profound daughterly respect did not preclude Mariia from bitterly exclaiming: "I love my mother as much as it is only possible to love, but she has brought me many, many unhappy minutes!" (257). This is a reference to the role her mother had played in Mariia's relations with Zhukovsky and in the arrangement of her marriage.

Mariia's feelings reveal themselves in her numerous letters to Zhukovsky and to her cousins from Derpt (now Tartu), where she moved with her mother and sister Aleksandra after the latter's wedding in 1814. Unfortunately, many of these letters are not fully sincere, for Mariia's mother, as well as the other members of the family, inspected them $(137,140)$. This was a normal practice in many families, since correspondence was not considered a completely private matter. Mariia was at all times aware of the watchful eyes of her censors, yet her love and anguish show through.

The correspondence between Mariia and Zhukovsky is a long dialogue of two hearts that cannot be together. Mariia describes her little joys and sorrows; she calls him "my dear friend," "my angel," "my soul," "my good, incomparable Zhukovsky"; she admits tearing up some of her letters as she did not dare to send them (229). His answers fill her with delight and she ecstatically expresses her gratitude: "My good, sweet friend! I have just received your little letter. Ah, my Zhukovsky! how can I not be happy while you exist in this wonderful world! Just to think about you is equal to feel God's paradise. And everything here reminds me of you, in everything I find your angel soul .... my friend, my soul is full now, I feel such serenity and such comfort, as are too good for this world" (252-53).

Sometimes, notes of profound love sound in her letters: "[Y]ou cannot imagine how invaluable you are to me and how precious is my feeling for you" (219); "Whenever I feel sad without reason, I retire to my room and say aloud: 'Zhukovsky!' and it always gets better" (230); "You are in my heart, as you should be, both on weekdays and on holidays " (251); "Ah, my Zhukovsky! I [will] love you till the very death" (251). She recalls the time spent together with him in Muratovo as the happiest in her life. Only once did she have the opportunity to revisit the home where she had grown up and enjoyed life. She wrote to Zhukovsky from there: "I pray to God for the prolongation of this beautiful life, along whose course the lights of my guardian angelZhukovsky-line up! Who can be happier than I am? O my dear! your letter has restored everything to me! the past, and what is lost in the present, and all the charm of hope. ... I am happy now in Muratovo!... Your room, your letter in my hands, this is my earthly paradise!" (276).

Married in Derpt in 1817, Mariia died in childbirth six years later. Both her 
pregnancies, in 1820 and in 1823 , were extremely difficult, and both times she had a presentiment that she would not survive. In this mood on the eve of the deliverythere is no certainty as to which of the two-she addressed to Zhukovsky a letter that she intended to become her last farewell to the love of her life. Imbued with profound faith and humility, Mariia's deathbed letter is redolent of the lessons that had shaped her personality:

My friend! . It is to you that I owe the liveliest happiness I have ever felt! . . My angel! the only thought that worries me is that I have not been of sufficient benefit to this world, have not achieved the goal I was created for; but this excessive desire, which never left me in all my life- to accomplish something of benefit-shall not this desire be taken into account? . . . Now that I am addressing to you this letter from my tomb, I can also show you my heart as it is, without offending anybody. My friend! the attachment that I have for you . . . has adorned all my existence, without affecting the duties I had imposed on myself. To cherish you meant to cherish them. I loved my good husband as much as a person of his kindness and virtue can be loved, and I believe that I have made him happy, but it is you to whom were related each impulse of my feeling, each noble idea, each recollection -in one word, everything that related me to God, and I have certainly preserved this feeling up to this moment (28586).

Before concluding Mariia's story, it is appropriate to pay some attention to the language of her letters cited above. One is inclined to consider the many loving expressions in her texts as indicative of her fervent passion for Zhukovsky. But her letters to her female cousins, Avdot'ia in particular, contain an abundance of similar rhapsodies: "I love you with all the powers of my soul" (179); "[P]lease never stop loving me. ... I am confident in your love" (217); "Ah, my angel! . . you alone fill both my nightdreams and my day-dreams" (259). If these exalted declarations express Mariia's friendship, was her mother right about the nature of her feelings for Zhukovsky? Whatever the answer, we should be cautious not to sever emotions from the cultural context of the time.

Lotman has noted that Sentimentalism broadened the semantics of the verb "to love" by suppressing its erotic meaning, thus bringing about a new conception of the relationship between love and friendship. Once beyond the confines of the taboo region of sensuality, the word largely replaced other expressions for intimate feelings, and counted among the most frequently used words. ${ }^{129}$ Sentimentalism proclaimed ideal love to be based on friendship, which assumes the equality of both parties and emphasizes their personalities. As an outgrowth of friendship, love inherits this mutual respect and thus provides much-desired emotional comfort. Naturally enough, women became the most devoted proponents of the cult of friendship that spread in Russian society. Innumerable poetic variations of the "love and friendship" theme not only filled 
baryshni's albums but occupied their minds as well. ${ }^{130}$

The young Protasov sisters were by no means an exception. Aleksandra copied into her album a sentence by a German writer: "Love is a morning shadow which diminishes by every moment; friendship is an evening shadow which increases until the sun of life is extinct."' ${ }^{31}$ To judge by Mariia's letters, she largely shared this vision and seemed to value highly the friendship component in her relationship with Zhukovsky. While her language could be considered a tribute to contemporary cultural trends, the realities of her life proved the validity of the idea: a witness to Aleksandra's marriage to a man who made both sisters' lives miserable, she knew that respect, associated with friendship, could bring a woman much more happiness and security than love did.

In 1817 Mariia married I. F. Moier, their family doctor, a recent Derpt university graduate, and a Baltic German by origin. Her sister described her passive obedience in the following words: "She not only passed with humility under the yoke imposed on her by Providence, but also sought and found solace in it" (254). Mariia did not love her future husband, but it was her free choice to readily accept his proposal; also, by doing so, she could finally resolve her terrible situation in her sister's family, where everybody suffered under Aleksandra's violent husband.

Mariia had no illusions about Moier's disposition or refinement, but saw in his character the traits that she had been taught to value most: "His rule is to forget or never think of himself whenever other people's benefit is at stake, and to sacrifice everything to them. And these are not words but deeds" (156). She enthusiastically described his medical practice, his readiness to help the sick and the hungry, and so forth. Evidently, she was desperately trying to convince herself and her friends, Zhukovsky above all, that her future marriage "to the good Moier" was not a selfsacrifice:

One can safely entrust him with the happiness of a family, he has elevated feelings, and his soul is capable of appreciation and of fulfilling the duties imposed on him. I am sure that I shall preserve his confidence in me; his esteem and his friendship for Zhukovsky are as intense as they should be; I expect from him as much happiness as I crave and as it is possible to have. Dear friend! assure yourself that I would, myself, consider sacrifices as selfishness. Quiet life, sincere friendship, complete trust, and strong faith in that I depend upon an honorable, noble man-these are my future's foundations (172).

To the deeply religious Mariia, passion was not necessarily connected with marriage and family - the primary area of a woman's duties, which, if fulfilled, could cause her to hope for a better life after death. Typical of the time, these attitudes reveal the continuity of women's self-identification, as they seemingly differ little from those dating half a century back. There are, however, important dissimilarities: as Mariia's letters show, her conscientious adherence to what she deemed to be her duty was based 
largely on her own choice, and unlike her submissive and silent predecessors, she well knew how vast a distance separates one's dream from one's reality. While Zhukovsky had been and remained her dream, her marriage to Moier became her self-imposed reality. She wrote to Avdot'ia Kireevskaia a week after the wedding:

\begin{abstract}
My Duniasha, here I am-married. . . I shall frankly tell you that the moment when I convinced myself to give up everything related to my happiness, when I decided that I should no longer live for $\mathrm{Zh}$ [ukovsky] only, that anybody who asked for my hand would win it (for I decided to marry the first one who came along), this moment was terrible for me.... He [Moier] loves me as much as he is capable of loving, but my own experience has more than sufficiently taught me that it is not in my heart that I should seek pure and unalloyed happiness. ... My past happiness remains too vivid before my mind's eye, it adorns my present, because Zhuk[ovsky] is the angel of virtue and perfection; but I have to be worthy of him, and that is why a steady fulfillment of duty, without any notion of what used to be my delight, must fill my life and turn all my thoughts and recollections into a paradise (187-88).
\end{abstract}

This letter leaves no doubt about Mariia's feelings and hopes, which sad reality required that she relinquish. She helped her husband to take care of the sick, tended orphans, fed the hungry at a sheiter, avoided no domestic work -in a word, she tried to keep every promise she had given to God, to herself, and to those she loved and respected. ${ }^{132}$ She constantly developed intellectually, took lessons in science and arts, and read books. Yet her married life was dull and colorless, she had little in common with Moier, and her disillusionment grew. "This Livland has buried me alive for happiness," writes Mariia in a letter, but it is to Zhukovsky that she complains: "I have so little left to regret and to wish, that I live, literally, with my eyes closed. Only one thing dare I wish, peace as soon as possible! A useless life always seems too long. I am sorry if you do not like it - but you know how little good life is - this is not a groan but a prayer" $(220-1)$.

As taught by both her mother and Zhukovsky, Mariia Moier remained true to herself and firm in her faith through all her short life. Did reality turn darker than she had expected, or had her dream made it more bitter by contrast? It is difficult to tell; but, as her deathbed letter reveals, she certainly experienced her share of happiness, along with pain and distress, and died confident that she had lived up to her duties till the very end. And this, she believed, would count thereafter.

\title{
Aleksandra Voeikova, née Protasova
}

The story of the younger Protasov sister, Aleksandra (1795-1829), is another 
poignant example of a life gone awry in the grip of dependence on a malevolent man. She spent her childhood and youth in the intimacy of the Bunin family, where her loved ones-a caring mother, a kindhearted grandmother, an affectionate sister, and numerous cousins - created an atmosphere of harmony and confidence. As a young girl, Aleksandra inspired Zhukovsky to write his ballad "Svetlana," one of the best known in Russian poetry, so her relatives and friends often addressed her by this name. Beautiful and talented, tutored by one of the most creative minds of the time, she had every reason to expect much for herself. Life took, however, an unfavorable turn: she suffered a great deal and died, at the age of thirty five, far away from her family and friends. Yet she was known to have preserved, through the struggle and suffering of an absolutely terrible marriage, the cheerfulness and charming character that fascinated many a distinguished man.

Her future husband, A. F. Voeikov (1778 or 1779-1839), had been introduced to her by Zhukovsky himself, which contributed to the cordial welcome he received in the family and to the success of his proposal. The offer was reinforced by his ample resources - as many as two thousand serfs - which later turned out to be a figment of his imagination. Suspecting no prevarication and charmed by the suitor, Aleksandra's mother insisted that she accept. The baryshnia herself, who had hardly seen anything but the country, felt pleased and flattered by the attention of a rich, handsome man from Moscow, who was already known as a writer. Right after the wedding Voeikov and Aleksandra, accompanied by her mother and sister, left Muratovo for Derpt, where he served as a university professor. Very soon he revealed both his insolvency and his bad character. He humiliated and even assaulted his wife in full view of the community, insulted her mother and sister, and spent on himself both the money he earned and Aleksandra's dowry.

Aleksandra never blamed her husband and tried to hide her frustration from her relatives and friends. But they noticed everything and in turn made every unobtrusive attempt to help her. Zhukovsky used all his influence on Voeikov to stop his assaults. Mariia nurtured a plan to run away from home in order to force his attention to his wife's suffering and possibly arouse his compassion. Nothing helped. In his letters to Aleksandra, Zhukovsky preached submissiveness and humility: "In a woman nothing captivates more than subdued self-deprivation. Her virtues, her grace, her successes should turn into humility." 33 This advice by the highest moral authority in Aleksandra's life was by all means sincere, as her sister Mariia was getting similar recommendations from the same source, albeit to the utmost detriment of the advisor himself. Aleksandra and Mariia alike had no choice but to follow it.

Compelled to resign from the university in 1820 , Voeikov moved to St. Petersburg and embarked on a new career as editor of a literary magazine. Although he never stopped mistreating his wife, her life became a little easier. Assisting her husband 
in preparing works for publication, translating foreign poetry and prose, and even writing herself, Aleksandra found solace in friendship and social activity. Surrounded by men of letters, most of them Zhukovsky's friends, she soon turned her house into a literary salon and became its much admired and respected hostess. Young poets such as I. I. Kozlov, E. A. Baratynskii, and N. M. Iazykov submitted their poems to her attention and heeded her judgment. The more established writers, such as I. A. Krylov, N. I. Gnedich, N. M. Karamzin, K. N. Batiushkov, and P. A. Viazemskii, enjoyed the company of this beautiful and witty woman. Two prominent figures, A. I. Turgenev and V. A. Perovskii, were hopelessly in love with her. The members of the circle openly admitted that it was solely Aleksandra's charisma that held the salon together and kept them visiting, in spite of the husband's disgusting behavior.

Aleksandra's position as hostess of a literary salon was somewhat different from that of her aunt Varvara Iushkova thirty years earlier in Tula. As hostess and organizer, a woman had always been at the center of a salon; her role had now shifted, in many cases, to being the aesthetic focus of the gathering. Young men of the world commonly vied with each other in expressing their admiration for the hostesses of fashionable salons, extolling their merits and seeking their attention. Worshipped as goddesses, these "angels," "sylphs," "fairies" provided inspiration for poets' odes and composers' romances. Although the majority of them were, of course, young and beautiful, their admirers often regarded them not as human beings but as symbols of speculative values developed by literature and art. In this atmosphere of histrionics, the object of admiration was hardly supposed to have a life like everybody else - including her worshipers. Admiration could quickly turn into indifference, should everyday problems start showing through the glossy surface.

Aleksandra Voeikova enjoyed a worship that only the happy few had ever experienced. The best Russian poets exalted her during life and glorified her after death; wealthy and refined men fell desperately in love with her; and to many she was the ultimate embodiment of feminine grace. Yet all this could not alter her helpless and wretched position in her own family. Her husband proved to be unworthy not only of her love but, unlike Mariia's husband, of her respect either. Intellectually gifted and highly creative, she suffered from his eternal carping and petty faultfinding. Oppressed and humiliated in the very house where her admirers came to praise her, her only recourse was patience and faith. The expectations of her youth never materialized.

Aleksandra's closest friend, Aleksandr Turgenev, became one day incapable of further hiding his passionate love. Sharing with him many ideas and interests, grateful for his care for her and her children, she nevertheless closed her door on him immediately upon learning the nature of his feelings. Some friends considered this harsh treatment of the man, whose talents she appreciated and whose company she enjoyed, as proof of her own growing love which she deemed it her duty to suppress. Her style 
was resignation and self-sacrifice rather than what would later become known as the "Anna Karenina" type of behavior.

Suffering from a fatal disease, Aleksandra left Russia for the Mediterranean climate, never to return. Like her sister Mariia earlier, she never faltered in meeting her responsibilities and held fast to her beliefs. A bright individuality and a lofty mind distinguished this extraordinary woman, but the Domostroi code, blended now with new ideas, proved to be strong enough - even among the elite in the $1820 \mathrm{~s}$ - to fill her reality with pain and frustration.

\section{Avdot'ia Kireevskaia-Yelagina, née Iuskova}

Another provintsial'naia baryshnia of the Bunin family, Avdot'ia Iushkova (1789-1877), also grew up in the same emotional and intellectual ambiance of new trends mixed with tradition. She moved to Mishenskoe in 1797, after the death of her mother, Varvara Iushkova, and was raised by her grandmother, Mar'ia Grigor'evna Bunina. As distinct from her two cousins' bitter adulthood, Avdot'ia's life turned out more favorably in many respects, although she suffered bitter losses, eventually outliving her two husbands and all her children but one.

When Avdot'ia was fifteen, Vassily Kireevskii (1775?-1812) offered her his hand. ${ }^{134}$ Yielding to her grandmother's insistence, she accepted the proposal and, in a year, married the thirty-year-old man. She never regretted this decision. Her husband, although odd in a way, was a man of versatile intellect: he translated literary works and wrote original works of his own, and was a student of chemistry, medicine, and political science. An extremely devout and highly moral man, he strongly believed in the English civil law, and hated Voltaire, whose works he used to buy in order to burn them. In the spirit of the Enlightenment, he considered it his duty to provide guidance for his young wife in her education and reading. Probably due to his influence, Avdot'ia remained religious throughout her long life, a fact which did not prevent her from becoming a rather liberal political thinker.

The couple settled in Dolbino, Kireevskii's hereditary estate. The manor showed traces of a bygone sumptuousness. A huge house with interior marble décor was surrounded by beautiful gardens and a large number of outbuildings. Under Kireevskii's father, the house had been full of various barskie zatei (the magnate's amusements)buffoons, musicians, and storytellers; but in Avdot'ia's time only a devka-arapka (black girl) and a guslist (psalterist) remained. The guslist's duties included tuning the pianoforte and playing his psaltery during domestic concerts.

The lifestyle at Dolbino was deeply imbued with folk culture. Popular songs and ballads, sung and recited by numerous embroideresses, seamstresses, and lacemakers, permanently sounded in the house. No corporal punishment was ever administered to 
the serfs for any kind of misbehavior. On holidays the household serfs performed round dances, twined wreaths in the woods, and held boisterous festivities in the meadows. Many of them were literate and often read aloud to readily gathered listeners.

It is noteworthy that the moral views of Avdot'ia's husband differed conspicuously from those of her parents, and even more so of her grandparents, as he strongly disapproved of extramarital relationships. Once, when the governor visited Dolbino accompanied by a mistress, Kireevskii had the mistress's carriage driven away from the main entrance to the backyard - an unequivocal refusal to admit her to his house as an equal. This was a shocking affront to her patron, the most powerful official in the province. The humiliated governor had no choice but to move on, although he had planned to spend the night at Kireevskii's; he never dared to seek revenge on the offender. ${ }^{135}$

The behavior exhibited by Kireevskii on this particular occasion reveals a new trend in the overall moral attitudes of the time. Not more than a quarter of a century earlier, his own wife's grandfather overtly lived with a concubine, while her aunt's position as the namestnik's paramour met with the encouragement of both her parents and husband. The Voltairian concept of freedom, which many grandfathers in Russia had understood as a freedom from moral restrictions, was going out of fashion. In the eyes of the romantically minded grandsons, "everyday" adultery became part of the worldly routine that so bored them. As M. Lermontov later expressed this feeling in his "Duma" ("Meditation"):

Our fathers' daring sins make an insipid story.

Those sumptuous revelries, that studied childish lust! ${ }^{136}$

This change in attitudes in no way diminished the part that love and adultery played in the life of the nobility, but the woman's role in love affairs had altered considerably, especially in the capitals. Formerly, a woman, even if accepting a man's attentions, was expected to demonstrate no less submissiveness in this delicate matter than in any other. By contrast, the newer generation of young philanderers sought whirlwind romance and stormy passions as an antidote to the tedium of life. They found excitement in the freshly imported type of femme fatale-fickle, domineering, and choosing lovers, if any, according to her caprice. ${ }^{137}$ This phenomenon was, however, less noticeable in the provinces, where the image of a virtuous, family-oriented, but attractive and intelligent bride prevailed for both baryshni and their suitors. The third generation of the Bunin family had no children born out of wedlock.

As a married woman, Avdot'ia continued to spend much of her time with her grandmother in the propitious intellectual environment of Mishenskoe. Widowed in 
1812, she moved back there permanently. A relative of Bunina's, Prince I. M. Dolgorukii, left the following description of what he found in Mishenskoe in 1810:

\begin{abstract}
[Bunina] was over eighty years.... and two granddaughters of hers shared her time - the girls [sic] Iushkov [Avdot'ia and Anna], raised with much refinement, proficient in foreign languages, skillful at drawing and music. They like literature: they read whatever new is published. I found here a considerable book collection, and we most pleasantly spent the whole day together, forgetting that we were in the country. How to while away an autumn evening? ... Honestly, I never noticed it pass. Every minute we read various verses, discussed them as best we could, and expressed criticism or enthusiasm. ${ }^{138}$
\end{abstract}

An intimate friend to both Mariia and Aleksandra Protasov, Avdot'ia many times demonstrated her selfless readiness to help. She was an ardent supporter of the idea of marriage between Mariia and Zhukovsky and made every effort to persuade Mariia's mother to allow this union; as to its being considered a sin against religion, Avdot'ia offered herself as a sacrifice: she would expiate the sin by taking the veil and spending the rest of her life in a convent $(290,292)$. On learning of the sisters' difficult situation in Derpt, she hurried there despite a dangerous accident and subsequent illness. Zhukovsky later referred to these events: "To fall through ice 50 versts from home, to catch a severe cold, to live in an izba for two days, then to drive 200 versts in order to get only one day of rest and move on to cover another 1,000 versts, sick, your priceless life in danger, to sacrifice everything for this incomparable friendship-your friends, your children-only you can be such an angel-demon!" (164).

In 1817 Avdot' ia married A. A. Yelagin (1790-1846), a good, well-educated man who shared her interests and feelings. This time she chose herself a husband after her own heart. The Kireevskii-Yelagin family moved to Moscow in 1822 but preserved forever their connection with Dolbino and the entire locale. A famous literary salon formed in their Moscow house, frequented by A. S. Pushkin, A. Mickiewicz, P. Ia. Chaadaev, N. M. Iazykov, A. I. Herzen, N. P. Ogarev, A. I. Khomiakov, N. V. Gogol', and others. Avdot'ia Yelagina became its universally celebrated hostess and a source of inspiration to many. ${ }^{139} \mathrm{Her}$ existence acquired social significance and influence in the highest intellectual circles of Russian society.

Loved and respected by both her husbands and her numerous children (the famous Slavophiles Ivan and Peter Kireevskii among them), admired and esteemed by many prominent figures of her time, Avdot'ia had also to live through her share of pain and grief. Widowed at twenty three and again later, she saw several of her children die in infancy; six of her adult children died before her; and only one son lived to care for her in her old age. As early as 1817, after she married Yelagin, Zhukovsky wrote to her: "Up to now, you have been victim to every possible misfortune, and all kinds of miseries haunted you-now a new epoch will be likely to come, that of 
rewards and quiet happiness among your own family. This delight was impossible for you to have without a friend-protector" (25). This letter seems to refer not only to the bereavement of a young widow, but also to her straitened circumstances. The last sentence of the quotation deserves, in this respect, our special attention: the only hope for happiness coming to a woman is the prospect of a rich and caring husband. This good fortune fell to Avdot'ia's lot, thus providing the basis for her brilliant future.

\section{Anna Zontag, née Iushkova}

The life of Anna Iushkova (1786-1864), Avdot'ia's elder sister, provides another version of a young lady's destiny in the first half of the nineteenth century. As she later became a professional writer, her path cannot be considered typical, but it reveals the new horizons and opportunities available to her generation.

Anna inherited Mishenskoe from her grandmother and lived on the ancestral estate on her own. Prince Dolgorukii's diary contains a description of Anna's life in Mishenskoe before her marriage: "I was very cordially entertained at her place and spent a day there writing poetry and prose. Thus, I wrote a poem titled 'The valley of Mishenskoe' .... Iushkova is gifted with various talents, among other things she skillfully drew and, having painted a Madonna, gave it to me as a keepsake.... I have not lost the souvenir of the one who gave it to me out of friendship, and I always recollect the valley of Mishenskoe as a spot on the earth where I spent several hours pleasantly, lightheartedly, and freely."'140

A romantic, artistic person, Anna went through many disappointments in her life. She was her mother's least favorite child; as a baryshnia, she could not, for a long time, find any match. On becoming the lady of Mishenskoe, she was compelled to solve many difficult problems. Her cousin, Mariia Protasova, concerned with similar troubles, exclaimed: "How I regret our wasting so many hours in front of our musicstands and pianofortes! It would have been rather more useful to boil soap and mix paste."141 Thus, intellectual aspirations would collide with reality, which required that provintsial 'nye baryshni know how to "pickle cucumbers." Both Mariia and Anna, as well as many other provincial ladies, eventually proved to be capable of combining these skills. ${ }^{142}$

As the owner of Mishenskoe, Anna must have become a much better match, so two suitors offered her their hands in 1816, one of them a Muscovite and the other an American in the service in the Russian navy. Before making the final decision, she sought advice from Zhukovsky and got his encouragement to prefer the Russian:

I would certainly tell you a lot of nonsense about America in my reply, about Niagara, the Hurons, the Pennsylvania Quakers, and about the huge snake that swallows bulls and tigers but is, I believe, not to be found in America! . . 
From your last letter to your aunt, I gather that the reticent Moskva River with its turbid little sister Neglinnaia [river] have prevailed over Niagara! God bless dear Moscow! . . . And you ought to find happiness! You demand little from your fate; what you crave is so easy to make come true and is the best, too: good, active family life (88).

Of Zhukovsky's advice only the second part was acted on: in 1817 Anna married E. V. Zontag, the American, with whom she spent two happy decades. They passionately loved each other. Zontag proved to be not only kind and caring but also supportive of her active social position.

The Zontags traveled a great deal, and the variety of impressions absorbed by Anna contributed to her success in achieving her dream to become a writer. Her husband by no means dissuaded her from this endeavor but rather encouraged her to embark on a literary career. Her background was extensive, her acquaintance in literary circles was wide (through Zhukovsky and through Pushkin whom she knew while living in Odessa) and, as it turned out later, she had talent. Unlike her relative A. P. Bunina (1774-1829), who made her debut as a poet in 1806 and had to struggle with society's prejudice against women writers, Anna Zontag's first steps in literature twenty years later were relatively painless: although some prejudice still existed, society had largely recognized that women were also capable of literary work. ${ }^{143}$

Anna's husband supported her attempts and helped her with her translations. Her first published work - a translation of a novel by Sir Walter Scott-appeared in 1825; later she wrote several collections of didactic stories for children and became a prominent children's writer. An intricate plot, a somewhat sentimental touch, and an instructive ending distinguished her tales, plays, translations, and adaptations for both children and adults. Her Sviashchennaia istoriia dlia detei (Holy History for Children) enjoyed a long-lasting popularity, was published nine times, and awarded the Demidov prize.

In 1841, after her husband died and her daughter married a foreigner, Anna returned to Mishenskoe. The property was quickly falling into decay, so she lived there in deep poverty, her literary work remaining her only income. ${ }^{144}$ In 1849 , reflecting on her youth and comparing it to her present life, Anna Zontag wrote with a touch of bitterness:

Mishenskoe was different then from what it is now. At those times there was a huge house with outbuildings, winter flower gardens, greenhouses, fish nurseries, ponds; and though wooden, the building was maintained in order, for the property had not yet been divided up. All this has now disappeared. The building has rotted away; the ponds have burst the dams and receded; rushes have overgrown the fish nurseries. With what little means I have, I am not able to mend all this-and what for, for whom? I live totally alone, under a modest thatched roof, close to [the tombs of] my relatives, ready 
soon to join my loved ones. Mishenskoe is still beautiful because of its location, and to me it has twice as much charm because of the memories related to it. ${ }^{145}$

In severe financial difficulties herself, Anna spent her last money on such undertakings as supporting the school for peasants or renovating the local church (129-31, 139). Here is how she explains her actions on one such occasion: "I had this money amassed for the purpose of covering my little house with planks, for it sometimes happens that rain penetrates through the thatched roof; but now I shall stay with my modest roof. The church is more essential than the house, and I am not the only one who needs it" (139). A woman's self-sacrifice had long been among the patriarchal values, but the nineteenth century brought a new facet to it by extending its scope from the family to the social sphere. Similar processes transformed many other traditional values and concepts of the woman's world. It was to this trend that Anna Zontag largely owed her success as a writer and public figure. Notably enough, she herself perceived developments in this area by the middle of the century as excessive. By constantly pursuing emancipation, the new generation of Russian women was, in her eyes, ignoring its duties. She attributed this to the bad influence of liberal Western literature and freer family relations. She wrote to her friend:

It seems to me that there is too much selfishness nowadays among young men as well as young girls and women. ... The young generation of the fair sex, although by far more educated than their predecessors, have read too much into Georges Sand and her comrades and want to become emancipated. Generally speaking, there no longer exists any apparent respect for what we used to call duty and which we never dared to shirk. And all this is caused not by the spirit of our age as many believe, but by ourselves, the parents. We excessively nursed our children in infancy, we displayed too much joy at their successes, we belittled ourselves; so the children, seeing all this, became used to considering themselves important persons and their parents insignificant. I shall not be alive then, but the new, spoiled generation will bring up their children differently. Fathers and mothers will exert more influence on children, and there is hope that everything shall improve and they shall, finally, learn the importance of resigning oneself to legitimate power (133-34).

This statement indirectly reveals the far-reaching changes in domestic situations and family life by the mid-nineteenth century, in relation to daughters in particular. The phenomena described in this excerpt constituted what many contemporaries saw as "the crisis of the family." 146 Almost every generation complains about the destruction of the family, so Anna Zontag's criticisms could be interpreted as the grumbling of a peevish, elderly lady, but her ideas about raising children are strikingly close to a modern perception of family values. She calls for more balanced and better organized 
family relations; considers a certain degree of traditional respect for the elders as absolutely necessary; and believes parental overindulgence to be bad for children. As a professional children's writer, she was firmly convinced that it was not young girls' and women's emancipation as such, but the excesses of emancipation that society should reject. In this respect, her books and activities were consistently aimed at preserving what she deemed to be good in the age-old tradition.

Anna's life, though sad at the end, differed from the lives of the majority of her cousins and many other provintsial'nye baryshni. A happy marriage to a man who not only shared her feelings but also supported her intellectual interests and even her literary ambition was rather uncommon in the first half of the nineteenth century. Yet the very fact that she achieved such a marriage shows society's tendency toward more respect for women's endeavors, both in the private and public spheres.

Anna's success in literary work evidenced two important circumstances relating to women's social status. First, it proved that in the 1820 s society made a transition from the virtual rejection of women writers to the recognition of their right to take part, on equal terms with men, in the literary process. The second circumstance was no less important: the fact that a woman became a professional writer meant that society had basically accepted the idea of a noblewoman not only being economically independent from a man, but also earning her living by work. Along with many other facts, this was a manifestation of the gradual dissolution of the strict hierarchical structures within the depths of society, a process which began late in the eighteenth century and led eventually to the emergence of a new social group-the Russian intelligentsia.

\section{The Fourth Generation}

The fourth generation of women in the Bunin family provides an insight into the dream and reality of provintsial'nye baryshni in the second quarter of the nineteenth century. Some details of their lives are found in the unpublished memoirs of M. V. Beer ${ }^{147}$ Née Yelagina, a granddaughter to both Mariia Moier and Avdot'ia Yelagina, she dedicated her memoirs to her mother, Ekaterina Moier (1820-1890). The latter was in turn the daughter of Mariia Moier, née Protasova, Zhukovsky's flame. Ekaterina Moier was born and spent her childhood in Derpt. After her mother's death in 1823, she was raised by her grandmother Ekaterina Protasova. Her father, who served as rector of Derpt University, retired in 1836 and moved, with his daughter and motherin-law, into a newly purchased estate, Bunino, in Orel Province. Two cousins of Ekaterina Moier went to live there with them: Ekaterina (1815-1844) and Aieksandra (1817-1893), daughters to the then deceased Aleksandra Voeikova (Zhukovsky's "Svetlana"). The two Voeikov sisters came to the country after graduating from the Smol'nyi Institute in St. Petersburg. 
her room. Elena Ivanovna would keep a samovar ready, along with various country sweets: nuts, cranberries with honey, pastila [sort of marshmallow sticks], and so forth" (1. 6-6 ob.).

Trips to Chern' helped overcome the tedium in Bunino. A. A. Pleshcheev's son, Peter, nicknamed chevalier sans peur et sans reproche (1.7), owned the estate in the 1830 s. As witty, cheerful, and hospitable a character as his father, he had many children. Dances, performances, charades, and games never stopped in his house. Also, Avdot'ia Yelagina with her sons used to come in summer to the neighboring Petrishchevo where "life was in full swing" during their sojourns. They had a studfarm, so that the young girls and men could ride as much as they liked. A local landowner, Vladimirov, used to visit Bunino with his serf orchestra to stay for a week or more. Music then sounded in the house continuously. Ekaterina Moier's father, a brilliant musician and passionate music lover, could not afford his own orchestra; even a week of feeding the forty guest musicians, who consumed up to twenty samovars of tea daily, placed a burden on the household managed by Ekaterina. Her father enjoyed every moment of these musical periods, but the Voeikov girls felt nothing but ennui.

The family's daily life was simple. During the Yelagins' sojourns in the country, visitors to their relatively small house, sometimes numerous, slept on the floor. At the balls, frequent and not too formal, the young women appeared in dresses they sewed themselves from white calico- a sort of inexpensive cotton fabric. No less interested in fashion than their counterparts in the capitals, both young and elderly women in the country had much more freedom in choosing their own style (and much less money to pay for their clothes). Accordingly, fashion was but loosely followed in the country. As late as the mid-nineteenth century, one could still encounter provincial noblewomen wearing traditional Russian clothes. Thus, Ekaterina Protasova, widowed since 1805 but still a beautiful woman in the 1830s, had long ago put on an old woman's bonnet and a dark homespun shushun (Russian traditional loose overall). She dressed in this manner until her death in 1848, only substituting a white shushun for the dark one on holidays (ll. 14-14 ob., 22 ob.).

Soon the young female voices stopped ringing in the Moier house. Zhukovsky arranged the appointment of the Voeikov sisters as maids of honor at the Court, and they, happy as two queens, left the estate.

Ekaterina Moier stayed in the country. Beautiful and vivacious, she attracted many men's attentions and courtship, but turned down several offers. Zhukovsky and Avdot'ia Yelagina discussed her matrimonial future in their correspondence, as her late mother's will entitled them to do. A man by the name of Rzhevskii was expected to propose to Ekaterina, so Yelagina arranged to meet him in St. Petersburg. Zhukovsky advised her on this occasion: "You will be in Petersburg where Rzhevskii will possibly be; I recommend that you not continue any relations with him concerning this matter; 
let everything stay in statu quo. Do not make any further step without notifying Moier [the father]. She [Ekaterina] should not accept any offer without her own heart's consent, this is the first condition. But, were the heart to speak out on such an occasion, she should let it speak only with her father's consent" (68).

A young girl's "own heart's consent" is named in this rather businesslike letter as the first priority. The father's opinion ranks a close second. Very uncommon at the turn of the century, this type of marriage arrangement was becoming more and more acceptable. Now parents would often agree to bless a marriage even if they disliked or disapproved of their child's chosen mate. Avdot'ia Yelagina had an experience of this kind in her own family: her son Ivan Kireevskii loved a girl to whom he proposed. Yelagina did not approve of the choice and insisted that Ivan go to study abroad. Returning after five years, he immediately settled his marriage with the girl he was supposed to forget. This time the loving mother acceded and, not without tenderness and even some poetry, described the event to Zhukovsky: "The whole five-year-long tangle of misunderstandings, separation, common sense, etc., fell apart at one glance. On March 1, he saw her for the first time after five years of separation; surrounded by strangers, he gazed at her for two hours from a distance, and as soon as she moved to leave, an unknown power dragged him to follow her; he declared, right on the porch, his love to her, in one word, in one glance. The next morning he brought over a daughter for me to bless" (50).

Ekaterina Moier also chose herself a companion after her own heart. She refused Rzhevskii, and also N. I. Pirogov (later a famous surgeon). All the KireevskiiYelagin young men were in love with Katen'ka (as everybody called her), their second cousin, and selflessly renounced in each other's favor the right to marry her (11. 12-14 ob., 15, 16). Her future husband, Vasilii Yelagin (1818-1879), loved Ekaterina but, uncertain of himself and reluctant to hurt his brothers, did not dare to propose for a long time. She ended up revealing her own feelings, and thus their union was settled on the basis of their mutual love. The marriage took place in 1845 (1. $16 \mathrm{ob}$.).

Ekaterina continued to play an active role in her family after the wedding. She insisted that they live in Bunino. Her husband, a "man of wide reading," agreed, if only reluctantly - a hard decision on his part, for he had spent his youth in Moscow, disliked agriculture, and might soon have become professor of history at Moscow University (1. 18 ob.). Nevertheless, he sacrificed his career for his wife's sake-a rare and rather new phenomenon in family relations of the time.

By the middle of the century the large Bunin clan was on the wane. Since the 1770 s the family had belonged to the elite of provincial society. Yet wealth and influential connections were not the only factors behind this position; despite the family's vanishing affluence, its female members' intellectual potential increasingly contributed to its social standing. 
The Bunin family, with its abundance of surviving documents, provides a rare and happy opportunity for a historian to trace events in their interdependence and continuity. The stories of four generations of this family show that in several decades-a rather short historical period-more changes occurred in the status of Russian noblewomen, both within and beyond the family confines, than in several preceding centuries. The formerly patient, submissive creatures, fully dependent on father, husband or, sometimes, lover, largely gave way, by the mid-nineteenth century, to the fully developed personalities who often chose the way of life they preferred and played important social roles.

\section{"... all this is very ordinary"}

A specialist may learn a great deal from the examination of a collection of butterflies pinned to paper, but his knowledge is very different from that of a person who has watched them fluttering. Similarly, historians piece together evidence, which they deem to be relevant to a phenomenon of the past, and make certain generalizations, but it is useful to measure their conclusions against a contemporary's work in the same field, if available. The preceding sections of this study presented a number of individual lives that seem to add up to a rather diversified picture of how young provincial noblewomen lived in the first half of the nineteenth century. And yet, typical as these individual life stories appear from historical distance, each of them is unique in its own way. In order to ascertain that they provide sufficient grounds to extend our conclusions to other baryshni, this section presents a view on the same subject by a contemporary writer, who chose fiction as an impersonal means to summarize his empirical observations.

The more talented the writer, the better he or she grasps and conveys the general spirit of the time. Permeated with its creator's personal attitudes, a masterwork unfolds his or her individual vision. By contrast, a less talented author usually concentrates on the minor details of the phenomena under scrutiny in an attempt to draw a "truthful," or "real," picture. Ironically though not without reason, such pictures are often of greater interest to a historian than those created by true artists: while failing to produce a work of art, a mediocre writer sometimes succeeds in showing what his contemporaries consider as the banalities of life and, by moralizing upon matters of concern to them, presents the actual values of the time.

The novels Semeistvo Kholmskikh (The Kholmski Family, 1833) and Ol'ga (1840) by D. N. Begichev (1786-1855) are not literary masterpieces. Unsophisticated chronicles by a conservative observer of life around him, they nonetheless happen to be treasures for a historian. The author's lack of imagination, combined with the scrupulousness of a bureaucrat (Begichev ended up as a senator), have produced 
documents, rather than fiction. Because he had grown up in the country (on his father's estate in Tula Province) and then spent many years in service in the provinces (from 1830 to 1836 he was governor in Voronezh ${ }^{153}$ ), Begichev considered himself an expert on provincial life and, in his literary activities, explicitly endeavored both to expose unequivocally the provincial nobility's shortcomings and to indicate ways to rectify them. He defined his objectives in the following terms: "To present to contemporaries a picture of their way of life, delineating mores, misconceptions, prejudices, depravity, the mistreatment of inferiors, slander, the inequity of judges, and other improprieties." 154

Provincial life, as described by Begichev, looks different from what one finds in the Russian classics of the time. In Pushkin's "An Amateur Peasant Girl," the feelings of the young baryshnia and her sweetheart are of much greater interest to the witty narrator than their eventual compliance with customs and rules. Gogol's "The OldFashioned Landowners" is, in Svetlana Boym's words, "a tale of the writer's ironic nostalgia for the patriarchal way of life ... a kind of elegy to a world that is dying out." ${ }^{155}$ Both tales are full of poetry, the meticulously selected details of everyday life expressing the essence of the authors' personal vision. Along with Pushkin, the reader is excited about the reunion of the young lovers or, along with Gogol, feels a nostalgic compassion for his simple-minded characters. No conclusions to be drawn from the reading are preordained, the inner logic of the text leads to them by the law of harmony.

As for Begichev, poetry is a stranger to him. His works are filled with minute details that must have bored his contemporaries, who, as distinct from a modern researcher, were perfectly able to provide the links missing in concise descriptions by more skillful novelists. But the reason for the disparity between Begichev and his great fellow writers is not so much the magnitude of talent as the perception of life values. While Pushkin and Gogol admiringly reproduce the beauty of what they see and feel, Begichev is busy with commending the "good" and castigating the "bad" in order to edify and instruct society. "[A]ll this is very ordinary, and I have definitely no right to call my book a novel," says Begichev in the preface to Semeistvo Kholmskikh (1: xxiv), and this statement, even if meant as a literary device quite common in fiction, is probably truer than the author intended it to be. As he never even tried to disguise his protagonists, people often recognized themselves in his characters.

One concludes from the preface that the author targets all kinds of public vice (including, presumably, lax morals) that he blames on the increasing influence of Westem ideas. His tone is primarily ironic, but this irony is selective, aiming not so much at the old order as at the infatuation for the new one. A reasonable combination of ageold values with limited and carefully chosen elements of the new lifestyle, especially in regard to young unmarried daughters, appealed to Begichev and many other provincials. 
In contrast to the Bunin girls' letters and diaries, which express baryshni's dreams and feelings, the Begichev chronicles show life "as it should be," according to an elderly male conservative, and reveal the average moral and behavioral model of the time. Nevertheless, the aspirations of his literary heroines and those of the real young ladies are largely alike, and even more so their realities.

Semeistvo Kholmskikh presents an entire gallery of provintsial'nye baryshni's portraits. The scene is set in a province in the steppes, in the 1820s and 1830s. All the characters, including the baryshni, are ordinary people without any romance about them. Marriages are arranged in the "good old" traditional way, tried and tested by previous generations. Begichev shows his complete approval for his protagonists' "correct" behavior and his conspicuous censure for all who act otherwise, when he describes a young man who is deeply in love:

[He] does not try to divert the girl, very much attracted to him, from the path of virtue, does not persuade her to forget all decency, elope with him, flee from her parental house to a far-away region, anywhere, and so forth. My hero is so feeble as to follow the cold advice of an old woman, keep away for a while in order to test himself: is he really thus passionately in love? My heroine is frigid like nothing on earth. Her foible, too, is to heed reason and Religion, while harboring a feeling of passionate love. Not even once did she develop a fever; sadness and despair never consumed her sensible heart; she did not grow emaciated or turn yellow; nobody noticed any sweet pensiveness in her eyes; in one word, she revealed no extraordinary indications of passion. She kept her health, her freshness, a clear complexion, continued to perform her duties, remained an obedient daughter and a good relative. And what concluded all this? My lovers, like commoners, conjoined in legal matrimony and settled down in the country! (1: xxii-xxiii).

Here a happy ending is eventually achieved through following the rule of contraries: the young man's wise and prudent behavior contrasts with what he could have done, had he followed the new-fangled fashion; the girl avoids poverty, loss of decency and health, and other disastrous consequences. All the potential misfortunes are described in such detail as to suggest that they are no figments of the author's imagination but commonly occur in real life. In his usual self-opinionated manner, Begichev refuses to analyze any subtleties that might exist beyond the confines of what he deems to be correct actions. Paradoxically, this down-to-earth pattern, both in its positive and negative aspects, applies to the fate of Mariia Protasova, who, on the one hand, lived up to her duties (coincidentally, she even married a commoner) and, on the other hand, suffered intensely from the consequences of her passion.

Virtually all the female characters in the novel, both barysinn $i$ and their mothers, are concerned about finding a good match. The means to achieve this goal are among the newly adopted: a mother suggests at a formal party that her daughter loosen the 
shawl around her shoulders; the young ladies play the pianoforte (one of the mothers arranging that a potential suitor, known for his love for music, should not notice her daughter's lack of skill); they give performances, recite French poetry, dance fashionable dances-each one "better than the other" $(1: 6,10-11)$. The author's irony notwithstanding, these festivities of the steppe nobility look quite civilized; as for the host, who understands not a word of the French poems, he makes up for this deficiency with splendid fireworks and illuminations. The author finds the behavior of both the girls and their mothers somewhat unnatural, but on this occasion his irony is rather good-humored, for they do not transgress, to his mind, the line of the acceptable.

The very definition of what Begichev considers acceptable, or decent, represents the overall attitudes of the time. The following passage reveals a new trend in matrimonial arrangements on a baryshnia's behalf-the recognized importance of balancing material considerations with the girl's feelings:

\begin{abstract}
Kholmskaia got married at a young age. Left an orphan, without any guidance for choosing a spouse, she did not listen to the voice of reason. Of course, wealth alone cannot constitute real well-being; however, everything has limits. To obey, as one tends to do when young, nothing but one's heart's impulses, never to think of the future and to consider the man, whom an ingenuous girl chooses for a spouse, to be the model of perfection-all this must be leading to the same consequences as the other extremity, when only wealth is taken into consideration - an inevitably unhappy life for both spouses $(1: 21)$.
\end{abstract}

If things are arranged "the right way," however, a girl heeds her parents' guidance and is not allowed to act independently in this matter. Having gone through the pain of a needy marriage, Kholmskaia does her best to spare her four daughters this lot. A rich prince proposes to one of her daughters, and the mother, in her attempt to arrange this marriage, instructs the would-be bride in the following manner:

"One should disregard some of [the husband's] shortcomings if they do not
result from bad morals. There exist no perfect people on earth, and Prince
Ramirskii, having apparently reached the age of almost forty years, is not
notorious for any of the vices the rich usually indulge in. For this alone he is
worthy of my respect."
"He is very kind", [the daughter replied,] "condescending, and seems to be of
a most pleasant and peaceful disposition. His affluence without these qualities
could never have attracted me."
"As to this circumstance", [the mother continued,] "trust me that neither you
nor any other betrothed can find out for sure what their fiancés disposition is.
A girl does not even know her own qualities until she is married. For example,
she is totally unaware of jealousy, this bad vice that can have the most fateful
consequences in marniage. The betrothed couple could spend ten years together
and never manage to know each other's characters. In a drawing-room, observed
by many, in mutual attempts to please, both he and she are continuously on 
guard and never let each other notice anything. A man is even more opaque than a girl: he knows that marriage gives him all the power; he temporarily endures everything he does not like in his fiancée, for he has the right to later rearrange everything according to his taste. However, what I am telling you now by no means applies to Prince Ramirskii. I rather concur with you that his disposition is genial and good; I am certain, at least, that you will avoid a considerable inconvenience that often causes annoyance: you will not be obligated to ask him to pay for any tiny expense of yours. This might seem nonsense but, having modest means, one cannot avoid it and this petty thing can often cause great misunderstandings between the spouses" (1: 32-34).

This flow of worldly wisdom gives us a thorough notion about both premarital and marital relations "as they should be." Material issues, in the foreground as usual, are provided a psychological basis; the future spouse's character is considered an important factor as well. The unconditional recognition of the man's traditional right to shape his wife's attitudes and demand that his will be fulfilled combines with a new understanding of the family climate, the wife's limited financial independence contributing to the well-being of the family. This conversation sounds like one that could have occurred between Aleksandra Protasova and her mother upon Voeikov's proposal. If only real life were patterned after this "wise" scheme by Begichev! In Aleksandra's case both the groom's disposition as well as his means proved to be inadequate, and she had not the luxury of any, even limited, financial independence, which could have been of great help to her.

Begichev didactically sets forth situations that can occur if, instead of obeying the rules of "correct" demeanor, girls select models from improper sources, foreign novels being the most dangerous. Like the young Bunin girls in real life, his fictional provintsial'nye baryshni are thoroughly conversant with European literature, which shapes their dreams of marriage in the spirit of contemporary fashion. Kholmskaia's second daughter makes her choice according to the sentimental novels she has read and enjoyed: "It never occurred to her to even think of Aglaev's means: his love, a small hut, brown bread, spring water - that was all she thought was needed for a good life!" (1:43). Although reality turns out to be close to this dream, it loses all its appeal once it has come true. Her husband, poor as he is, spends what little he has on various sentimental projects (pavilions and flowerbeds around a shrine of Hymen) and totally ruins the estate; the wife is sick, pale, and has little to eat except bread (5: 32-35). The novelist's message is easy to decipher: a life ought to be based upon fundamental realities rather than on dreams inspired by fiction.

Another issue Begichev amplifies through his novel is society's new requirements of a nevesta. One of Begichev's characters, a Petersburg woman of the world, puts her adopted son's fiancée to a rather demanding test: 
Pronskaia continued her moral tests and examinations of Sof'ia. She was already assured of her extraordinary intelligence, patience, benevolence, strength of character. During this period, she also saw that Sof'ia had received a good education: in addition to being such an outstanding expert in needlework, she read much and was knowledgeable about domestic and foreign literature. The best authors, Russian, French, English, and Italian, were known to her; she reasoned about them soundly and thoroughly. Pronskaia also made sure that Sof 'ia was not too much attracted to the pleasures of high life yet did not reject them altogether. Now she only wanted to find out whether she had a taste and knowledge of the fine arts (4: 187-89).

Begichev provides us here with a rather complete list of qualities demanded of a good young female. The first consideration is the girl's character, as it was in Bolotov's time and will, probably, always be. However, the outdated "obedience" finds a substitute in the more civilized "patience," accompanied by new qualities such as intelligence, benevolence, and strength of character, the latter trait hardly connoting any obedience at all. While household skills remain among the traditional requirements, the new ones include not only the girl's proficiency in languages, Russian and European literature, and even the fine arts, but also her ability to voice her own opinion. The fact that a conservative observer approves of all these qualities in a model baryshnia of the 1830 s reveals the great distance that society's attitudes toward women had covered in only half a century. Foreign literature in this list does not conflict with Begichev's beliefs: as a moderate thinker, he claims to respect progress and wishes only to make it more manageable; he deems it his duty to tell girls about the dangers they face and provide them with "correct" examples.

To be precise, the above set of requirements are established in the Begichev novel by a St. Petersburg woman of the world and better befit a girl from the capital. Were a similar list to be compiled in the provinces, it would probably set a less high standard for education. It is, however, noteworthy that a girl from the provinces successfully passes the test and proves that a provintsialka (female provincial) is not inferior to any girl in the capital, if she is committed to the correct values and follows sage advice. Once again, the "ideal" fictional heroine has prototypes in real life, as this description by Begichev is largely applicable to the Bunin baryshni, who would easily have met all of these criteria.

There is one more entry in the list of values required of an ideal nevesta-her attitude toward "the pleasures of high life." Bolotov withdrew from offering his hand to his first flame because of her attachment to them; Zhukovsky praised his beloved Mariia for having no such inclinations; now Begichev puts a similar requirement in the mouth of a character who belongs to the beau monde of the capital. Reflecting both his own and society's views about the role of a young woman in the public sphere, this attitude proves that, even in the capitals, high life was associated with a freer and more 
liberal lifestyle. As distinct from earlier times, however, Begichev's ideal nevesta should "not reject them [high life pleasures] altogether"--a tribute to progress and to his own rank in official St. Petersburg. In the provinces, the prejudice against the distractions of the beau monde, linked in the public eye with looser morals, had more adherents and had changed little in a century.

Begichev elaborates in his other novel, $O l^{\prime} g a$, on the consequences of a baryshnia's fascination with high life. ${ }^{156} \mathrm{Ol}$ 'ga, a sensible, provincial noble girl raised in the Smol'nyi Institute, comes to Moscow and, under the influence of her frivolous aunt, falls for a libertine, "an impudent Voltairian." To her aunt, who embodies the Moscow beau monde's views, neither the suitor's moral qualities nor his financial situation matter so long as he is young, "an interesting Guards officer," and a brilliant dancer. Ol'ga dreams of marrying the young man, who turns out to be interested in nothing but her dowry. At this point, however, the patriarchal attitudes of Ol'ga's provincial parents come onto the stage. The rich and influential father takes offense at the proposal by a poor nobleman from an obscure family; the old-fashioned mother is appalled by her daughter's adherence to novels and the wooer's attempts to defy the proprieties. The young man's parents, poor provincial noblepeople, share this opinion. Bewildered and pining from despair, Ol'ga develops a disease that drives her to the verge of death. Fortunately, her narechennyi (betrothed), long chosen by the parents to marry her, steps forward: he saves her life and displays his exalted soul by not compelling the girl, in love with another man, to stand by her parents' promises. He exposes the crafty schemes devised by the "Voltairian"; his life-giving homilies, nobleness, and righteousness heal the innocent victim of the high world's vices; and finally, the "correct" provincial values triumph when the young couple join in matrimony.

We are presented here with a sentimental pattern of female behavior not uncommon by that time both in literature and in life. The young girl imagines herself the heroine of a French novel; her own feelings and her judgment about other people's opinions are almost exclusively based on literary quotations and allusions (1:203, $218,2: 155$, etc.). Begichev contrasts real life to the formulas borrowed from literature and strongly condemns the latter for bringing about false values that tempt young, ingenuous minds. Describing the symptoms of Ol'ga's illness in terms almost identical to those used earlier in Semeistvo Kholmskikh to denote what his other heroine managed to avoid, he underlines how real a danger these temptations represent.

Ol'ga's two suitors exemplify two opposite models of male behavior: while the insidious dandy, fickle and conceited, combines in his character all possible vices, the righteous and magnanimous provincial gentleman embodies all possible virtucs. To Begichev, the former is an outcome of pernicious Western influences, including the inevitable Voltairianism; whereas the latter's many excellences result from following 
the old good tradition without prejudice to his civilized education and refinement. Ol'ga's confusion, disappointment, despair, and eventual insight lead her to the realization that her dream was wrong and that, by doing nothing more than complying with her parents' will, she would have found her real happiness. It is noteworthy that, instead of simply exercising his right to marry the girl, her betrothed, who represents the "right" model of behavior, releases his predestined bride from her pledge and earns her affection by his personal qualities. Such respect for a girl's feelings was unheard-of in Bolotov's times, but became quite conceivable in the 1840s (for instance, Ekaterina Moier's husband, Yelagin, sacrificed his career for her sake).

\section{Readings for "a girl's innocent soul"}

Begichev's intense focus on the far-reaching influence of literature on young girls' minds and hearts is not off the mark. No matter how much he exaggerated the harm it could bring, the majority of his contemporaries shared the idea that reading was inseparable from the image of a baryshnia. While their male counterparts were provided with a formal education in a military institution or university and could choose a career for themselves, young noblewomen usually spent their girlhood at home or in a boarding-school, and their environment changed little after marriage. Living in the relative isolation of the country, subject to rather demanding restrictions on their conduct and acquaintance, many baryshni had no source of information about the outside world except books, which largely shaped their personalities.

Girls' preoccupation with reading left its imprint on the Russian language. The English expression "blue stocking" has its direct translation in Russian, sinii chulok, which refers to old maids, aged baryshni who never married. This idiom reflects the fact that contemporaries considered the original meaning of the expression-learnedness-as typical of baryshni. (Paradoxically, it no longer connotes any intellectual inclinations.) "She wanted to be no worse than other baryshni; she rushed to read books," thus the protagonist of Turgenev's "Asia" speaks of his young sister, adding, quite in the spirit of Begichev, "what good could have come out of it?" 157 Reading habits became especially widespread in the first half of the nineteenth century when women's social roles in real life were often patterned after the literature they read. The prominent hostesses of the nineteenth-century literary salons provide a classic example of this phenomenon. ${ }^{158}$

Nevertheless, Begichev had numerous allies who denounced literature as an essential cause of "the corruption of morals in Russia" and one of the imminent dangers to young girls, who were drawn to pernicious novels instead of enjoying "highly moral [books] ... suitable to [their] age." (Ol'ga, 2: 179). Whereas in the 1760s and 1770s Anna Labzina's patriarchal mother absolutely denied her permission to read fiction, 
the more civilized moralists of later times acknowledged the benefits of reading, but insisted on unrelenting parental guidance. This reminds us of Bolotov with his discriminating approach to the selection of "correct" books for instructing "a girl's innocent soul," and of Anna Zontag with her invectives against George Sand, who allegedly helped bring up a generation of young people oblivious to their duties.

Reading made provintsial'nye baryshni special in Pushkin's eyes, as is implied by the passage from "An Amateur Peasant Girl" quoted above (p.10). His attitude toward novels appears quite dissimilar from Begichev's: Begichev sees a lack of real life experience and, as a consequence, the attraction to fashionable novels in the capitals; in contrast, Pushkin argues that provintsial'nye baryshni seek knowledge of life in novels, as their reality is much more monotonous than that of their disillusioned counterparts in the capitals. Where Pushkin finds an elevating influence on young souls, Begichev sees the destructive impact of fashionable Western ideas. This controversy not only results from the divergence of the two writers' world outlooks, but also draws on their different personal experiences in the two universes, the provinces and the capitals. However, both men would probably have agreed that books for young girls should be good and beneficial to their hearts.

With practically no books for youth and children available in the eighteenth century and very few of them in the first half of the nineteenth, parents met serious difficulties in selecting reading material for their daughters. There existed serious lists of "readings for girls." In N. Emin's novel Rose (1786), the protagonist knowingly discusses literary matters with particular regard to female readers:

It seems to me that Fielding's novels, Sophia and Emile, new Abelard, Marmontel's tales, works by Mme. Riccoboni, Mlle. Sternheim, as well as Wieland's works, will reward a beauty in tedium, without harming her soft heart or suppressing her spiritual qualities; truth is embellished in these books, vices laid bare in their ugliness, examples taken from nature; many ... tend to omit the moral admonition and are only fascinated with the magic plot of a novel that excites them. For those, I believe, their tutors should choose such tales as not to ignite their imagination; however, those beauties who seek some food for thought, those beauties who symbolize virtue and sweetness, if I am not mistaken: Young, Werther, Grandison are their consolation. ${ }^{159}$

Thus, the following authors were considered decent with regard to girls' reading: Henry Fielding, Jean-Jacques Rousseau, Jean François Mamontel, Marie Jeanne de Mazière Riccoboni, M. S. Laroche, Christoff Martin Wieland, Edward Young, Johann Wolfgang Goethe, and Samuel Richardson.

Yet the market was flooded with cheap novels of poor quality, some of which were quite capable of truly corrupting an innocent girl's mind. ${ }^{160}$ In a rather significantly titled work, A Pocket-book for Old Men and Women, Unmarried Ladies and Bachelor Men, Young and Aging Girls, Dandies, Giddy Boys, Ladies' Men, Gam- 
blers, etc., Coming to Moscow, or Allegorical Advice to Them (Moscow, 1791), satirist N. Strakhov warned parents against buying books about virtue for their children, "for all tales treating this subject are nowadays considered similar to A Thousand and One Nights." In order to keep pace with the time and conform to the latest requirements of fashion, he sarcastically insists that wise parents, of daughters in particular, should choose as their children's "guide to good conduct and virtue ... various songs and depraved works by foreign scribblers." 161

Some of the specimens in the reading repertoire of the gallant century helped, indeed, to suggest that adultery was an acceptable style of behavior. The "best-seller" of the 1760s and 1770s, the rather risqué A Thousand and One Nights, as well as its numerous renditions and imitations, enjoyed wide popularity among Russian readers. ${ }^{162}$ Significantly enough, Igor Kon, when enumerating sexually explicit texts available in the first half of the nineteenth century, refers exclusively to those created in the second half of the eighteenth century: "Young gentlemen of Pushkin's time could enjoy not only Denis Diderot's Immodest Treasures and the writings of the French 'libertines' but also the bawdy verses of Ivan Barkov, famous as Russia's first erotic poet."'163 Although it was highly uncommon for girls to get hold of this kind of literature, one can understand those who were worried about its circulation and potential damage to the young.

Concerned about the scarcity of literature for children in the 1820 s, Anna Zontag became one of the first Russian writers to work in this field. It is interesting that Zhukovsky suggested to her and to Avdot'ia Yelagina that they translate some of the best works of world literature, A Thousand and One Nights among them. Although the project failed, it is known to have excited Yelagina who discussed with Zhukovsky from which language, French, German, or English, to render the Arabic tales and expressed her concern as to "what the orientalists would say." 164 Along with novels and tales for the project, Yelagina planned to include in the selection some didactic works for mothers. ${ }^{165}$

As in the matter of girls' education, the responsibility for choosing the right books for them usually lay with their fathers or elder brothers. The poet, writer, educator, and future adviser to Alexander I, M. N. Murav'ev (1757-1807), wrote, while serving in Moscow and St. Petersburg in 1777-1778, a large number of letters to his younger sister, Fedos'ia (1760?-1792?), who lived with their father in Tver'. ${ }^{166}$ The brother's letters reveal his tender feelings for his sister and his efforts to help develop her mind and soul. The sentimental cult of friendship permeates Murav'ev's references to both their favorite novels and their reciprocal feelings. He writes: "You like Wieland: don't you accept his favorite ideas that there exist souls mutually akin and delighted to contemplate each other?... You will, undoubtedly, read my letter as one to a kindred soul" (360). 
Murav'ev fails to provide his sister with an appropriate program for education, but tries to compensate for it by discussing the novels he read and plays he saw. He advises his sister to read Horace, Socrates, Boileau, Corneille, Montesquieu, Goethe, Marmontel, Rousseau, Sumarokov, Voltaire's early works, and so on, and buys and sends books to her. He insists on her rereading some authors, particularly Montesquieu, encourages her to analyze them and describe her opinion to him. As to Voltaire, Murav'ev tries to protect his sister from a superfluous interest for mon cher vieillard, as he calls the writer (359), and offers her his explanations and critique of his works. In order to extend Fedos' ia's education beyond literature and languages, he intends to send her L. Euler's Lettres à une princesse d'Allemagne sur divers sujets de physique et de philosophie "as one of the best courses in physics for a lady" (300). The real value of books for both of them is revealed in one of Murav'ev's exclamations: "You are, indeed, as wonderful as a book" (309).

A family chronicle by E. I. Raevskaia, a noblewoman from Tula Province, describes, among other figures, the author's mother who, as a young girl in the $1800 \mathrm{~s}$, got the derisive nickname of Volter for being an avid reader of historical and philosophical works as well as many novels for adults. Referring to her own childhood, Raevskaia brings up the following details:

\begin{abstract}
Strictly speaking, no children's books existed back then in the twenties, not only in Russian but also in French. ... We were not allowed to read fairy tales; our mother deemed them to be dangerous food for thought. ... As to Russian books for children, they simply did not exist at that time. So I was compelled, at the age of ten, to sit for hours somewhere in a corner swallowing from cover to cover Racine's, Corneille's, and Voltaire's tragedies, and those of Molière's comedies I was permitted to read. In those too, however, I used to come across some expressions not meant for children and even far from decent. I approached my mother to have her explain the words I did not comprehend and my questions probably embarrassed her very much. ${ }^{167}$
\end{abstract}

With the rapid growth of the book trade and public libraries, established in the 1830s almost in all provinces, provintsial'nye baryshni gained easier access to books and magazines, both Russian and European, and did not considerably differ in this respect from their counterparts in the capitals. Intellectual occupations in the provinces were becoming very much the norm. While a master's study became relatively common in the 1780 s, "art rooms" and separate studies for women started to emerge in the first half of the nineteenth century. Avdot' ia Yelagina had a study in her country house, as well as a special room for manuscripts, a library, and a ronm for heaux arts where she kept books, rare engravings, art albums, a collection of pictures, and a pianoforte. Her book collection was so huge that bookcases were located in nearly every room. ${ }^{168}$ 
The number of people in the provinces who devoted themselves to creative work and cultural activities kept growing. For example, more than two hundred people writing fiction and scholarly works, memoirs, and music lived in Tula Province from the late eighteenth century through $1850 .{ }^{169}$ The works they created were disparate in their quality and mostly amateurish. However, these authors lived in the neighborhood and mingled in local society; many examples tell us that knowledge and creativity could sometimes be as important as wealth and connections.

This educated stratum of the Russian provincial noble class provided a solid basis for "high" literature and art. In the first place, they largely determined the environment in which the younger generation grew up, including our heroines. Provintsial'nye baryshni were the main audiences for writers and composers. As one of Pushkin's heroines notes, expressing the author's opinion, "now I understand why V[iazemskii] and P[ushkin] like small town baryshni so much. They are their true public." ${ }^{170}$ Receptive and responsive, they eventually became one of the essential factors in driving the entire country's cultural progress.

\section{Conclusion}

At the beginning of this essay, I mentioned the common stereotype of a provintsial'naia baryshnia, formed long ago in the capitals and alive even now. It used to have some basis in fact but, like any other stereotype, did not convey the complexity and the dynamics of the real phenomenon. Its negative component appears to be a rather natural manifestation of the krasnyi ugol view of everything outside the center of the country. The sometimes condescending attitudes of the capitals encountered a wary and lukewarm response in the provinces. Ideas, norms, and manners, considered correct and valuable in the capitals, did not easily find their way to the provinces. N. S. Leskov expressed this, with his usual irony: "[T] the walls of the house, another life was rolling on and ringing out, new, weaned from the home traditions: other people, at whom the country was still looking like a bewildered hen looks at the ducklings she has hatched."171

The provinces nevertheless absorbed the new elements and changed continuously, if gradually. And nobody was supposed to live up to society's mutable expectations more than baryshni in their constant effort to keep pace in the highly competitive Vanity Fair. Throughout the entire period from the mid-eighteenth to mid-nineteenth centuries, education and literature increasingly influenced young ladies' conceptions and interests as well as their daily life. Although life required, as it always had, that a provintsial'naia baryshnia should be a skillful and industrious mistress of the house, the stress was largely transferred to the sphere of ideas and sensibilities. The time came for turgenevskie devushki (girls described in Turgenev's works) to enter the 
scene.

With the turn of public consciousness toward personality and individual values, the dream and reality of provintsial'nye baryshni achieved more harmony. Privacy in their lives acquired a new meaning, allowing them to dedicate themselves more often to pursuing their happiness and personal needs. At the same time, the developments in public life created new opportunities for the baryshni, who, due to their education, talents, and charm, played a very considerable role in society. 


\section{Notes}

1. The Prose Tales of Alexander Pushkin, trans. T. Keane (Freeport, N.Y., 1971), 307. Further translations are mine, unless otherwise indicated.

2. For more details see D. Greene, "Gender and Genre in Pavlova's A Double Life," Slavic Review 54, 3 (Fall 1995): 563-77.

3. M. Foucault, Histoire de la sexualité (Paris, 1976); J. T. Costlow, S. Sandler, and J. Vowles, eds., Sexuality and the Body in Russian Culture (Stanford, Calif., 1993), 2.

4. P. Quennell, ed., Affairs of the Mind: The Salon in Europe and America from the Eighteenth to the Twentieth Century (Washington, D.C., 1980); D. Goodman, The Republic of Letters: A Cultural History of the French Enlightenment (Ithaca, N.Y.: 1994); J. Habermas, The Structural Transformation of the Public Sphere: An Inquiry into a Category of Bourgeois Society, trans. Th. Burger (Cambridge, 1989).

5. Quoted in O. Bernier, The Eighteenth-Century Woman (New York, 1981), 7.

6. For more information see N. Pushkareva, Women in Russian History: from the Tenth to the Twentieth Century, ed. and trans. E. Levin (Armonk, N.Y., 1997).

7. Iu. Lotman, Besedy o russkoi kul'ture. Byt $i$ traditsii russkogo dvorianstva (XVIIInachalo XIX veka) (St. Petersburg, 1994), 58.

8. On the evolution of social ideals, see M. Raeff, Origins of the Russian Intelligentsia: The Eighteenth-Century Nobility (New York, 1966), and "The Russian Nobility in the Eighteenth and Nineteenth Centuries: Trends and Comparisons," in The Nobility in Russia and Eastern Europe, ed. I. Banac and P. Bushkovich (New Haven, Conn., 1983), 99-121; C. S. Leonard, Reform and Regicide: The Reign of Peter III of Russia (Bloomington, Ind., 1993); W. Gleason, Moral Idealists, Bureaucracy, and Catherine the Great (New Brunswick, N.J., 1981); W. R. Augustine, "Notes Toward a Portrait of the Eighteenth-Century Russian Nobility," Canadian Slavic Studies 4, 3 (Fall 1970): 373-425; J. L. Black, Citizens for the Fatherland: Education, Educators, and Pedagogical Ideals in Eighteenth-Century Russia (New York, 1979).

On the status of women, see H. Goscilo and B. Holmgren, eds., Russia, Wornen, Culture (Bloomington, Ind., 1996); R. Marsh, ed., Women in Russia and Ukraine (Cambridge, 1996); B. E. Clements, B. A. Engel, Ch. D. Worobec, eds., Russia's Women: Accommodation, Resistance, Transformation (Berkeley and Los Angeles, 1991); D. Atkinson, A. Dallin, and G. Warshofsky Lapidus, eds., Women in Russia (Stanford, Calif., 1977); B. Farnsworth and L. Viola, eds., Russian Peasant Women (New York, 1992); B. Heldt, Terrible Perfection: Woinen and Russian Literature (Bloomington, Ind., 1987); G. L. Freeze, "Bringing Order to the Russian Family: Marriage and Divorce in Imperial Russia, 1760-1 860," Journal of Modern History 62 (December 1990): 709-46; G. G. Weickhardt, "Legal Rights of Women in Russia, 1100-1750," Slavic Review 55, 1 (Spring 1996): 1-23; N. L. Pushkareva, Zhenshchiny Rossii i Evropy na poroge novogo vremeni (Moscow, 1996). For more bibliography see Marsh, Women in Russia and Ukraine, 1-30, and Pushkareva, Zhenshchiny, 9-62. 
9. Pushkareva, Women in Russian History; Lotman, Besedy.

10. M. A. Anikst and V. S. Turchin, eds., ...v okrestnostiakh Moskvy. Iz istorii russkoi usadebnoi kul'tury XVII-XIX vekov / Country Estates Around Moscow (Moscow, 1979); P. Roosevelt, Life on the Russian Country Estate: A Social and Cultural History (New Haven, Conn., 1995).

11. According to the 1762 census, 51 percent of the nobles owned fewer than twenty-one serfs. See A. Kahan, "The Costs of 'Westernization' in Russia: The Gentry and the Economy in the Eighteenth Century," in The Structure of Russian History: Interpretive Essays, ed. M. Cherniavsky (New York, 1970), 227.

12. G. Hammarberg, "Flirting with Words: Domestic Albums, 1770-1840," in Goscilo and Holmgren, Russia, Women, Culture, 297-320.

13. M. Ledkovsky, Ch. Rosental, and M. Zirin, eds., Dictionary of Russian Women Writers (Westport, Conn./London, 1994), xxix.

14. Quoted in N. Kniazhnin, “Slovar' russkikh pisatel'nits (1759-1859)," Russkii arkhiv 3 (1865): $1389-481$.

15. See, for example, the first known memoirs by Natalia Dolgorukova (1767) in English translation: Ch. Townsend, ed. and trans., Memoirs of Princess Natalia Borisovna Dolgorukaya (Columbus, Ohio, 1977).

16. A. A. Grigor'ev, Iskusstvo inravstvennost' (Moscow, 1986), 155.

17. V. Dal', Tolkovyi slovar' zhivogo veligorusskogo iazyka, vol. 1 (St. Petersburg, 1903).

18. G. Fedotov, “Revoliutsiia idet," in Sud'ba i grekhi Rossii (St. Petersburg, 1991), 1: 159. Modern translations of the term illustrate that, following the fusion of rigid societal structures, it has lost its originally clear meaning. I have so far come across six versions of the title of Pushkin's "Baryshnia—krest'ianka": (1) "The Squire's Daughter," in Alexandr Pushkin, Complete Prose Fiction, trans. P. Debreczeny (Palo Alto, Calif., 1983); (2) "An Amateur Peasant Girl," in The Prose Tales of Alexandr Pushkin, trans. T. Keane (Freeport, N.Y., 1971); (3) "Mistress Into Maid," in The Works of Alexandr Pushkin: Lyrics, Narrative Poems, Folk Tales, Plays, Prose, ed. A. Yarmolinsky (New York, 1936); (4) "Peasant-Lady," in Alexandr Pushkin, The Tales of Belkin, trans. G. Aitken and D. Budgen (London, 1983); (5) "Mistress-Peasant Girl," in Alexandr Pushkin, Tales of the Late Ivan Petrovich Belkin, ed. N. Henley (Letchworth, Hertfordshire, 1965); (6) "Lady Into Lassie," in Alexandr Pushkin, Selected Works in Two Volumes (Moscow, 1974).

19. Here are several instances from literature: "But provincials are not in a hurry to seek enlightenment in the capital" (M. Lermontov, Tambovskaia kaznacheisha); "Her every move suggests provinciality right away" (A Pisemskii, Tiufiak); "All your people are an out-of-the-way province, something dull, boring, awkward; while those others are the real capital, luster and, festivity" (V. Stasov, “Dve khudozhestvennye vystavki”); “'Look, you piteous, hapless provincial,' I tried to admonish him, "here in Petersburg nobody gets out of bed before eleven"' (A. Kuprin, "Chernyi tuman"). 
21. "They find her odd-so unaffected, so country fied, a bit dejected" (A. Pushkin, Evgenii Onegin, trans. B. Deutsch); "Although dissatisfied with the weakness of her memory, Anna Vlassievna ascribed it to her provincial bashfulness" (A. Pushkin, "Kapitanskaia dochka," trans. $\mathrm{T}$. Keane); "She should be torn away from her family as soon as possible, before they succeed in spoiling her by vulgar upbringing. And when they make her a baryshnia, in the full sense of the word, it will be too late" (A. Ostrovskii, Dokhodnoe mesto); "She was querulous like a provincial baryshnia and easily wept over any disappointment” (N. Leskov, Zakhudalyi rod).

22. M. Kugler, "Provincial Intellectuals: Identity, Patriotism, and Enlightened Peripheries," The Eighteenth Century: Theory and Interpretation 37, 2 (Summer 1996): 158. According to Donald Raleigh, long-time disregard for local history by Soviet scholars was one of the causes of the recent crisis in the Russian science of history: D. J. Raleigh, "Nekotorye mysli o krisise v istoricheskoi nauke i ob izuchenii lokal'noi istorii," in Istoriia Rossii: Dialog rossiiskikh $i$ amerikanskikh istorikov (Saratov, 1994), 10-28.

23. The metaphor was suggested by Evgenii Anisimov. I express my gratitude to him for the useful discussion.

24. See examples in O. E. Glagoleva, Russkaia provintsial'naia starina: Ocherki kul'tury $i$ byta Tul'skoi gubernii XVIII-pervoi poloviny XIX vv. (Tula, 1993), 16-54. Compare to the Soviet tradition of laying out the best, if not the only, square in a town in front of the local Communist Party headquarters.

25. Quoted in Kugler, "Provincial Intellectuals", 159.

26. N. D. Chechulin, Russkoe provintsial'noe obshchestvo vtoroi poloviny XVIII veka (St. Petersburg, 1889).

27. A. N. Sevast'ianov, Rost obrazovatel'noi auditorii kak factor razvitiia knizhnogo $i$ zhurnal'nogo dela v Rossii (1762-1800) (Moscow, 1983).

28. G. Marker, Publishing, Printing, and the Origins of Intellectual Life in Russia, 17001800 (Princeton, N.J., 1985); M. Okenfuss, The Rise and Fall of Latin Humanism in EarlyModern Russia: Pagan Authors, Ukrainians, and the Resiliency of Muscovy (Leiden; N.Y., 1995); S. P. Luppov, Kniga v Rossii v pervoi chetverti XVIII veka (Leningrad, 1973), and Kniga v Rossii v poslepetrovskoe vremia: 1725-1740 (Leningrad, 1976); A. V. Blium, "Izdatel'skaia deiatel'nost' v russkoi provintsii kontsa XVIII-nachala XIX vv.," in Kniga. Issledovaniia $i$ materialy (Moscow, 1966), 12: 136-59; K. I. Abramov, Istoriia bibliotechnogo dela v SSSR (Moscow, 1980).

29. C. Lougee, Paradis de femmes: Women, Salons, and Social Stratification in SeventeenthCentury France (Princeton, N.J., 1976); L. Bernstein, "Women on the Verge of a New Language: Russian Salon Hostesses in the First Half of the Nineteenth Century," in Goscilo and Holmgren, Russia, Women, Culture, 209-24.

30. M. Aronson and S. Reiser, Literaturnye kruzhki i salony (Leningrad, 1929), 301-06. 
31. Chechulin, Russkoe provintsial'noe obshchestvo, 33. Compare with the description of the country nobility in M. V. Beer, "Semeinaia khronika Yelaginykh-Beer. Vospominaniia (18231870e gody)," Rossiiskaia Gosudarstvennaia Biblioteka, Otdel rukopisei (RGB OR), f. 99. 25. 19, 1. 7: "As to landowners in general, their main interest was agriculture and their conversations were primarily 'harvest-minded,' as my mother used to call them."

32. Chechulin, Russkoe provintsial'noe obshchestvo, 96. For the stereotype, see V. Zommer, "Krepostnoe pravo i dvorianskaia kul'tura v Rossii XVIII veka," in Itogi XVIII veka v Rossii. Vvedenie v russkuiu istoriiu XIX veka. Ocherki (Moscow, 1910), esp. 331-32, 352, 390, 407-11.

33. L. E. Klein, "Gender and the Public/Private Distinction in the Eighteenth Century: Some Questions About Evidence and Analytic Procedure," Eighteenth-Century Studies 29, no. 1 (1995): 104-05.

34. A History of Private Life, vol. 3, Passions of the Renaissance (Cambridge, Mass., 1989), 4-6.

35. Revealing enough is the fact that the Russian language has no adequate word for "privacy." Translations such as uedinenie, uedinennost' sekretnost'(The Oxford Russian Dictionary (Oxford, New York, 1997)), only loosely convey its meaning. In my opinion, this is a consequence of a communal mentality and collective style of social organization which consider the tendency to the private, and privacy, as an attempt to conceal something wrong or vicious. See the similar understanding in S. Boym, The Cominon Places: Mythologies of Everyday Life in Russia (Cambridge, 1994).

36. Pushkareva, Zhenshchiny Rossii, 87: Weickhardt, "Legal Rights of Women," 19. For good evidence on the active role of noblewomen in the rural economy, see the description of documents from the Bolotov family archive in E. Shchepkina, Starinnye pomeshchiki na sluzhbe i doma (I578-1762) (St. Petersburg, 1890), 22-27, 31-33, 37-38, etc.

37. This type of house, with only three rooms for both the family and domestic serfs, survived in the provinces well into the second half of the eighteenth century. See A. T. Bolotov's descriptions of several of his relatives' and neighbors' houses in Zhizn 'i prikliucheniia Andreia Bolotova, opisannye samim im dlia svoikh potomkov (1738-1793), 4 vols. (St. Petersburg, 1870-1873), 2: $304-06,475,514$, etc.

38. E. Levin, Sex and Society in the World of the Orthodox Slavs, 900-1700 (Ithaca, N.Y., 1989), 133 ff.; D. H. Kaiser, "The Public World of Private Life: Evidence on Spouse Relations in Seventeenth-Century Muscovy," paper presented at the conference, "Private Life in Russia: Medieval Times to the Present," Ann Arbor, Mich., 1996.

39. See N. A. Evsina, Arkhitekturnaia teoriia v Rossii vtoroi poloviny XVIII-nachala XIX veka (Moscow, 1985); Anikst and Turchin, ...v okrestnostiakh Moskvy; Roosevelt, Life on the Russian Country Estate.

40. L. Semenova, Ocherki istorii byta i kul'turnoi zhizni Rossii. Pervaia polovina XVIII v. (Leningrad, 1982), 118-19. 
41. I. Iurkin, Demidovy v Tule: iz istorii stanovleniia i razvitiia promyshlennoi dinastii (Tula, 1998), 110-13.

42. Compare these values with those of a "good" woman in Europe in the sixteenth century in S. F. Mattews Grieco, Ange ou diablesse (Paris, 1991), 392-93.

43. J. Tovrov, The Russian Noble Family: Structure and Change (New York, 1987), 290.

44. L. N. Vinogradova, "Devich'i gadaniia o zamuzhestve $v$ tsikle slavianskoi kalendarnoi obriadnosti (zapadno-vostochnoslavianskie paralleli)," in Slavianskii i balkanskii fol'klor. Obriad. Tekst (Moscow, 1981), 13-34.

45. W.F. Ryan and F. Wigzell, "Gullible Girls and Dreadful Dreams: Zhukovskii, Pushkin, and Popular Divination," Slavonic and East European Review 70, no. 4 (October 1992): 647-69.

46. A. K. Baiburin, Ritual v traditsionnoi kul'ture: Strukturno-semanticheskii analiz vostochnoslavianskikh obriadov (St. Petersburg, 1993), 67-79.

47. The girls' fear of remaining unmarried had a strong juridical basis in pre-Petrine laws: according to the 1649 Law Code, after a nobleman's death his unmarried daughter without brothers was eligible for her own maintenance allotment (prozhitok) until the age of fifteen. The allotment operated like a dowry. If not married by that age, she was, however, supposed to return this allotment. Thus, the law insisted on early marriages for noblewomen. Although abolished by Peter's decrees of 1714 and 1716, the provisions of the 1649 Law Code remained in the women's psychological memory for a long time thereafter. See Semenova, Ocherki, 43-49; Weickhardt, "Legal Rights of Women," 15-20. For examples of folk proverbs on the subject see Pushkareva, Zhenshchiny Rossii, 65 . See also the strong negative attitude toward unmarried girls in the midnineteenth century short story "Baryshnia" by Kniazhna - a in Nashi, spisannye s natury russkimi, ed. A. Ia. Isakov (St. Petersburg, 1841), 5: 33-40.

48. V. F. Ikonomov, Nakanune reform Petra Velikogo (Moscow, 1903). Wide archival evidence on domestic violence is presented in Kaiser, "The Public World of Private Life."

49. Freeze, "Bringing Order," 712-15.

50. Bolotov, Zhizn' i prikliucheniia, 1: 9; Shchepkina, Starinnye pomeshchiki, 29.

51. Bolotov, Zhizn' i prikliucheniia, 2: 757-58.

52. Biblioteka Rossiiskoi Akademii Nauk, Otdel rukopisei (OR BAN), f. 69, Bolotovy, d. 12, 1. $14 \mathrm{ob}$.

53. S. I. Kotkov, ed., Gramotki XVII-nachala XVIII veka (Moscow, 1969), 155, no. 290. Here and below the modern transcription of Russian texts is mine; while preserving the original spelling, I add punctuation marks in brackets and replace common abbreviations such as zсдрь, млстию, Хрсme, and бгу, with modern государь, милостию, Христе, and богу. Also, I replace letters that are no longer in use with their modern substitutes, or omit them, as required by modern orthography. "Государю моему Алексею Яковлевичю женишка твоя Фекла челом бет и 3 детишками твоими с Петром да Михаилом и аз в печалех своих в домишки своем в селце 
Коренкове чют в живе скитаюся[,] да кресянин наш Мишка ушел совсем из селца Коренкова[,] да как ты государь мои Алексеи Яковлевич изволишь про денги[,] что тебе государю моему понадобица денег[,] и ты как изволиш[,] я и шупку свою продать хочю или заложить или как ты государь мои изволиш[,] . . . а животинишки что есть и та помирает голодною смертию[,] . . . а крестьяне м[е]ня и люди и девки не слушают[,] только и люде[й] что Васка[,] а послала я тебе государю человека Васку[,] по том тебе посавыи женишка твоя Фекла челом бет. Отдать сея грамотка в городе Твери в сежеи избе Алексею Яковлевичю Спеву."

54. V. Narezhnyi, Rossiiskii Zhilblaz, ili Pokhozhdeniia kniazia Gavrily Simonovicha Chistiakova (1814), cited by E. Anisimov in Vremia petrovskikh reform (Leningrad, 1989), 315the episode is omitted in the English translation of this book, The Reforms of Peter the Great: Progress Through Coercion in Russia, trans. J. T. Alexander (Armonk, N.Y., 1993); N. S. Leskov, Zakhudalyi rod. Semeinaia khronika kniazei Protazanovykh, in N. S. Leskov, Sobranie sochinenii v 11 tomakh (Moscow, 1957), 5: 9.

55. Kotkov, Gramotki, 55, no. $84 ; 63$, no. 106; 75 , no. 132.

56. S. I. Kotkov and N. P. Pankratova, Istochniki po istorii russkogo narodno-razgovornogo iazyka XVII-nachala XVIII veka (Moscow, 1964), 32-33: "Государю моему Ивану Ивановичу[,] здравствуй государь мой Иван Иванович на многия лета[,] пожалуй государь мой прикажи ко мне писат про свое многолетное здарове[,] а мне сльша твое много летное здаровье о Христе радоватца и хвалу богу воздать[,] а про меня пожалуешь милостию своею напаметуешь[,] и я в печалех своих по нижеявленное число и с Марюшкою слава богу жива ... [T]ы извол ко мне отписат не помешкав[,] и за сем писанием жена твоя Маря кланеюсь из села Долбина февроля в 13 де[нь] 1716 годе."“

57. Ibid., 36: “Государю моему батюшку Ивану Ивановичу[,] здравие вашего да сохранит десница вышняго бога на лета многа[,] пожалуй государь мой батюшко извол ко мне писат про свое многолетное здравие и про здорове государыни моей матушке Маре Дмитревне ... При сем писава дач [sic] ваша Настася благословения прашу и кланяюс июля 11 де[нь]."

58. OR BAN, f. 69, d. 1, 1.31: “При сем и я вам батюшка любезной братец Павел Андреевич свидетельствую мое искреннее почитание ... Так же и я вам милостивая государыня матушка сестрица Лизавета Андреевна свидельствую мое искреннее почитание . . . ручки целую ..." Note the use of батюика and матушка as the forms of address indicating particular respect to the elder siblings.

59. M. Boitsov, ed., "K chesti Rossii." Iz chastnoi perepiski 1812 goda (Moscow, 1988), $47-48$.

60. Pushkareva, Women in Russian History, 155. As put in the introduction to Costlow et al., Sexuality, "Peter's reforms in this area [women's seclusion in the terem] have been little studied, despite the importance that he and his contemporaries granted them" (279).

61. Quoted in Anisimov, The Reforms of Peter the Great, 222. I have made some changes to the translation. 
62. Researchers usually refer to this decree's positive effects on women's position in society; its influence on morals has only been touched upon by L. Hughes in "Peter the Great's Two Weddings: Changing Images of Women in a Transitional Age," in Marsh, Women in Russia and Ukraine, 31-44.

63. N. I. Kostomarov, Ocherki domashnei zhizni i nravov velikorusskogo naroda v XVI $i$ XVII stoletiiakh (Moscow, 1992), 173, 175.

64. The Art of Costume in Russia, Eighteenth to Early Twentieth Century: The Hermitage (Leningrad, 1979), 4-5; A. Ribeiro, Dress in Eighteenth-Century Europe, 1715-1789 (London, 1984). For the best example see the portrait of Tsarevna Anna Petrovna, c. 1714-1715 by I. Nikitin from the collection of the Tret'iakov Gallery, Moscow.

65. V. I. Lebedev, ed., Reformy Petra I. Sbornik dokumentov (Moscow, 1937), 311.

66. The Art of Costume, 4-5; Ocherki russkoi kul'tury XVII veka (Moscow, 1979), 2: 9-10.

67. Shchepkina, Starinnye pomeshchiki, 46. Tradition required that a bride should get the best clothes her family could obtain and afford. Usually, both casual and formal clothes comprised the wardrobe.

68. Ibid., 66. Praskov'ia was A. T. Bolotov's sister.

69. Semenova, Ocherki, 149; D. Rovinskii, Russkie narodnye kartinki (St. Petersburg, 1900), 84-114.

70. Rovinskii, Russkie narodnye kartinki, 106-07; Y. Ovsyannikov, ed., The Lubok: Seventeenth to Eighteenth Century Russian Broadsides (Moscow, 1968), 62: “пригожа и румяна, как обезьяна; . . . ходит по-немецки, а говорит по-шведски.“

71. RGB OR, f. 99.25. 19, 11. 14-14 ob., 22 ob.

72. I. Nepliuev, Zapiski Ivana Ivanovicha Nepliueva (1893; reprint, Newtonville, Mass., 1974), hereafter cited in the text. About Neplivev, see the introduction by H. Leventer in Zapiski, $\mathrm{i}-\mathrm{xi}$, and the bibliographic references; also in Lotman, Besedy, 233-38.

73. About this see Shchepkina, Starinnye pomeshchiki.

74. [B]озложась на промысел Божий, выехал [я] из Глухова немедленно и путь продолжал с поспешностью, дабы узнать скорее мой жребий и успокоить страждущую жену мою, которая, самое малое время жив со мною, вверглась чрез меня, хотя и неповинно, чему сам Бог свидетель, в такое бедственное и неизвестное состояние."

75. On Bolotov, see Th. Newlin, "Rural Ruses: Illusion and Anxiety on the Russian Estate, 1775-1815," Slavic Review 57, no. 2 (Summer 1998): 295-319, and "The Return of the Russian Odysseus: Pastoral Dreams and Rude Awakenings," Russian Review 55, no. 3 (July 1996): 44874; O. E. Glagoleva, “A. T. Bolotov-uchenyi, pisatel', entsiklopedist,'Voprosy istorii, no. 11 (1988): 3-16; J. L. Rice, "The Bolotov Papers and Andrei Timofeevich Bolotov, Himself," Russian Review 35, no. 2 (April 1976): 125-54, and "The Memoirs of A. T. Bolotov and Russian Literary 
History," in Russian Literature in the Age of Catherine the Great, ed. A. G. Cross (Oxford, 1976), 17-43; M. Raeff, "Zhizn' i prikliucheniia Andreia Bolotova: Introduction," in A. T. Bolotov, Zhizn' i prikliucheniia Andreia Bolotova (1931; reprint, Newtonville, Mass., 1973), iii-vii. References in the text are to the 1870-1873 edition cited in n. 37.

76. “Ты у нас ... женишок теперь с именем, и такой, что как скоро узнают тебя короче все и о всех твоих качествах разнесется молва повсюду, то найдутся многие из девушек, которые не отрекутся за тебя выттить, и которых матери и отцы с радостию за тебя отдадут. Но для тебя-то не всякая годится, и потому-то нет нужды и спешить. О достатке я не говорю, продолжал он, достаток- последнее дело, и с ним многих невест найтить можно; а нужно, чтоб был человек и чтоб тебе весь свой век не с скотиною жить, а чтоб и другая-то половина имела сколько нибудь таких же склонностей и дарований, какие имеешь ты. Как например, была бы охотница до наук, или любила б, по крайней мере, читать книги и чтоб было тебе с кем промолвить слово.“

77. Black, Citizens for the Fatherland, 152-71; N. D. Chechulin, "Vospitanie i domashnee obuchenie v Rossii v XVIII v.," Dela i dni, no. 1 (1920): 96-112; no. 3 (1922): 32-46.

78. Black, Citizens for the Fatherland, 156-58; Tovrov, The Russian Noble Family, 162; Raeff, Origins, 134-35.

79. A. T. Bolotov, "Detskaia filosofiia, ili nravouchitel'nye razgovory mezhdu odnoiu gospozhoiu i ee det'mi," in Russkaia filosofiia vtoroi poloviny 18 veka. Khrestomatiia, ed. B. V. Emel'ianov (Sverdlovsk, 1990), 333-43.

80. “Я, полюбив ее с первого дня искреннею супружескою любовью, сколько ни старался к ней с своей стороны ласкаться, и как ни приискивал и ни употреблял все, что только мог, чем бы ее забавить, увеселить и к себе теснее прилепить можно было; но успех имел в том очень малый. Она казалась иметь характер самый хладнокровнейший, и ко всему тому нимало нечувствительную. . . . Но что всего важнее, то и к самому себе не мог я от ней малейших взаимных и таких ласк и приветливости, какия обыкновенно молодыя жены оказывают и при людях и без них, мужьям своим. Нет, сего удовольствия не имел я в жизни!"

81. Bolotov founded and managed a pension for his own and other noblemen's children in Bogoroditsk; see details in Glagoleva, "A. T. Bolotov-uchenyi."

82. Institut Russkoi Literatury (Pushkinskii Dom), Otdel Rukopisei (OR IRLI), f. 537, d. 40, 1.13 .

83. "Iz dnevnika Pavla Bolotova za 1789 g.," in Muzyka i inuzykal'nyi byt staroi Rossii (Leningrad, 1927), 1:201-12.

84. A. T. Bolotov, "Sovremennik, ili Zapiski dlia potomstva. 1795," in Literaturnoe nasledstvo. XVIII vek (Moscow-Leningrad, 1933), 9-10: 176. On the book trade, see Marker, Publishing, Printing.

85. Quoted in A. V. Blium, ed., Ocharovannye knigoi (Moscow, 1982), 33-34. 
86. A. T. Bolotov, "Mysli i bespristrastnye suzhdeniia o romanakh," in Literaturnoe nasledstvo, 9-10: 210. For more details see: O. E. Glagoleva, "A. T. Bolotov kak chitatel"," in Rukopisnaia i pechatnaia kniga v Rossii. Problemy sozdaniia $i$ rasprostraneniia (Leningrad, 1988), 140-58, and "Biblioteka A. T. Bolotova," in Kniga v Rossii. XVI-seredina XIX v. Knigorasprostranenie, biblioteki, chitatel' (Leningrad, 1987), 79-95.

87. E. P. Privalova, "A. T. Bolotov i teatr dlia detei," in XVIII vek. vol. 3 (Moscow-Leningrad, 1958), 242-61; F. Setin, “Detskii teatr Andreia Bolotova (1738-1833)," Teatr, no. 9(1973): 55-57.

88. A. T. Bolotov, Izbrannoe, ed. A. K. Demikhovskii (Pskov, 1993), 50.

89. Ibid., 68: "Тут-то они меня узнают-благо и кстати будет перед невестою оказать свое искусство. Но что, однако--она дура! И не поймет, небось, того. Жениться-то на ней разве только для того, чтоб деревеньки-то поприбрать в руки и тестя-то дурака обалахтать! А денег-то у него, сказывают, с три бездны-все наши будуг. Тут-то пощеголять и повеселиться! Молодцу какая нужда в том, что она дурна и глупа! Девка-то и у ней не хуже почти Марфутки, а посмотря-поглядя можно и Марфутку-то подшибизить, великая диковинка!“

90. Ibid., 90, 94-97, 109.

91. Bolotov, "Detskaia filosofiia," 335.

92. “Что касается до обеих замужних дочерей моих, то большая из них Елизавета продолжала жить с мужем своим порядочно и по наружности счастливо и хорошо, но душеєно не мало огорчалась от его не совсем кротким, а временем строптивым нравом, а того более его ветреностью и излишнею наклонностию к пышности, мотовству и расточительности, угрожающей весьма худыми следствиями в разсуждение их достатка. Впрочем, она радовалась, чтө сей год не была беременна. У них был в живых один только сын Николай, живший от рождения у нас и нами воспитываемый. Он составлял тогда ежедневно нашу куклу, нашу забаву, нашу игрушку и наше увеселение. . . Д Другая моя замужняя дочь Настасья была уже около сего времени на сносях беременною и жила с мужем своим хотя не так пышно, но спокойнее и тише; обеспокоивалась только несколько расстроенными их обстоятельствами и состоянием и угнетающим их небольшим хотя долгом."

93. J. C. Zasek, introduction to Vospominaniia Anny Evdokimovny Labzinoi, 1758-1828, by A. Labzina (1914; reprint, Newtonville, Mass., 1974), i; Lotman, Besedy, 301. See also M. Zirin, "Labzina," in Dictionary of Russian Women Writers, ed. M. Ledkovsky, Ch. Rosenthal, M. Zirin (Westport, Conn., 1994), 355-56; and B. A. Engel, Mothers and Daughters (Cambridge, Mass., 1983), 14-16. Further references to Labzina, Vospominaniia, are given in the text.

94. For more on traditional upbringing, see A. B. Wachtel, The Battle for Childhood: Creation of a Russian Myth (Palo Alto, Calif., 1990).

95. M. Kamenskaia, Zabytaia kniga. Vospominaniia (Moscow, 1991), 271-75.

96. “Наконец, он, по делам, препорученным от начальства, принужден был чаще быть дома; но всегда был скучен. Сколько я ему ни говорила, что неужто я не могу усладить его жизни, и разве ему приятнее быть с чужими, он отвечал: 'Разве ты думаешь, что я могу тебя 
променять на тех девок, о которых ты говоришь? Ты всегда моя жена и друг, а это-только для препровождения времени и для удовольствия.' ' . . . но это выходит-скотство и грех перед Богом и нарушение тех клятв, которые ты давал мне перед евангелием! Остерегайся, мой друг, чтоб правосудие божие не постигло тебя!' Он засмеялся и сказал: 'Как ты мила тогда, когда начнешь философствовать! Тебя уверяіо, что ты называешь грехом то, что только есть наслаждение натуральное, и я не подвержен никакому ответу.'“

97. See J. Vowles, "Marriage à la russe," and the introduction to Costlow et al., Sexuality, 4$8,53-72$.

98. D. N. Begichev, Semeistvo Kholmskikh. Nekotorye cherty nravov i obraza zhizni, semeinoi i odinokoi, Russkikh dvorian, 6 vols. (Moscow, 1833), 4: 88.

99. Levin, Sex and Society, and "Sexual Vocabulary in Medieval Russia," in Costlow et al., Sexuality, 41-52; J. V. Brown, "Female Sexuality and Madness in Russian Culture: Traditional Values and Psychiatric Theory," Social Research 53, no. 2 (Summer 1986): 369-85.

100. Lotman, Besedy, 309.

101. In many of his writings, Bolotov tirelessly underlined his high moral principles and model conduct. One of the many examples is his emphasis on his good relations with landlords when in billets in the military. He describes them as nearly sycophantic in their gratitude for his not seeking the attentions of their unmarried daughters (Bolotov, Zhizn' i prikliucheniia, 1: 68893, 2: 140-41).

102. A. T. Bolotov, "O proiskhozhdenii chelovecheskogo roda $i$ o drugikh vazhnykh obstoiatel 'stvakh do nego otnosiashchikhsia. Razgovory u starika s ego vnukom," OR IRLI, f. 537, no. 23, 1. 5: "Многие люди рождаются без установленного богом бракосочетания, и от непотребных женщин, приживающих детей незаконным образом, и . . . при таких случаях богу никак неприлично содействовать созиданию новых тварей."

103. Semenova, Ocherki, 122.

104. For more examples, see Roosevelt, Life on the Russian Country Estate, 183-91.

105. P. B[artenev], "Avdot'ia Petrovna Yelagina. Nekrolog," Russkii arkhiv 15, p. 2(1877): 483-95; A. P. Zontag, "Vospominaniia o detstve V. A. Zhukovskogo," Russkaia mysl' 2 (1883): $267-84$.

106. Natal'ia had, besides her lawful daughter Anna, two daughters by Krechetnikov, Mariia and Avdot'ia; Varvara raised, besides her own four daughters, her husband P. Iushkov's natural son, A. Peterson; Ekaterina (1770-1848) brought up her two lawful children, Mariia and Aleksandra, and her husband A. Protasov's natural children V. Azbukin, N. Azbukina, and V. Protashinskii. One of Varvara's daughters, Ekaterina Iushkova, even married V. Azbukin.

107. “[Н]асмотрелся я довольно сей госпоже, игравшей тогда важную роль, и не мог довольно начудиться ее мужу, не чувствующему ни малейшего оттого стыда, что носил ночти только звание мужа, и жертвующему женою своею в угодность сему вельможе. Но 
не столько удивителен был мне он, сколько отец сей госпожи. Он был г. Бунин и служил тогда городничим в городе Белеве, где наместник и познакомился с сим семейством. Говорили, что будто бы и сам отец и мать сей госпожи, бывшей тогда девушкою, поспешествовали сами такому знакомству дочери своей с наместником, и единственно для того, чтоб пользоваться его милостью. И дабы можно было ему ее иметь всегда у себя в близости, то и выдана она была за молодого человека, из фамилии Вельяминовых, которого наместник по самому сему случаю произвел в люди и который, находясь при нем в должности советника правления, играл также тогда важную роль."

108. Gosudarstvennyi arkhiv Tul'skoi oblasti (GATO), f. 39, op. 2, d. 2705, 1. 82; M. Gershenzon, Obrazy proshlogo (Moscow, 1912), 90.

109. A. E. Gruzinskii', ed., Utkinskii sbornik. I: Pis'ma V. A. Zhukovskogo, M. A. Moier i E. A. Protasovoi (Moscow, 1904), 131. Hereafter cited in the text.

110. Glagoleva, Russkaia provintsial'naia starina, 55-66.

111. N. Tarasov, "Iz istorii tul'skogo teatra," in Tul'skii al'manakh, vol. 1 (Tula, 1948), 195.

112. Rossiiskaia Natsional'naia Biblioteka, Otdel rukopisei, f. 89, Bolotovy, d. 111, 1. 28 ob.: A. T. Bolotov's son Pavel wrote from Tula in a 1796 letter to his father: "Instead of the usual time for theater, I stayed most of the yesterday evening with my kind ... supervisor and spent not less pleasant time talking to him."

113. B[artenev], “Avdot'ia Petrovna Yelagina," 483.

114. GATO, f. 54, dop. op. 11, d. 91 ; f. 51, op. 1, t. 1, d. 462, 463.

115. Quoted in V. Vlasov and I. Nasarenko, "Minuvshikh dnei ocharovan'e" (Tula, 1983), $37-38$.

116. Zontag, "Vospominaniia", 267.

117. Russkii arkhiv 14, p. 3 (1876): 159.

118. Quoted in G. N. Parilova and A. D. Soimonov, "P. V. Kireevskii i sobrannye im pesni," Literaturnoe nasledstvo (Moscow, 1968), 79: 13: “Мы живем по-прежнему в четырех стенах: ездим из Мишенского в Долбино, из Долбина в Мишенское, из Мишенского в Игнатьево, из Игнатьева в Мишенское, из Долбина в Володьково, из Володькова в Долбино, из Долбина в Чернь, из Черни домой и прочие подобные неистовства, что мы точно так же носимся на тех же ногах, на которых и при вас носились."

119. Russkii biograficheskii slovar', (reprint, New York, 1962), vol. Plavil'shchikov-Primo, 94.

120. Tolychova, "Rasskazy i anekdoty," Russkii arkhiv 15, p. 2(1877): 366-68. 
121. N. V. Solov'ev, Istoriia odnoi zhizni. A. A. Voeikova- "Svetlana," 2 vols. (Petrograd, 1915-1916), 1: 21: “Скорей, скорей в дорогу, / В Муратово село. / Там счастье завело / Колонию веселья; / Там дни быстрей бегут / Меж дела и безделья!"

122. K. Zeidlits, Zhizn' i poeziia V. A. Zhukovskogo. 1783-1852. Po neizdannym istochnikam ilichnym vospominaniiam (St. Petersburg, 1883), 30.

123. V. A. Zhukovsky, "Iz dnevnikov 1827-1840 godov," Nashe nasledie, no. 32 (1994): 38. Here and in all quotations by Zhukovsky and the Bunin girls, emphases are in the originals.

124. Original in German. Quoted in Solov'ev, Istoriia, 1: 14.

125. Quoted in Vlasov and Nasarenko, "Minuvshikh dnei," 54.

126. Ibid., 55 .

127. For more information see V. V. Afanas'ev, Zhizn' i lira (Moscow, 1977); M. Ia. Bessarab, Zhukovsky. Kniga o velikom russkoin poete (Moscow, 1975); A. N. Veselovskii, V. A. Zhukovsky. Poeziia chuvstva $i$ "serdechnogo voobrazheniia" (Petrograd, 1918).

128. Original in French. Quoted in Solov'ev, Istoriia, 1: 12.

129. On this see Iu. M. Lotman, Sotvorenie Karamzina (Moscow, 1987), 265-77.

130. Hammarberg, "Flirting with Words," 305-06.

131. Original in German. Quoted in Solov'ev, Istoriia, 1: 11.

132. For more information, see her correspondence in Gruzinskii, Utkinskii sbornik, and P. N. Sakulin, M. A. Protasova-Moier po ee pis'mam (St. Petersburg, 1907).

133. Original in Russian and French. Solov'ev, Istoriia, 2: 67.

134. Gershenzon, Obrazy proshlogo; V. Liaskovskii, Brat'ia Kireevskie (St. Petersburg, 1899).

135. A. Peterson, "Cherty starinnogo dvorianskogo byta," Russkii arkhiv 15, p. 2 (1877): $479-81$.

136. M. Lermontov, Major Poetical Works, trans. A. Liberman (Minneapolis, 1983), 147: "И предков нам смешны роскошные забавы, / Их добросовестный ребяческий разврат."

137. Lotman, Besedy, 65-72.

138. I. M. Dolgorukii, "Slavny bubny za gorami, ili Puteshestvie moe koe-kuda v 1810 g.," Chteniia Obshchestva istorii i drevnostei Rossiiskikh, vol. 3 (1869): 333-34.

139. L. Bernstein, "Women on the Verge of a New Language: Russian Salon Hostesses in the First Half of the Nineteenth Century," in Goscilo and Holmgren, Russia, Women, Culture, 209-24; 
Aronson and Reisner, Literaturnye kruzhki i salony, 326-31; K. D. Kavelin, "Avdot'ia Petrovna Yelagina" (1899), reprinted in Russkoe obshchestvo 30-kh godov XIX veka. Liudi i idei. Memuary sovremennikov (Moscow, 1989), 135-47.

140. Russkii biograficheskii slovar', vol. Zhabokritskii-Zialovskii, 454-55.

141. Ibid., 455 .

142. On domestic tasks, see D. Goldstein, "Domestic Porkbarreling in Nineteenth-Century Russia, or Who Holds the Keys to the Larder?" in Goscilo and Holmgren, Russia, Women, Culture, $125-51$.

143. W. Rosslyn, "Conflicts Over Gender and Status in Early Nineteenth-Century Russian Literature: The Case of Anna Bunina and her Poem 'Padenie Faetona', " in Gender and Russian Literature: New Perspectives, ed. R. Marsh (Cambridge, 1996), 55-74; M. Fainshtein, Pisatel'nitsy pushkinskoi pory: Istoriko-literaturnye ocherki (Leningrad, 1989).

144. A.P. Zontag, "Pis'ma," in Otchet Imperatorskoi Publichnoi Biblioteki za $1893 \operatorname{god}$ (St. Petersburg, 1896), 139. Hereafter cited in text.

145. Quoted in Russkii biograficheskii slovar', vol. Zhabokritskii-Zialovskii, 454.

146. See Freeze, "Bringing Order."

147. RGB OR, f. 99. 25. 19. Further references to this manuscript are given in the text.

148. Ocherki istorii shkoly i pedagogicheskoi mysli narodov SSSR. XVIII-pervaia polovina XIX v. (Moscow, 1973), 255-69.

149. D. N. Begichev, Ol'ga, 4 vols. (St. Petersburg, 1840); Leskov, Zakhudalyi rod. Compare with S. Khvoshchinskaia, "Reminiscences of Institute Life," in Russia Through Women's Eyes: Autobiographies from Tsarist Russia, ed. T. W. Clyman and J. Vowles (New Haven, Conn., 1996).

150. Leskov, Zakhudalyi rod, 73.

151. Compare with N. Sokhanskaia, "Autobiography," in Clyman and Vowles, Russia Through Wornen's Eyes.

152. Quoted in Lotman, Besedy, 104: “Жена была на бале, я за нею поехал一и увез к себе, как улан уездную барышню с именин городничихи."

153. Glagoleva, Russkaia provintsial'naia starina, 110-12.

154. Begichev, Semeistvo Kholmskikh, 1: vi. Hereafter cited in the text.

155. Boym, Common Places, 49.

156. Ol'ga. Byt Russkikh dvorian v nachale nyneshnego stoletiia, 4 vols, (St. Petersburg, 1840). Hereafter cited in the text. 
157. I. S. Turgenev, “Asia,” in I. S. Turgenev, Dvorianskoe gnezdo. Rasskazy. Povesti. Roman (Tula, 1980), 82.

158. Bernstein, "Women on the Verge," 214.

159. Quoted in N. D. Kochetkova, "Geroi russkogo sentimentalizma: 1. Chtenie v zhizni 'chuvstvite l'nogo' geroia," in XVIII vek, vol. 14: Russkaia literatura XVIII-nachala XIX veka v obshchestvenno-kul'turnom kontekste (Leningrad, 1983), 125-26.

160. Okenfuss, The Rise and Fall of Latin Humanism, 194.

161. Quoted in Blium, Ocharovannye knigoi, 27,28.

162. Marker, Publishing, Printing, 97.

163. I. S. Kon, The Sexual Revolution in Russia: From the Age of the Czars to Today, trans. J. Riordan (New York, 1995), 25. It is noteworthy that in the Soviet era Kon was virtually the only person officially allowed to write on the taboo topic-sexuality.

164. Gruzinskii, Utkinskii sbornik, 65 .

165. Ibid., 66 .

166. M. N. Murav'ev, "Pis'ma ottsu i sestre 1777-1778 godov," ed. L. I. Kulakova and V. A. Zapadov, in Pis'ma russkikh pisatelei XVIII veka (Leningrad, 1980), 259-377. Hereafter cited in the text.

167. E. I. Raevskaia, "Khroniki," Gosudarstvennyi Literaturnyi Muzei, Otdel rukopisei, f. 155, OF 2881, Il. 62-62 ob.

168. RGB OR, f. 99.25. 19, 1.24 ob.

169. For more details see O. E. Glagoleva, Tul'skaia knizhnaia starina. Ocherki kul'turnoi zhizni XVIII-pervoi poloviny XIX vv. (Tula, 1992), 49-113, and Russkaia provintsial'naia starina, 81-116, 163-86.

170. Quoted in Lotman, Besedy, 58.

171. Leskov, Zakhudalyi rod, 114: “там, за стенами дома, катилась и гремела другая жизнь, новая, оторванная от домашннх преданий: люди иные, на которых страна смотрела еще как удивленная курица смотрит на выведенных ею утят." 